\title{
Late Quaternary marine ostracods of the Basque Basin (S Bay of Biscay): taxonomy and distribution
}

\author{
Julio RODRÍGUEZ-LÁZARO ${ }^{*}$, Blanca MARTÍNEZ-GARCÍA ${ }^{2}$, Maite MARTÍN-RUBIO , \\ Ana PASCUAL ${ }^{1}$ \& Zeltia VARELA ${ }^{1}$
}

\footnotetext{
${ }^{1}$ Department of Stratigraphy and Palaeontology, Faculty of Science and Technology, University of the Basque Country UPV/ EHU, Box 644, 48080 Bilbao, Spain; julio.rodriguez@ehu.eus; ana.pascual@ehu.eus; zeltia.varela@ehu.eus

${ }^{2}$ Paseo Ramón Pelayo 12, 19, 39710 Solares, Cantabria, Spain; blancamaria.martinez@ehu.eus

${ }^{3}$ Department of Mining \& Metallurgical Engineering and Materials Science, Faculty of Engineering of Bilbao, University of the Basque Country UPV/EHU, Paseo Rafael Moreno Pitxitxi, 3, 48013 Bilbao, Spain; maite.martin@ehu.eus

* Corresponding author
}

Rodríguez-Lázaro, J., Martínez-García, B., Martín-Rubio, M., Pascual, A. \& Varela, Z. 2018. Late Quaternary marine ostracods of the Basque Basin (S Bay of Biscay): taxonomy and distribution. [Ostrácodos marinos del Cuaternario final en la Cuenca Vasca (S Golfo de Vizcaya): taxonomía y distribución]. Spanish Journal of Palaeontology, 33 (1), $139-184$.

\begin{abstract}
Late Quaternary taxonomy and ecologic and age distributions of ostracods from the Basque Basin (S Bay of Biscay) are described. More than forty-four thousands ostracod specimens have been obtained from one hundred surface samples and core samples from six cores located in shelf and upper bathyal depths and other infrabathyal core as comparative deep reference. A total of 155 species have been taxonomically described, belonging to 67 genera. Most characteristic species (123) have been SEM figured, and ecologic-geographic distributions and ages have been provided for all species. The resulting database will be a useful help for palaeoceanographic and palaeoclimatologic studies of the region.
\end{abstract}

Keywords: Ostracod taxonomy, distribution, Late Quaternary, Basque Basin, Bay of Biscay.

\section{RESUMEN}

En este trabajo se describen la taxonomía y las distribuciones ecológicas y de edad de los ostrácodos del Cuaternario final en la Cuenca Vasca (S Golfo de Vizcaya). Más de cuarenta y cuatro mil especímenes han sido obtenidos de un centenar de muestras superficiales, así como de un total de seis sondeos localizados en la plataforma y talud superior y otro sondeo infrabatial como material de comparación. Un total de 155 especies, incluidas en 67 géneros, han sido caracterizadas taxonómicamente. Las especies más importantes (123) han sido fotografiadas con MEB y se describen las distribuciones ecológicas y temporales de la totalidad de las especies. La base de datos resultante constituye una herramienta muy útil para estudios posteriores de la palaeoceanografía y paleoclimatología de esta región.

Palabras clave: Taxonomía de ostrácodos, distribución, Cuaternario final, cuenca Vasca, Golfo de Vizcaya. 


\section{INTRODUCTION}

Quaternary palaeoceanographic and palaeoclimatic research of the $\mathrm{N}$ Atlantic included ostracod assemblages as useful indicators of major environmental changes (Cronin et al., 1999, 2002; Horne et al., 2012) and deep NE Atlantic modern ostracods have been described from several basins (Coles et al., 1996; Didié \& Bauch, 2000; Alvarez Zarikian, 2009; Yasuhara et al., 2009; Yasuhara \& Okahashi, 2015).

Previous studies on ostracods in the Bay of Biscay have considered modern bathymetric distributions in the northern Aquitanian margin (Caralp et al., 1968; Peypouquet, 1970; Carbonel, 1971, 1973; Guillaume et al., 1985). Coastal ( $<50 \mathrm{mwd})$ assemblages are characterised by Palmoconcha guttata (Norman), Cytheromorpha robertsononi (Brady), Leptocythere pellucida (Baird), Semicytherura sella (Sars) and Semicytherura acuticostata (Sars). Marine shelf (50-200 mwd) assemblages contain as major species Carinocythereis carinata (Roemer), Pterygocythereis jonesii (Baird), Bosquetina dentata (Müller) and species of the genus Cytheropteron. In the upper talus a new assemblage is found with Cytheropteron rotundatum Müller, Cytheropteron alatum Sars, Argilloecia conoidea (Sars) and Henryhowella asperrima (Reuss).

Deeper bathyal and abyssal waters are poorly represented by ostracods with Cytherella lata Brady, Cytheropteron testudo Sars, Echinocythereis echinata (Sars), Buntonia corpulenta (Brady \& Norman) and juveniles of genus Krithe. In particular, a glacial preHolocene assemblage was described for the Capbreton Canyon area, with Heterocyprideis sorbyana (Jones), Elofsonella concinna (Jones), Finmarchinella finmarchica (Sars), Eucytheridea bairdii (Sars) and Bythocythere constricta Sars (Peypouquet, 1970).

In the Basque shelf, located in the southern Bay of Biscay, modern distributions of ostracods and foraminifers have been described taking into account the most representative species (Pascual et al., 2008; Martínez-García, 2012). Quaternary oceanographic and climatic changes in this basin have been described considering the type of assemblages and the occurrence of indicative "Northern guest" species (Martínez-García, 2012; Martínez-García et al., 2015). Other studies with ostracods in this region are mostly referring to transitional-estuarine areas in the Basque Country coasts (Rodríguez-Lázaro \& Pascual, 1985; Pascual, 1990a, 1990b, 1991; Pascual \& Carbonel, 1992; Pascual et al., 1998, 2002) and Cantabria coast (Martín Rubio et al., 2004, 2006; Martínez García et al., 2013).

In a current research on the chronology, isotopic geochemistry and faunal distributions (foraminifers and ostracods; Rodríguez-Lázaro et al., 2009, 2011, 2017), the ostracods are used to describe the palaeoenvironmental evolution of the southern region of Bay of Biscay during the late Quaternary.
Despite all these references, no synthetic work considering all the ostracod assemblages of the Basque Basin has been published to date. In this paper we describe by the first time the Late Quaternary ostracods from the Basque shelf areas and upper talus, providing with SEM pictures of most of the species as well as the stratigraphic and areal-ecologic distributions. This database will be a useful tool to further studies of the palaeoceanography and palaeoclimatology of this region.

\section{MATERIAL AND METHODS}

More than forty-four thousands ostracod specimens have been obtained for this work. Samples have been collected in surface sediments, five cores located in the southern margin of Capbreton Canyon (KS05-05, KS0510, KS04-16, KS-16, KS-21), one core in the northern margin Oxybent-D), and another deep core (PP10-17), representative of deep Atlantic ostracods (Fig. 1). Data of cores and samples are indicated in Table 1. MartínezGarcía (2012) found ostracods in 89 surface samples (42 samples with $>100$ ind.), recording a total of 6026 valves belonging to 151 species ( 24 major, 28 secondary, 99 accessory) and studied in detail 47 species (28 genera). Modern assemblages are poorly represented by biocenoses $(<1 \%$ of total ostracods) and more abundant species are C. edwardsii, P. guttata, Pterygocythereis ceratoptera (Bosquet) and P. jonesii (Martínez-García, 2012). The stratigraphic range of studied cores is from MIS5 to the Recent (Fig. 2).

All studied samples and specimens are stocked at the Palaeontology laboratory of the University of the Basque Country UPV/EHU.

\section{SYSTEMATIC PALAEONTOLOGY}

Described for each species: synonymy with known age and palaeoecology. Distribution in the Basque Basin and/ or Bay of Biscay is indicated. As references for higher classification scheme we used Kempf (1986, 1987, 1988 and later supplements), Athersuch et al. (1989), Horne et al. (2002), World Ostracoda Database (Brandão et al., 2017).

Class OSTRACODA Latreille, 1802

Subclass MYODOCOPA Sars, 1866

Order HALOCYPRIDA Dana, 1853

Suborder CLADOCOPINA Sars, 1866

Superfamily CLADOCOPOIDEA Sars, 1866 


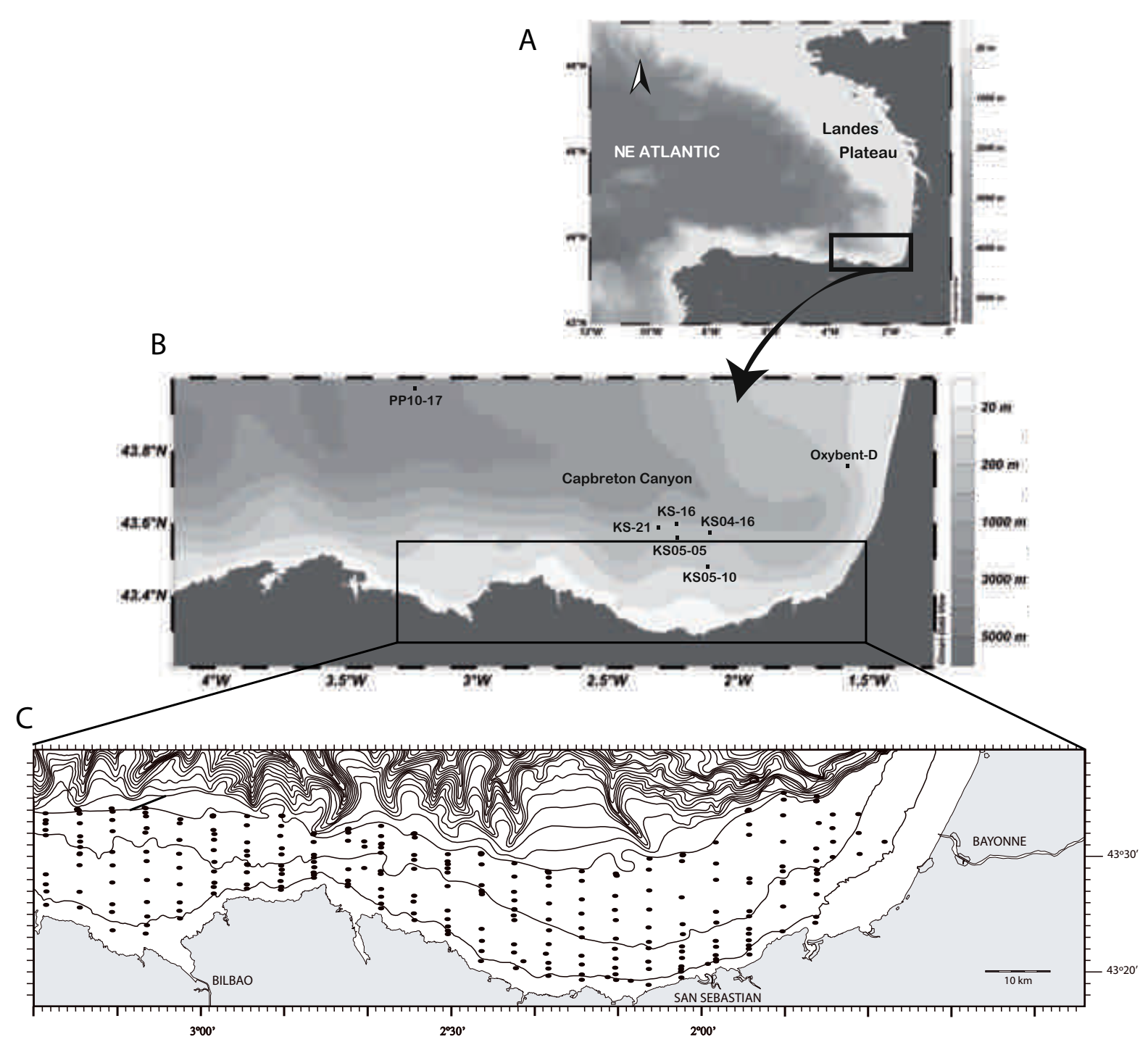

Figure 1. a-b) locations of studied cores in the S Bay of Biscay. KS- are cores, with detailed data indicated in Table 1. c) Location of surface samples in the Basque shelf. Map from Ocean Data View (http://odv.awi.de; Schlitzer, 2016).

Family Polycopidae Sars, 1866

Genus Polycope Sars, 1866

Type species Polycope orbicularis Sars, 1866

Polycope frequens G.W. Müller, 1894 sensu Bonaduce et al., 1976

(Fig. 3a)

1976 Polycope frequens; Bonaduce, Ciampo \& Masoli, pl. 2, fig. 5. (Recent Adriatic Sea, in waters deeper than $110 \mathrm{~m}$.).

1976 Polycope frequens?, Breman, pl. 5, fig. 52. (Recent Adriatic Sea).
Distribution. This species is very rare in the Recent Basque shelf.

\section{Polycope cf. reticulata G.W. Müller, 1894}

(Fig. 3b)

Remarks. This species is morphologically close to Polycope reticulata G.W. Müller, 1894, in Uffenorde (1972) of Recent Adriatic Sea.

Distribution. Scarcely found in Early Holocene to Recent in the Basque shelf. Also present in MIS2, MIS3 of bathyal S Bay of Biscay.

Subclass PODOCOPA Sars, 1866

Order PLATYCOPIDA Sars, 1866 
Table 1. Locations and other data of studied cores and samples.

\begin{tabular}{|c|c|c|c|c|c|c|c|c|}
\hline Core & Type & Cruise & Year & Latitude & Longitude & $\begin{array}{l}\text { Depth } \\
\text { (m) }\end{array}$ & $\begin{array}{l}\text { Length } \\
\text { (cm) }\end{array}$ & Reference \\
\hline KS05-05 & Kullenberg & Euska-3 & 2005 & $43^{\circ} 30^{\prime} 597 \mathrm{~N}$ & $2^{\circ} 13^{\prime} 760 \mathrm{~W}$ & 259 & 255 & $\begin{array}{l}\text { University of } \\
\text { Bordeaux } 1\end{array}$ \\
\hline KS05-10 & Kullenberg & Euska-3 & 2005 & $43^{\circ} 22^{\prime} 765 \mathrm{~N}$ & $2^{\circ} 06^{\prime} 744 \mathrm{~W}$ & 114 & 254 & $\begin{array}{l}\text { University of } \\
\text { Bordeaux } 1\end{array}$ \\
\hline KS04-16 & Kullenberg & Euska-2 & 2004 & $43^{\circ} 32^{\prime} 66 \mathrm{~N}$ & $2^{\circ} 05^{\prime} 72 \mathrm{~W}$ & 294 & 128 & $\begin{array}{l}\text { University of } \\
\text { Bordeaux } 1\end{array}$ \\
\hline KS-16 & Kullenberg & Prosecan 4 & 2007 & $43^{\circ} 35^{\prime} 08 \mathrm{~N}$ & $2^{\circ} 16^{\prime} 31 \mathrm{~W}$ & 483 & 290 & $\begin{array}{l}\text { University of } \\
\text { Bordeaux } 1\end{array}$ \\
\hline KS-21 & Kullenberg & Prosecan 4 & 2007 & $43^{\circ} 34^{\prime} 22 \mathrm{~N}$ & $2^{\circ} 18^{\prime} 23 \mathrm{~W}$ & 460 & 330 & $\begin{array}{l}\text { University of } \\
\text { Bordeaux } 1\end{array}$ \\
\hline PP10-17 & Piston core & Sargass & 2010 & $43^{\circ} 58.91 \mathrm{~N}$ & $3^{\circ} 14.02 \mathrm{~W}$ & 2880 & 1792 & $\begin{array}{l}\text { Brocheray et } \\
\text { al. (2014) }\end{array}$ \\
\hline Oxybent-D & Multi-corer & Oxybent & $1998-2000$ & $43^{\circ} 43^{\prime} 19.1{ }^{\prime \prime} \mathrm{N}$ & $1^{\circ} 33^{\prime} 25.2 » \mathrm{~W}$ & 150 & $\begin{array}{l}20 \mathrm{~cm} \mathrm{x} \\
8 \text { cores }\end{array}$ & $\begin{array}{l}\text { Carbonel } \\
\text { (1997) }\end{array}$ \\
\hline $\begin{array}{l}\text { Surface } \\
\text { samples }\end{array}$ & $\begin{array}{l}\text { Schipeck/ } \\
\text { Eckman }\end{array}$ & Euskased & 2003 & $\begin{array}{l}43^{\circ} 18^{\prime} 942 \text { and } \\
43^{\circ} 35^{\prime} 196 \mathrm{~N}\end{array}$ & $\begin{array}{l}1^{\circ} 40^{\prime} 848 \text { and } \\
3^{\circ} 18^{\prime} 078 \mathrm{~W}\end{array}$ & $\begin{array}{l}42.8 \text { to } \\
156\end{array}$ & -- & $\begin{array}{l}\text { University of } \\
\text { Bordeaux } 1\end{array}$ \\
\hline
\end{tabular}

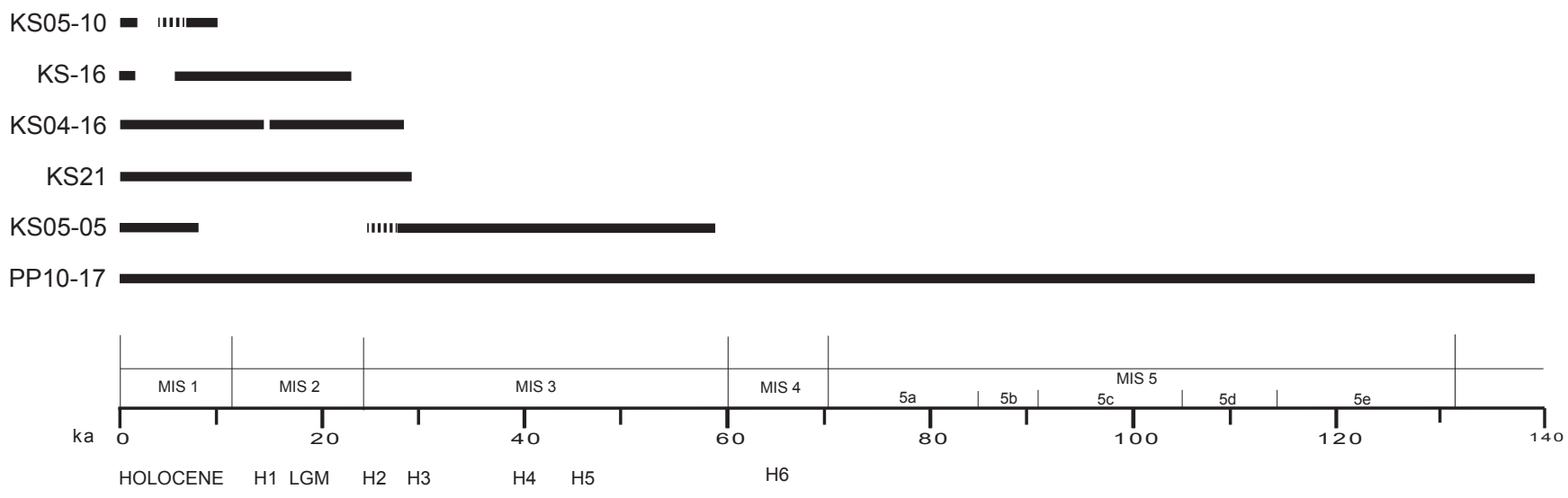

Figure 2. Stratigraphic ranges of the studied cores. Some events are indicated: LGM: Last Glacial Maximum; H: Heinrich event.

Suborder PLATYCOPINA Sars, 1866

Superfamily CYTHERELLOIDEA Sars, 1866

Family Cytherellidae Sars, 1866

Genus Cytherella Jones, 1849

Type species Cytherella ovata (Roemer, 1841)

Cytherella alvearium Bonaduce, Ciampo \& Masoli, 1976

(Fig. 3c)

1979 Cytherella alvearium; Yassini, pl. 1, figs 8, 10.

(Recent, Algerian coastal bay).
1976 Cytherella alvearium; Bonaduce et al., p. 20, pl. 4, figs 5-8, 12. (Recent, Adriatic Sea).

2013 Cytherella alvearium; Cabral \& Loureiro, pl. 1, fig. 2. (Recent continental shelf and slope of Algarve, Portugal).

2015 Cytherella alvearium; Martínez-García et al., pl. 1, fig. 10. (Late Quaternary, Basque shelf).

Distribution. This species is commonly found in this basin in sediments from the interval MIS3-Recent. Live individuals appear in silty sediments deeper than $120 \mathrm{~m}$.

Cytherella lata Brady, 1880

(Fig. 3d) 
1985 Cytherella lata; Guillaume et al., pl. 106, figs 7, 8. (Quaternary, Bathyal E North Atlantic).

2015 Cytherella lata; Martínez-García et al., pl. 1, fig. 11. (Late Quaternary, Basque shelf).

Distribution. In the Basque shelf it is found in the interval MIS3 to Recent. In modern sediments it is very rare in silts deeper than $90 \mathrm{~m}$.

\section{Cytherella robusta Colalongo \& Pasini, 1980}

(Fig. 3e)

1980 Cytherella robusta; Colalongo \& Pasini, p. 78, pl. 6, figs 4-10. (Middle Pliocene-Pleistocene, Calabria, Italy).

2013 Cytherella robusta; Cabral \& Loureiro, pl. 1, fig. 3. (Recent continental shelf and slope of Algarve, Portugal).

2015 Cytherella robusta; Yasuhara \& Okahashi, figs

3, A, B. (Quaternary, deep N Atlantic).

Distribution. In the Basque shelf it is only found in MIS3 of the outer shelf.

Order PODOCOPIDA Sars, 1866

Suborder BAIRDIOCOPINA Gründel, 1967

Superfamily BAIRDIOIDEA Sars, 1866

Family Bairdiidae Sars, 1866

Genus Neonesidea Maddocks, 1969

Type species Neonesidea schulzi (Hartmann, 1964)

Neonesidea aff. corpulenta (G.W. Müller, 1894)

(Fig. 3f)

1976 Neonesidea corpulenta; Bonaduce et al., pl.5, fig. 1. (Recent, Adriatic Sea).

Distribution. Very rare in the Recent Basque shelf.

Neonesidea longevaginata (G.W. Müller, 1894)

(Fig. 3g)

1976 Neonesidea longevaginata; Bonaduce et al., pl. 5, figs 8-11. (Recent, Adriatic Sea).

2013 Neonesidea longevaginata; Cabral \& Loureiro, pl. 9, fig. 12. (Holocene, Portugal).
Distribution. In the Basque shelf it is present during all the Holocene. It also occurs in Recent mid-coarse sands deeper than $120 \mathrm{~m}$.

Neonesidea mediterranea (G.W. Müller, 1894)

(Fig. 3h)

1976 Neonesidea mediterranea; Bonaduce et al., pl.

5, fig. 6. (Recent, Adriatic Sea).

2015 Neonesidea mediterranea; Sciuto et al., pl. 1,

fig. 4. (Recent, Ionian Sea, Sicily).

Distribution. It is present in the Basque shelf during all the Holocene. In moderns samples it appears in sandy and silty sediments 80-130 mwd in the Basque outer shelf.

Suborder CYPRIDOCOPINA Jones, 1901

Superfamily CYPRIDOIDEA Baird, 1845

Family Candonidae Kaufmann, 1900

Genus Paracypris Sars, 1866

Type species Paracypris polita Sars, 1866

Paracypris polita Sars, 1866

(Fig. 3i)

2013 Paracypris polita; Cabral \& Loureiro, pl. 9, fig. 21. (Recent continental shelf and slope of Algarve, Portugal).

2015 Paracypris polita; Martínez-García et al., pl. 1, fig. 20. (Late Quaternary, Basque shelf).

Distribution. In the Basque Basin this species is known from MIS3 to the Recent. Nowadays it can be found alive in silty clay and sands of depth ranges of 98-130 mwd.

Family Macrocyprididae G.W. Müller, 1912

Genus Macrocypris Brady, 1867

Type species Macrocypris minna (Baird, 1850)

Macrocypris minna (Baird, 1850)

(Fig. 3j)

1989 Macrocypris minna; Athersuch et al., p. 67, 68, fig. 23. (Recent British Isles $->50 \mathrm{mwd}$ ).

1990 Macrocypris minna; Maddocks, p. 43, pl. 3, figs 2-4. (Holocene NE Atlantic, continental shelf and slope - 54-1326 mwd). 


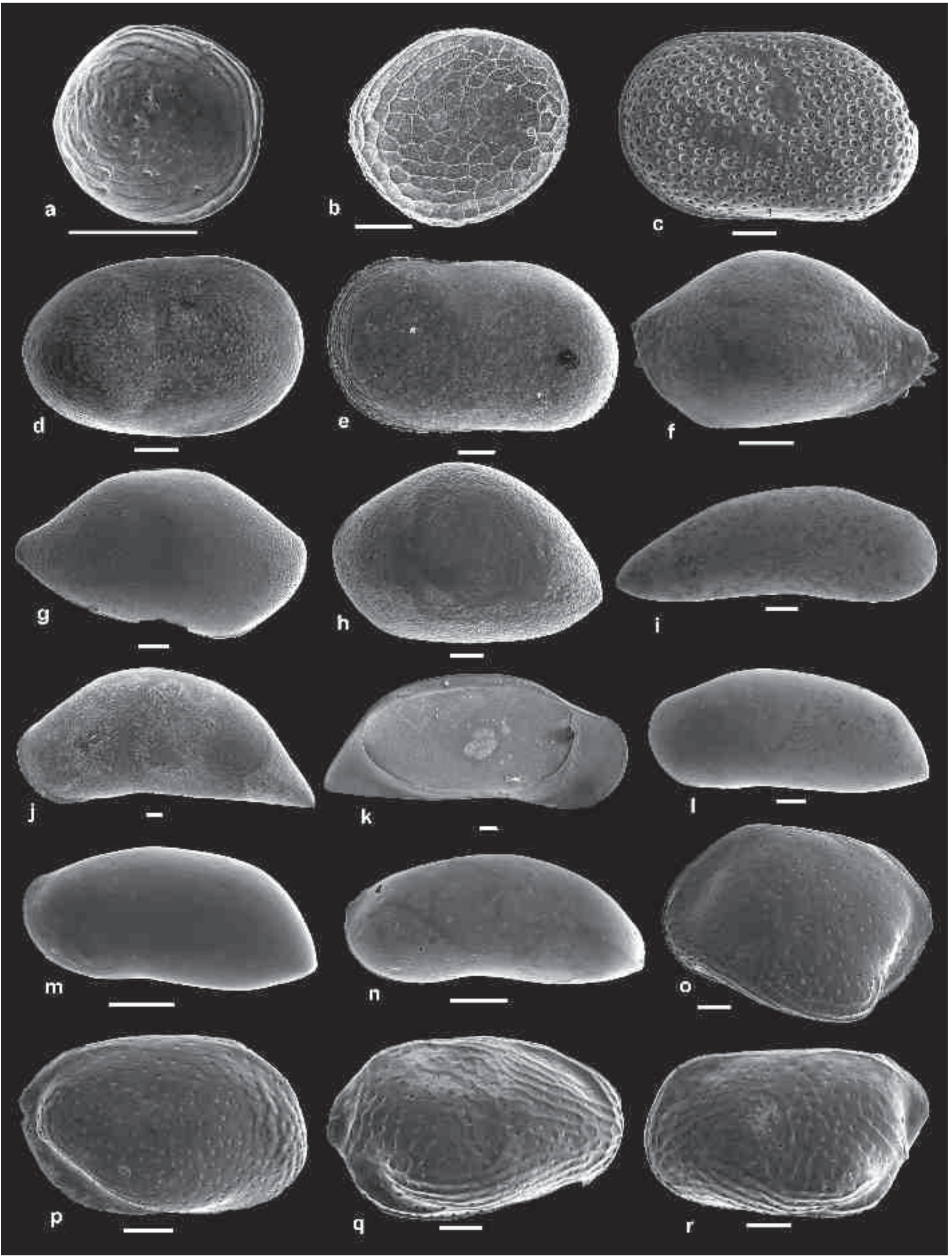


Distribution. Very rare in the Recent of the Basque shelf. Final MIS3 and MIS2 in upper bathyal and mid-late Holocene to Recent in the inner Basque shelf.

\section{Macrocypris tenuicauda Brady, 1880}

(Fig. 3k)

1976 Macrocypris tenuicauda; Puri \& Hulings, pl. 1, figs 11, 12. (Lectotypes of the Challenger expedition).

Distribution. Very rare in the Recent of the Basque shelf. This species has also been found in MIS2 and MIS5c of the bathyal Bay of Biscay.

Superfamily PONTOCYPRIDOIDEA G.W. Müller, 1894

Family Pontocyprididae G.W. Müller, 1894

Genus Argilloecia G.O. Sars, 1866

Type species Argilloecia cylindrica Sars, 1866

Argilloecia bensoni Barra, Aiello \& Bonaduce, 1996

(Fig. 31)

2015 Argilloecia acuminata G.W. Müller; MartínezGarcía et al., pl. 1, fig. 2. (Late Quaternary, Basque shelf).

2015 Argilloecia bensoni; Yasuhara \& Okahashi, figs

4 K-N. (Late Quaternary deep N Atlantic).

Distribution. MIS3 to Recent. It is very scarce in fine-grained sediments of the Recent Basque shelf (110$130 \mathrm{mwd}$ ).

Argilloecia aff. conoidea Sars, 1923

(Fig. 3m)
1928 Argilloecia conoidea; Sars, pl. 25. (Recent, Norway).

1979 Argilloecia conoidea; Yassini, pl. 10, fig. 6. (Recent, Algeria).

1980 Argilloecia sp.; Colalongo \& Pasini, pl. 1, fig.

2. (Pleistocene, S Italy).

1996 Argilloecia conoidea; Whatley et al., pl. 1, figs 3, 4. (Recent, East Greenland).

2013 Argilloecia aff. conoidea; Cabral \& Loureiro, pl. 9, fig. 15. (Recent continental slope of Algarve, Portugal).

2015 Argilloecia conoidea; Martínez-García et al., pl. 1, fig. 3. (Late Quaternary, Basque shelf).

Distribution. In the Recent Basque shelf it occurs very scarcely in fine sediments 80 to $150 \mathrm{mwd}$. Also found in MIS3 of this shelf.

\section{Argilloecia sp. 1}

(Fig. 3n)

Distribution. This species is close to A. aff. conoidea, but it differs by the more elongated outline and different anterior border. In the Basque Basin it is known from MIS3 to Recent. In modern sediments it is found in the depth interval of 70-120 mwd.

Suborder CYTHEROCOPINA Gründel, 1967

Superfamily CYTHEROIDEA Baird, 1850

Family Bythocytheridae Sars, 1866

Genus Bythocythere Sars, 1866

Type species Bythocythere turgida Sars, 1866

Bythocythere bradleyi Athersuch, Horne \& Whittaker, 1983

(Fig. 3o)

Figure 3. Ostracod species from the Basque Basin. Legend for each specimen indicated as (valid for Figs 3-9): species \& author, element (C, carapace; RV, right valve; LV, left valve), microphotograph code, sample, age. Unless indicated all are external views. Scale bars $=100 \mathrm{~mm}$. a) Polycope frequens G.W. Müller, 1894 sensu Bonaduce et al., 1976, juvenile RV, ZTF737, Recent. b) Polycope cf. reticulata G.W. Müller, 1894, LV, 81-32, KS10-183 cm, Early Holocene. c) Cytherella alvearium Bonaduce, Ciampo \& Masoli, 1976, LV, 1537, KS05-231 cm, MIS3. d) Cytherella lata Brady, 1880, RV, 1518, KS05-241 cm, MIS3. e) Cytherella robusta Colalongo \& Pasini, 1980, LV, 1553, KS05-215 cm, MIS3. f) Neonesidea corpulenta (G.W. Müller, 1894), LV, ZTF670, Recent. g) Neonesidea longevaginata (G.W. Müller, 1894), RV, ZTF652, Recent. h) Neonesidea mediterranea (G.W. Müller, 1894), LV, ZTF651, Recent. i) Paracypris polita Sars, 1866, RV, 71-26, KS05 50 cm, modern Holocene. j) Macrocypris minna (Baird, 1850), LV, 82-33, KS05-192 cm, MIS3. k) Macrocypris tenuicauda Brady, 1880, LV interior view, 87-45, PP10-17-1551 cm, MIS5c. I) Argilloecia bensoni Barra, Aiello \& Bonaduce, 1996, LV, 1552, KS05-215 cm. m) Argilloecia aff. conoidea Sars, 1923, LV, ZTF724, Recent. n) Argilloecia sp. 1, LV, ZTF645, Recent. o) Bythocythere bradleyi Athersuch, Horne \& Whittaker, 1983, LV, 1559, KS05-200 cm, MIS3. p) Bythocythere bradyi Sars, 1926, female RV, ZTF659, Recent. q) Bythocythere intermedia Elofson, 1938, female RV, ZTF764, Recent. r) Bythocythere zetlandica Athersuch, Horne \& Whittaker, 1983, LV, ZTF768, Recent. 
1989 Bythocythere bradleyi; Athersuch et al., p. 242, fig. 102; pl. 8, fig. 6. (Recent, British Isles).

Distribution. This species is not present in the Recent of the Basque Basin and it is rare in the Holocene and MIS3 of outer Basque shelf.

\section{Bythocythere bradyi Sars, 1926}

(Fig. 3p)

1989 Bythocythere bradyi; Athersuch et al., p. 244, fig. 103; pl. 8, fig. 7. (Recent, British and Norwegian coastal waters $-<80 \mathrm{mwd}$ ).

2013 Bythocythere bradyi; Cabral \& Loureiro, pl. 1, fig. 7. (Recent outer estuarine, Portugal).

Distribution. Recent Basque and Landes shelves. Holocene and MIS3 of Basque outer shelf.

\section{Bythocythere intermedia Elofson, 1938}

(Fig. 3q)

1989 Bythocythere intermedia; Athersuch et al., p. 246, fig. 104; pl. 8, fig. 8. (Recent, British Isles).

2013 Bythocythere intermedia; Cabral \& Loureiro, pl. 1, fig. 8. (Recent outer estuarine and Holocene, Portugal).

Distribution. This species is rare in the Recent of the Basque shelf (70-130 mwd) and also in the early Holocene of the inner Basque shelf.

Bythocythere zetlandica Athersuch, Horne \& Whittaker, 1983

(Fig. 3r)

1989 Bythocythere zetlandica; Athersuch et al., p. 250, fig. 106; pl. 8, fig. 10. (Recent, British Isles).

Distribution. This species is scarcely found in the Recent of the Basque shelf.

Genus Jonesia Brady, 1866

Type species Jonesia acuminata (Sars, 1866)

Jonesia aff. acuminata (Sars, 1866)

(Fig. 4a)

1981 Jonesis simplex (Norman); Cronin, pl. 3, fig.

10. (Late Pleistocene, Champlain Sea).
1989 Jonesia aff. acuminata; Athersuch et al., p. 252, fig. 107. (Recent, NW Europe and British Isles $-<150 \mathrm{mwd}$ ).

1998 Jonesia acuminata; Freiwald \& Mostafawi, pl. 60, fig. 6. (Recent, Norway fjord).

Distribution. This species is rarely occurring in the mid Holocene of the inner Basque shelf.

Genus Pseudocythere Sars, 1866

Type species Pseudocythere caudata Sars, 1866

\section{Pseudocythere caudata Sars, 1866}

(Fig. 4b)

1979 Pseudocythere caudata; Yassini, pl. 11, figs 18, 19. (Recent, Algeria).

2009 Pseudocythere caudata; Yasuhara et al., pl. 4, figs 7-11. (Quaternary, deep NW Atlantic).

2013 Pseudocythere caudata; Cabral \& Loureiro, pl. 1, fig. 9. (Recent continental shelf of Algarve, Portugal).

2015 Pseudocythere caudata; Yasuhara \& Okahashi, figs 5F, 5G. (Late Quaternary, deep NE Atlantic).

Distribution. This species is very rare in all types of recent sediments in the Basque shelf. Also occurring in Holocene mid to outer shelf (not in recent samples), and MIS3, MIS2 in upper bathyal areas of this basin.

Genus Sclerochilus Sars, 1866

Type species Sclerochilus contortus (Norman, 1862)

Sclerochilus rudjakovi Athersuch \& Horne, 1987

(Fig. 4c)

1989 Sclerochilus rudjakovi; Athersuch et al., p. 270, fig. 115. (Recent, British Isles).

2015 Sclerochilus rudjakovi; Martínez-García et al., pl. 1, fig. 24. (Late Quaternary, Basque shelf).

Distribution. This species is not present in surface samples but it is common in MIS3 to Holocene cores of the Basque Basin.

Family Cuneocytheridae Mandelstam, 1959

Genus Cuneocythere Lienenklaus, 1894

Type species Cuneocythere semipunctata (Brady, 1868) 
Cuneocythere semipunctata (Brady, 1868)

(Fig. 4d)

1976 Cuneocythere semipunctata; Bonaduce et al., p. 60, pl. 28, figs 11, 12. (Recent, Adriatic Sea. In sandy silt sediments less than $194 \mathrm{mwd}$ ).

1985 Cuneocythere semipunctata; Guillaume et al., pl. 103, figs 5, 6. (Recent, outer shelf of Bay of Biscay).

1989 Cuneocythere semipunctata; Athersuch et al., p. 120, fig. 47; pl. 3, fig. 5. (Recent, coasts of Ireland to SW France).

2013 Cuneocythere semipunctata; Cabral \& Loureiro, pl. 1, fig. 12. (Recent continental shelf of Algarve and Holocene, Portugal).

Distribution. This species is present in the Basque Basin from MIS3 to the Recent. It can be found living in fine substrate $(80-150 \mathrm{mwd})$.

Family Cushmanideidae Puri, 1974

Genus Cushmanidea Blake, 1933

Type species Cushmanidea seminuda (Cushman, 1906) Blake, 1933

Cushmanidea turbida (G.W. Müller, 1894) (Fig. 4e)

1965 Cushmanidea turbida; Puri et al., p. 87-199.

Distribution. Found in Holocene to Recent in the Basque shelf, in recent silty sediments (70-151 mwd).

Family Cytheridae Baird, 1850

Genus Cythere O.F. Müller, 1785

Type species Cythere concentrica (Williamson, 1847) Jones, 1849

\section{Cythere lutea O.F. Müller, 1785}

(Fig. 4f)

1941 Cythere lutea; Sylvester-Bradley, p. 27, figs 15-18.

1981 Cythere lutea; Cronin, pl. 4, figs 7, 8. (Late Pleistocene, Champlain Sea).

1985 Cythere lutea; Guillaume et al., pl. 100, figs 3, 4. (Recent, shelf of Bay of Biscay).

1988 Cythere lutea; Cronin, pl. 2, fig. 5. (Pleistocene, postglacial NW Atlantic).
1989 Cythere lutea; Athersuch et al., p. 80, fig. 27; pl. 1, fig. 1. (Recent, coasts of N Atlantic, from Norway to France).

2010 Cythere lutea; Frenzel et al., pl. OS1-2, figs I-L. (Recent Baltic Sea).

Distribution. MIS3 to mid-late Holocene in the inner and outer Basque shelf.

Genus Palmenella Hirschmann, 1916

Type species Palmenella limicola (Norman, 1865) Hirschmann, 1916

Palmenella limicola (Norman, 1865) Hirschmann, 1916 (Fig. 4g)

1981 Palmenella limicola; Cronin, pl. 11, figs 1, 2. (Late Pleistocene, Champlain Sea).

1989 Palmenella limicola; Athersuch et al., p. 82, fig. 28; pl. 1, fig. 2. (Recent, British Isles. Pan-Arctic - Hanai, 1970).

2004 Palmenella limicola; Ozawa, pl. 1, fig. 8. (Recent, outer shelf, 100-200 mwd, cold waters of $\mathrm{N}$ Japan).

Distribution. This species is scarcely found in the interval MIS3-late Holocene in the inner and outer Basque shelf.

Family Cyherideidae Sars, 1925

Genus Heterocyprideis Elofson, 1941

Type species Heterocyprideis sorbyana (Jones, 1857)

Heterocyprideis sorbyana (Jones, 1857)

(Fig. 4h)

1981 Heterocyprideis sorbyana; Cronin, pl. 2, fig. 1. (Late Pleistocene, Champlain Sea).

1985 Heterocyprideis sorbyana; Guillaume et al., pl. 105, figs 1, 2. (Glacial palaeothanathocenoses to Recent, Bay of Biscay).

2006 Heterocyprideis sorbyana; Schornikov \& Zenina, pl. 2, figs 9, 10. (Recent, Arctic Ocean).

2015 Heterocyprideis sorbyana; Schornikov, pl. 2, figs 4, 5, 7, 8 (in Russian).

Distribution. This species is known in Baltic Sea, Beaufort Sea and North Atlantic. In the Basque Basin it 

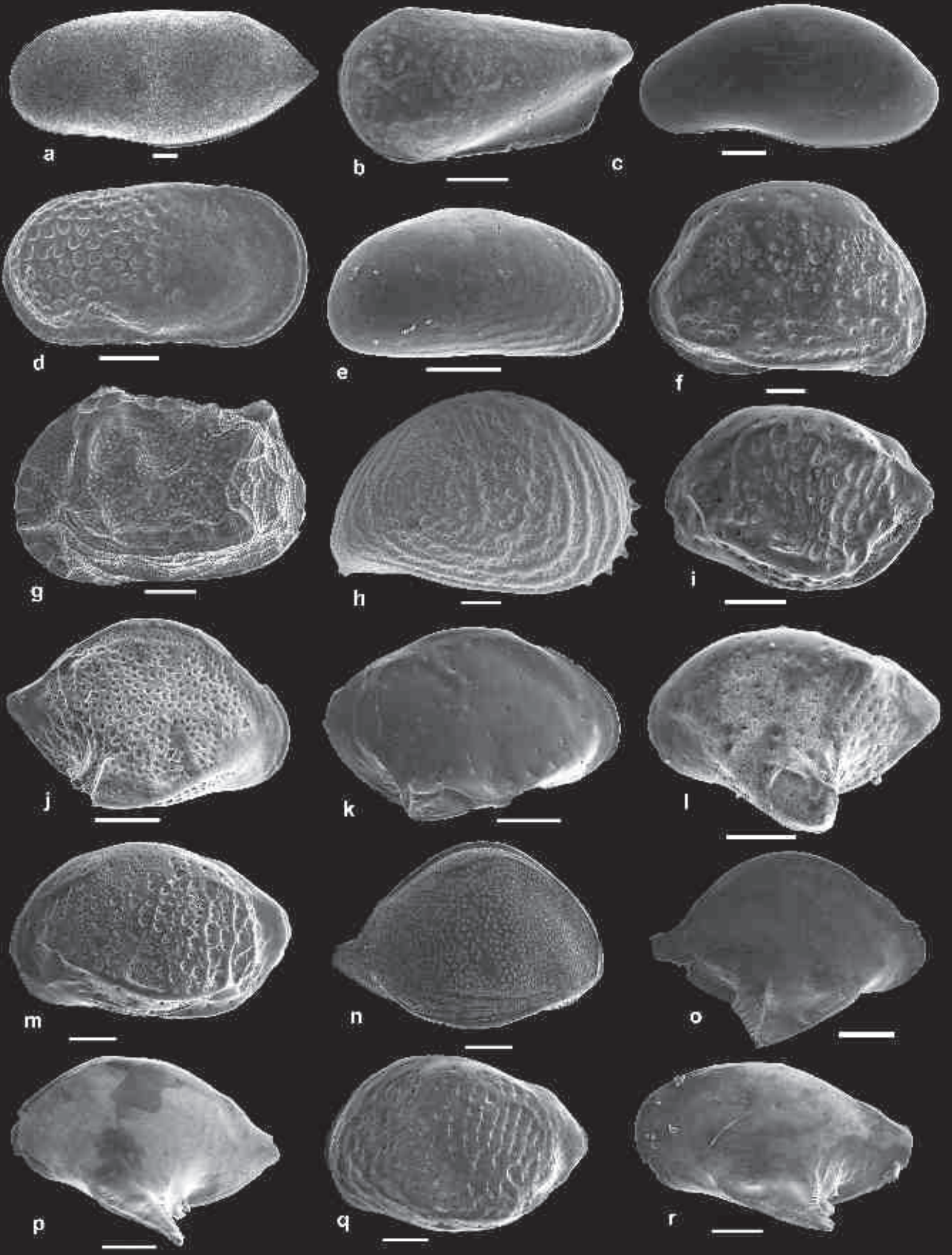
is very rare in MIS3 of the outer shelf and late Holocene to Recent of the inner shelf.

Family Cytheruridae G.W. Müller, 1894

Genus Cytheropteron Sars, 1866

Type species Cythere latissima Norman, 1865

Cytheropteron dorsocostatum Whatley \& Masson, 1979 (Fig. 4i)

1985 Cytheropteron nodosum; Guillaume et al., pl. 101, fig. 3. (Recent, shelf of Bay of Biscay).

1989 Cytheropteron dorsocostatum; Athersuch et al., p. 225, fig. 94; pl. 8, fig. 3. (Recent, N Atlantic, Norway to NW Spain).

1995 Cytheropteron dorsocostatum; Dickson \& Whatley, pl. 1, figs 23, 24. (Recent, East N Atlantic from S Iberia to Norwegian waters; Hoxnian, British Isles).

2013 Cytheropteron dorsocostatum; Cabral \& Loureiro, pl. 1, fig. 17. (Recent continental shelf of Algarve and Holocene, Portugal).

Distribution. It is a common species of MIS3 to Recent in the outer shelf of the Basque Basin.

$$
\begin{gathered}
\text { Cytheropteron hadriaticum Bonaduce, Ciampo \& } \\
\text { Masoli, } 1976
\end{gathered}
$$$$
\text { (Fig. 4j) }
$$

1976 Cytheropteron hadriaticum; Bonaduce et al., p. 93, pl. 54, figs 1-5. (Recent, Adriatic Sea, deep-water sedimens $->70 \mathrm{mwd})$.

1979 Cytheropteron hamatum; Yassini, pl. 10, fig.

12. (Recent, Algeria coastal bay).

1985 Cytheropteron rotundatum; Guillaume et al., pl. 104, fig. 3. (Recent, epibathyal Bay of Biscay).
Distribution. In the Basque Basin it is registered from the mid-late Holocene to the Recent. Doubtful record in the MIS2 of outer Basque shelf.

Cytheropteron cf. ruggierii Pucci, 1956 sensu Bonaduce, Ciampo \& Masoli, 1976

(Fig. 4k)

1976 Cytheropteron ruggierii; Bonaduce et al., pl. 55, fig. 1. (Recent, Adriatic Sea).

1979 Cytheropteron rotundatum; Yassini, pl. 10, fig.

21. (Recent, Algeria coastal bay).

1985 Cytheropteron punctatum; Guillaume et al., pl. 104, figs 9, 10. (Recent, outer shelf of Bay of Biscay).

1989 Cytheropteron inornatum; Athersuch et al., p. 226, fig. 95; pl. 8, fig. 4. (Recent, British Isles).

2003 Cytheropteron inornatum; Guernet et al., p. 88, pl. 3, figs 11-13. (Quaternary, Gulf of Corinthe, Greece).

2013 Cytheropteron cf. ruggierii; Cabral \& Loureiro, pl. 2, fig. 1. (Recent continental shelf and slope of Algarve, Portugal).

2015 Cytheropteron punctatum; Martínez-García et al., pl. 1, fig. 13. (Late Quaternary, Basque shelf).

Distribution. This species is important in the ostracod assemblages during the interval MIS3 to the Recent in the Basque Basin. In modern samples it is less abundant and is occurring in the outer shelf (120-150 mwd).

Cytheropteron crassipinatum Brady \& Norman, 1889 (Fig. 4l)

1976 Cytheropteron monoceros; Bonaduce et al., p. 94, pl. 56, figs 1, 3. (Recent, Adriatic Sea, deeper than $63 \mathrm{mwd}$ in all types of sediments, being more abundant in sandy silt).

Figure 4. Ostracods from the Basque Basin. a) Jonesia aff. acuminata (Sars, 1866), LV, 81-9, KS10-117 cm, modern Holocene. b) Pseudocythere caudata Sars, 1866, LV, ZTF738, Recent. c) Sclerochilus rudjakovi Athersuch \& Horne, 1987, LV, 1547, KS05-231 cm, MIS3. d) Cuneocythere semipunctata (Brady, 1868), RV, 82-32, KS05-195 cm, MIS3. e) Cushmanidea turbida (G.W. Müller, 1894), RV, ZTF644, Recent. f) Cythere lutea O.F. Müller, 1785, female RV, 1543, KS05-231 cm, MIS3. g) Palmenella limicola (Norman, 1865), LV, 1531, KS05-241 cm, MIS3. h) Heterocyprideis sorbyana (Jones, 1857), RV, 9010, KS10-1 cm, Recent. i) Cytheropteron dorsocostatum Whatley \& Masson, 1979, LV, ZTF680, Recent. j) Cytheropteron hadriaticum Bonaduce, Ciampo \& Masoli, 1976, RV, ZTF683, Recent. k) Cytheropteron cf. ruggierii Pucci, 1956, sensu Bonaduce, Ciampo \& Masoli, 1976, RV, 1555, KS05-215 cm, MIS3. I) Cytheropteron crassipinatum Brady \& Norman, 1889, LV, ZTF682, Recent. m) Cytheropteron pararcticum Whatley \& Masson, 1979, LV, 1538, KS05-231 cm, MIS3. n) Cytheropteron testudo Sars, 1869, RV, 1560, KS05-200 cm, MIS3 o) Cytheropteron vespertilio (Reuss, 1850) Brady, 1868, RV, 71-39, KS10-240 cm, Early Holocene. p) Cytheropteron aff. vespertilio (Reuss, 1850) Brady, 1868, LV, ZTF681, Recent. q) Cytheropteron sp. 1, LV, 90-43, KS10-235 cm. r) Cytheropteron sp. 2, LV, FCT659, Recent. 
1979 Cytheropteron monoceros; Yassini, pl. 10, fig. 17. (Recent, Algerian coastal bay).

1980 Cytheropteron monoceros; Colalongo \& Pasini, pl. 16, figs 9, 10. (Pleistocene, S Italy).

2013 Cytheropteron monoceros; Cabral \& Loureiro, 2013, pl. 1, fig. 19. (Recent continental shelf and slope of Algarve, Portugal).

Distribution. This species is present in recent sediments deeper than 130 mwd preferably in silts.

Cytheropteron pararcticum Whatley \& Masson, 1979

(Fig. 4m)

1988 Cytheropteron pararcticum; Cronin, pl. 4, fig.

5. (Pleistocene, postglacial NW Atlantic).

1995 Cytheropteron pararcticum; Dickson \& Whatley, pl. 1, figs 11-13. (Quaternary cold N Atlantic and Subarctic seas. Recent from Arctic to Boreal provinces).

2004 Cytheropteron champlainum; Stepanova et al., pl. 1, fig. 6. (Recent, Laptev Sea).

Remarks. C. champlainum Cronin, 1981, in Stepanova et al. (2004), Recent, Laptev Sea, is a very close form, with posterior caudal process a little more elongated (sexual dimorphism?), probably co-specific.

Distribution. In the Basque Basin only several valves of this species have been found in MIS3, in core samples of the outer shelf.

\section{Cytheropteron testudo Sars, 1869}

(Fig. 4n)

1976 Cytheropteron testudo; Breman, pl. 12, fig. 174. (Recent, Adriatic Sea).

1980 Cytheropteron testudo; Colalongo \& Pasini, pl. 19, fig. 7. (Pleistocene, S Italy).

1985 Cytheropteron testudo; Guillaume et al., pl. 106, figs 9, 10. (Recent, bathyal Bay of Biscay).

2011 Cytheropteron testudo; Faranda \& Gliozzi, figs 12a, 12b. (Calabrian, Mediterraean).

2013 Cytheropteron testudo; Cabral \& Loureiro, pl. 2, fig. 3. (Recent continental slope of Algarve, Portugal).

2015 Cytheropteron testudo; Martínez-García et al., pl. 1, fig. 14. (Late Quaternary, Basque shelf).
Distribution. In the Basque Basin C. testudo is present in deeper outer shelf and epibathyal of the interval MIS3, MIS2 and in the inner shelf during the Holocene.

Cytheropteron vespertilio (Reuss, 1850) Brady, 1868 (Fig. 4o)

1976 Cytheropteron alatum; Breman, pl. 12, fig. 173. (Recent, Adriatic Sea).

1979 Cytheropteron alatum; Yassini, pl. 10, figs 14, 15. (Recent, Algerian coastal bay).

1980 Cytheropteron alatum; Colalongo \& Pasini, pl. 8 , fig. 1. (Pleistocene, S Italy).

1985 Cytheropteron latissimum (Norman, 1865);

Guillaume et al., pl. 103, figs 11, 12. (Recent, outer shelf of Bay of Biscay).

1987 Cytheropteron lineoporosa; Whatley \& Coles, pl. 2, fig. 14. (MIS6, N Atlantic).

1998 Cytheropteron alatum; Freiwald \& Mostafawi, pl. 59, fig. 7. (Recent, Norway fjord).

2013 Cytheropteron volantium; Cabral \& Loureiro, pl. 2, fig. 5. (Recent continental shelf of Algarve, Portugal).

Remarks. C. alatum and C. volantium have been included in this morphologic group. Yasuhara et al. (2014) figured a topotype (RV) of Cytheropteron vespertilio with the same morphology of this group, so all are tentatively included in this specific name.

Distribution. This species is regularly present during MIS3 to Recent in the inner and outer Basque shelf.

Cytheropteron aff. vespertilio (Reuss, 1850) Brady, 1868 (Fig. 4p)

1976 Cytheropteron vespertilio; Bonaduce et al., pl. 52, fig. 7. (Recent, Adriatic Sea).

2013 Cytheropteron vespertilio; Cabral \& Loureiro, pl. 2, fig. 4. (Recent continental shelf of Algarve, Portugal).

Distribution. This species is present with low numbers in the inner and outer Basque shelf during all the Holocene, and a doubtful record in MIS2.

\section{Cytheropteron sp. 1}

(Fig. 4q)

Distribution. This species is rare in the early Holocene of the Basque inner shelf. 


\section{Cytheropteron sp. 2}

(Fig. 4r)

Distribution. This species is rare in the Recent of the Basque shelf.

\section{Cytheropteron sp. 3}

(Fig. 5a)

Remarks. This species is affinis Cytheropteron pyramidale Brady, 1868, but it is left in open name waiting for more material to describe its taxonomy.

Distribution. This species is present in the MIS3 of the outer Basque shelf.

Genus Oculocytheropteron Bate, 1972

Type species Oculocytheropteron praenuntatum Bate, 1972

Oculocytheropteron nodosum (Brady, 1868)

(Fig. 5b)

1978 Cytheropteron nodosum; Robinson, pl. 5, fig. 2. (Ipswichian (MIS5e), marine environments).

1981 Cytheropteron nodosum; Cronin, pl. 7, fig. 8. (Late Pleistocene, Champlain Sea).

1987 Cytheropteron nodosum; Cronin \& ComptonGooding, pl. 5, fig. 7. (Pleistocene, NW Atlantic, site 613 - $2323 \mathrm{mwd}$ ).

1989 Cytheropteron nodosum; Athersuch et al., p. 227, fig. 96; pl. 8, fig. 5. (Recent, NW European waters, Norway to Bay of Biscay).

1995 Cytheropteron nodosum; Dickson \& Whatley, pl. 1, figs 3, 6, 10. (Recent, NE Atlantic).

2015 Cytheropteron nodosum; Martínez-García et al., pl. 1, fig. 12. (Late Quaternary, Basque shelf).

Distribution. This is a common species in the inner and outer shelf of the Basque Basin during the interval MIS3 to Recent.

Genus Cytherura Sars, 1866

Type species Cytherura gibba (O.F. Müller, 1785)

Cytherura gibba? (O.F. Müller, 1785)

(Fig. 5c)

1976 Semicytherura amorpha; Bonaduce et al., p. 70, pl. 41, figs 1-3. (Recent, Adriatic Sea $-<135 \mathrm{mwd}$ ).
1981 Cytherura gibba; Cronin, pl. 5, figs 1-4. (Late Pleistocene, Champlain Sea).

1988 Cytherura gibba; Cronin, pl. 2, fig. 1. (Pleistocene, postglacial NW Atlantic).

1989 Cytherura gibba; Athersuch et al., p. 202, fig. 80; pl. 7, fig. 1. (Recent, brackish waters of NW Europe, Baltic and British Isles).

Distribution. This species is very scarce and have been recorded in Recent Basque shelf, in silty-sandy sediments 50$90 \mathrm{mwd}$. Another record is in MIS5a of deep Bay of Biscay.

Genus Eucytherura G.W. Müller, 1893

Type species Eucytherura complexa (Brady, 1867)

Eucytherura complexa (Brady, 1867)

(Fig. 5d)

1976 Eucytherura complexa; Bonaduce et al., p. 85, pl. 48, figs 8-10. (Recent, Adriatic Sea).

2013 Eucytherura complexa; Cabral \& Loureiro, 2013, pl. 2, fig. 7. (Recent continental shelf of Algarve and Holocene, Portugal).

Distribution. In the Basque Basin this species is regularly present in the Holocene to Recent shelf (110-170 mwd), and only one record from the outer shelf in MIS3.

Eucytherura mistrettai Sissingh, 1972

(Fig. 5e)

1976 Eucytherura mistrettai; Bonaduce et al., p. 85, pl. 49, figs 1-3. (Recent, Adriatic Sea ->70 mwd).

2013 Eucytherura mistrettai; Cabral \& Loureiro, pl. 2, figs 8, 9. (Recent continental shelf of Algarve and Holocene, Portugal).

Distribution. In the Basque Basin it is found in the interval MIS3 to Recent in shelf environments. In modern samples it is present in all types of sediments from 120 to $150 \mathrm{mwd}$.

Genus Hemicytherura Elofson, 1941

Type species Hemicytherura cellulosa (Norman, 1865)

Hemicytherura aff. clathrata (Sars, 1866)

(Fig. 5f)

1988 Hemicytherura clathrata; Cronin, pl. 4, figs 9, 10. (Pleistocene, postglacial NW Atlantic). 

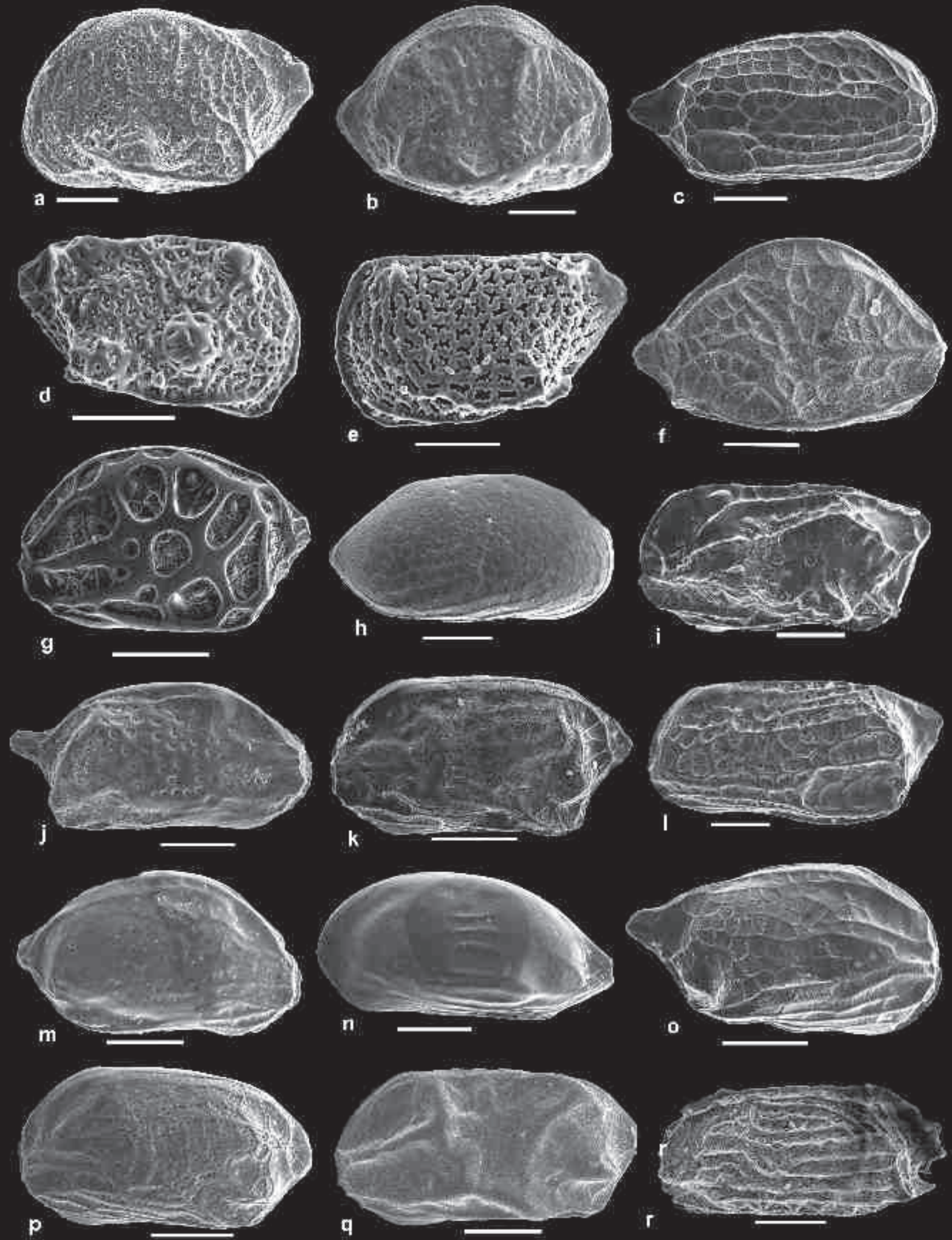
1991 Hemicytherura clathrata; Cronin, pl. 12, fig. 20. (Early Pleistocene, Tjörnes, Iceland).

1998 Hemicytherura clathrata; Freiwald \& Mostafawi, pl. 60, fig. 1. (Recent, Norway fjord).

2009 Hemicytherura clathrata; Whittaker \& Horne, pl. 3, figs 1, 2. (MIS13 to early Holocene).

2010 Hemicytherura clathrata; Frenzel et al., pl. OS1-3, fig. AL. (Post-glacial to Recent, Baltic Sea).

Distribution. This species is found in MIS3 to late Holocene in the outer Basque shelf. The specimens found in MIS3 deep bathyal Bay of Biscay are morphologically the same as the type species. Individuals from the Basque shelf have different lateral ornamentation, with discontinuous medium-lateral ridge.

Hemicytherura hoskini Horne, 1981

(Fig. 5g)

1981 Hemicytherura hoskini; Horne, p. 8, figs 13-18.

1989 Hemicytherura hoskini; Athersuch et al., p. 206, fig. 82; pl. 6, fig. 10. (Recent, British Isles. Marine littoral, phytal).

2013 Hemicytherura hoskini; Cabral \& Loureiro, pl. 2, fig. 14. (Recent continental shelf of Algarve and Holocene, Portugal).

Distribution. This species have been recorded in MIS2 to Recent interval in the Basque shelf. In modern sediments it is found in fine sands and silts 50-112 mwd.

Genus Microcytherura G.W. Müller, 1894

Type species Microcytherura broeckiana (Brady, 1878)

Microcytherura fulva (Brady \& Robertson, 1874) (Fig. 5h)
1976 Microcytherura fulva; Bonaduce et al., p. 89, pl. 57, figs 9-13. (Recent, Adriatic Sea).

2006 Microcytherura fulva: Cabral et al., pl. 1, fig.

2. (Holocene Portugal. Marine shelf).

2013 Microcytherura fulva; Cabral \& Loureiro, pl.

2, fig. 16. (Recent continental shelf and slope of

Algarve and Holocene, Portugal).

Distribution. This is a secondary species in Recent sediments of the Basque shelf.

Genus Semicytherura Wagner, 1957

Type species Semicytherura nigrescens (Baird, 1838)

Semicytherura acuminata (G.W. Müller, 1894)

(Fig. 5i)

1976 Semicytherura acuminata Breman, pl. 10, fig. 149. (Recent, Adriatic Sea).

1976 Semicytherura acuminata; Bonaduce et al., p. 68, pl. 39, figs 1, 3. (Recent, Adriatic Sea. Nearshore $-70-81 \mathrm{mwd})$.

2013 Semicytherura acuminata; Cabral \& Loureiro, pl. 2, fig. 19. (Recent continental shelf of Algarve and Holocene, Portugal).

Distribution. Only found in Recent sediments of the Basque shelf.

\section{Semicytherura angulata (Brady, 1868)}

(Fig. 5j)

1989 Semicytherura angulata; Athersuch et al., p. 211, fig. 85; pl. 7, fig. 4. (Recent, British Isles and NW Europe. Littoral marine to estuarine, phytal species).

2011 Semicytherura angulata; Faranda \& Gliozzi, figs 17a, 17b (Calabrian, Mediterraean).

Figure 5. Ostracods from the Basque Basin. a) Cytheropteron sp. 3, LV, 81-6, KS05-200 cm, MIS3. b) Oculocytheropteron nodosum (Brady, 1868), RV, 1567, KS05-187 cm, MIS3. c) Cytherura gibba? (O.F. Müller, 1785), juvenile? RV, ZTF749, Recent. d) Eucytherura complexa (Brady, 1866), RV, ZTF690, Recent. e) Eucytherura mistrettai Sissingh, 1972, LV, ZTF691, Recent. f) Hemicytherura aff. clathrata (Sars, 1866), RV, 71-3, KS05-242 cm, MIS3. g) Hemicytherura hoskini Horne, 1981, LV, ZTF693, Recent. h) Microcytherura fulva (Brady \& Robertson, 1874), RV, ZTF725, Recent. i) Semicytherura acuminata (G.W. Müller, 1894), LV, ZTF763, Recent. j) Semicytherura angulata (Brady, 1868), RV, FCT691, Recent. k) Semicytherura aff. angulata (Brady, 1868), LV, ZTF751, Recent. I) Semicytherura arcachonensis Yassini, 1969, LV, ZTF752, Recent. m) Semicytherura aff. nigrescens (Baird, 1838), RV, 1550, KS05-215 cm, MIS3. n) Semicytherura aff. simplex (Brady \& Norman, 1889), LV, ZTF755, Recent. o) Semicytherura cf. stilifera Bonaduce et al., 1976, sensu Cabral \& Loureiro, 2013, RV, ZTF761, Recent. p) Semicytherura tela Horne \& Whittaker, 1980, LV, 1554, KS05-215 cm, MIS3. q) Semicytherura undata (Sars, 1866), LV, 71-38, KS10-240 cm, early Holocene. r) Semicytherura sp. 1, LV, ZTF773, Recent. 
2013 Semicytherura angulata; Cabral \& Loureiro, pl. 3, fig. 3. (Holocene, Portugal).

Distribution. This species is very rare in recent Holocene of the Basque shelf. Also present in MIS2 of bathyal Bay of Biscay.

\section{Semicytherura aff. angulata (Brady, 1868)}

(Fig. 5k)

Distribution. This species is scarce in recent sediments of the Basque shelf.

Semicytherura arcachonensis Yassini, 1969

(Fig. 51)

1985 Semicytherura arcachonensis; Guillaume et al., pl. 101, figs 4, 5. (Recent, infralittoral Bay of Biscay).

2013 Semicytherura arcachonensis; Cabral \&

Loureiro, pl. 3, fig. 5. (Holocene, Portugal).

Distribution. This species is regularly present in the interval MIS3 to Recent in the Basque shelf. In modern sandy and silty sediments it is found in depths shallower than $80 \mathrm{mwd}$.

\section{Semicytherura aff. nigrescens (Baird, 1838)}

(Fig. $5 \mathrm{~m}$ )

aff. 1989 Semicytherura nigrescens; Athersuch et al., p. 208, fig. 83; pl. 7, fig. 2. (Recent, British Isles and NW Europe, Bay of Biscay to SW Greenland. Littoral marine to estuarine, phytal species).

Distribution. $S$. aff. nigrescens have been only found in MIS3 of the outer Basque shelf.

Semicytherura aff. simplex (Brady \& Norman, 1889) Yassini, 1969

(Fig. 5n)

aff. 1989 Semicytherura simplex; Athersuch et al., p. 216, fig. 88; pl. 7, fig. 7. (Recent, British Isles and Mediterranean. Phytal, littoral).

aff. 2013 Semicytherura simplex; Cabral \& Loureiro, pl. 3, fig. 13. (Holocene, Portugal).

Distribution. This species is rare in the modern Holocene of the Basque shelf.

\section{Semicytherura cf. stilifera Bonaduce, Ciampo \&} Masoli, 1976

(Fig. 5o) cf. 1976 Semicytherura stilifera; Bonaduce et al., p. 80, pl. 43, figs 1-4. (Recent, Adriatic Sea. Deep shelf (71-224 mwd), more abundant in medium sands).

2013 Semicytherura cf. stilifera; Cabral \& Loureiro, pl. 3, fig. 14. (Recent continental shelf of Algarve and Holocene, Portugal).

Distribution. This species is occurring in the interval MIS3 to Recent in the Basque shelf, mostly in sandy and silty-clay sediments.

\section{Semicytherura tela Horne \& Whittaker, 1980}

(Fig. 5p)

1989 Semicytherura tela; Athersuch et al., p. 218, fig. 90; pl. 7, fig. 9. (Recent, British Isles and S Bay of Biscay. Littoral marine to brackish water species).

2013 Semicytherura tela; Cabral \& Loureiro, pl. 3, fig. 17. (Recent littoral-outer estuarine and rockpool, living- and Holocene, Portugal).

Distribution. This species is rare in MIS3 and midlate Holocene of the outer Basque shelf.

Semicytherura undata (Sars, 1866)

(Fig. 5q)

1985 Semicytherura undata; Guillaume et al., pl. 101, figs 1, 2. (Recent, infralittoral Bay of Biscay).

1989 Semicytherura undata; Athersuch et al., p. 220, fig. 91; pl. 7, fig. 10. (Recent, British Isles, Scandinavia and Arctic. Shallow sublittoral).

1991 Hemicytherura undata; Cronin, pl. 12, figs 16, 17, 19. (Early Pleistocene, Tjörnes, Iceland).

2013 Semicytherura undata; Cabral \& Loureiro, pl. 3, fig. 18. (Holocene, Portugal).

Distribution. This species is found in MIS5, MIS3 in bathyal Bay of Biscay and in Holocene to Recent of the outer Basque shelf.

\section{Semicytherura sp. 1}

(Fig. 5r)

Distribution. This species is rarely found in HoloceneRecent and MIS3 sediments of the outer Basque shelf.

\section{Semicytherura sp. 2}

(Fig. 6a) 
Distribution. This species is rarely found in HoloceneRecent sediments of the outer Basque shelf.

Family Eucytheridae Puri, 1954

Genus Eucythere Brady, 1868

Type species Cythere declivis Norman, 1865

Eucythere anglica Brady, 1868

(Fig. 6b)

1976 Eucythere curta Ruggieri; Breman, pl. 6, fig. 75. (Recent, Adriatic Sea).

1976 Eucythere curta; Bonaduce et al., pl. 37, fig. 10. (Recent, Adriatic Sea).

1979 Eucythere declivis (Norman); Yassini, pl. 8, fig.17. (Recent, Algeria coastal bay.

1985a Eucythere anglica; Horne \& Whittaker, figs 7-10.

1989 Eucythere anglica; Athersuch et al., p. 89, fig. 30; pl. 2, fig. 8. (Recent, British Isles).

2013 Eucythere anglica; Cabral \& Loureiro, pl. 3, fig. 21. (Recent continental shelf and slope of Algarve, Portugal).

2015 Eucythere anglica; Martínez-García et al., pl. 1, fig. 15. (Late Quaternary, Basque shelf).

Distribution. This species is very scarce in modern sediments, but appears regularly in the interval MIS3 to Recent of the inner and outer Basque shelf.

Eucythere curta Ruggieri, 1975

(Fig. 6c)

1976 Eucythere curta; Bonaduce et al., pl. 37, fig. 9. (Recent, Adriatic Sea).

Distribution. This species is present in recent sandy sediments of the outer Basque shelf. A few valves have been found in MIS3 and late Holocene of this shelf.

Family Hemicytheridae Puri, 1953a

Genus Aurila Pokorny, 1955

Type species Aurila convexa (Baird, 1850)

Aurila convexa (Baird, 1850)

(Fig. 6d)

1976 Aurila convexa; Breman, pl. 9, fig. 120. (Recent, Adriatic Sea).
1979 Aurila convexa; Yassini, pl. 5, figs 7, 8. (Recent, Algerian coastal bay).

1985 Aurila convexa; Guillaume et al., pl. 99, figs 3,

4. (Recent, phytal coastal Bay of Biscay).

1989 Aurila convexa; Athersuch et al., p. 157,

fig. 62; pl. 5, fig. 1. (Recent, British Isles to

Mediterranean. Phytal to shallow sublittoral).

2003 Aurila convexa; Guernet et al., p. 88, pl. 2, fig.

1. (Quaternary, Gulf of Corinthe, Greece).

2013 Aurila convexa; Cabral \& Loureiro, pl. 4, fig.

4. (Recent, continental shelf and slope of Algarve and Holocene, Portugal).

Distribution. This is a common species in the inner Basque shelf during the interval early Holocene to Recent.

Aurila woutersi Horne, 1986

(Fig. 6e)

1986 Aurila woutersi; Horne, 13, p. 33-38.

1989 Aurila woutersi; Athersuch et al., p. 160, fig. 64; pl. 5, fig. 2. (Recent, British Isles. Phytal to shallow sublittoral).

2013 Aurila woutersi; Cabral \& Loureiro, pl. 4, fig.

5. (Holocene, Portugal).

2015 Aurila woutersi; Martínez-García et al., pl. 1, fig. 4. (Late Quaternary, Basque shelf).

Distribution. This species is present in the inner Basque shelf during the interval early Holocene to Recent.

Genus Caudites Coryell \& Fields, 1937

Type species Caudites medialis Coryell \& Fields, 1937

Caudites calceolatus (Costa, 1853)

(Fig. 6f)

1976 Caudites calceolatus; Bonaduce et al., pl. 26, figs 10, 12. (Recent, Adriatic Sea).

1994 Caudites calceolatus; Ruíz Muñoz, pl. 6, figs 1,

2. (Recent, shelf, Huelva, S Spain).

2013 Caudites calceolatus; Cabral \& Loureiro, pl.

4, fig. 6. (Recent, continental shelf of Algarve and Holocene, Portugal).

Distribution. This species is found alive in recent sediments of the Basque shelf, with depth ranges of 50 to $120 \mathrm{mwd}$

Genus Elofsonella Pokorny, 1955 

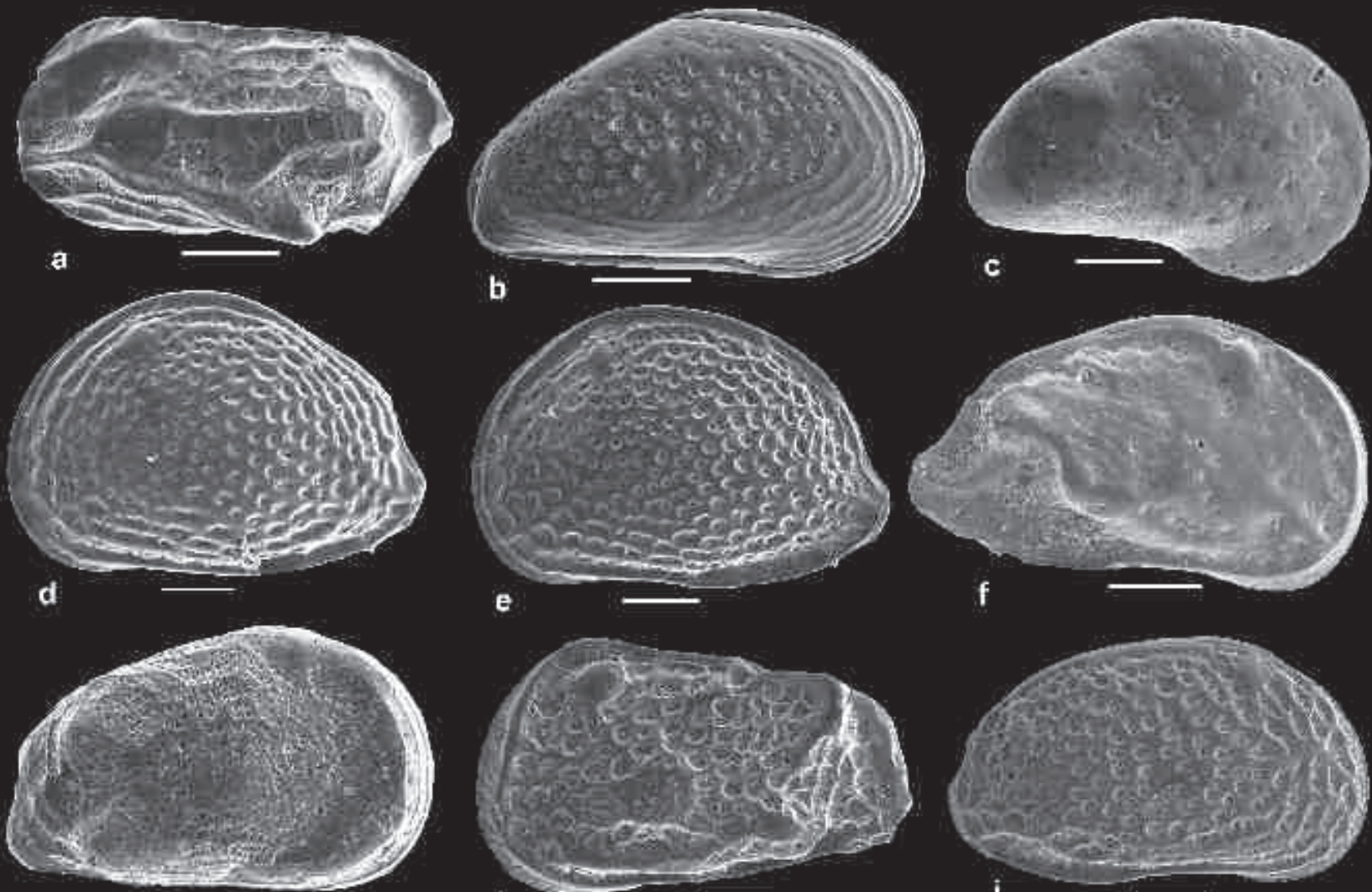

e
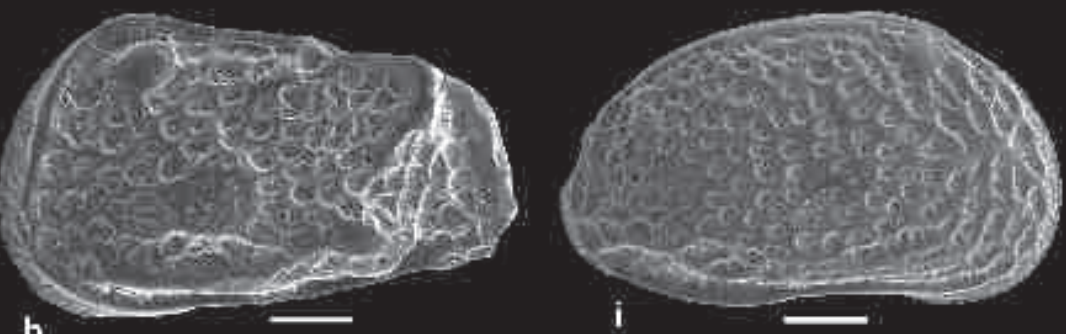

g

h
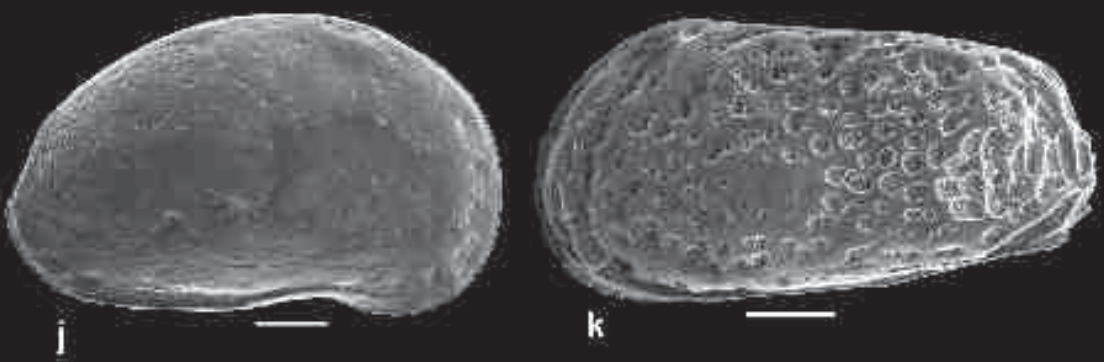

k
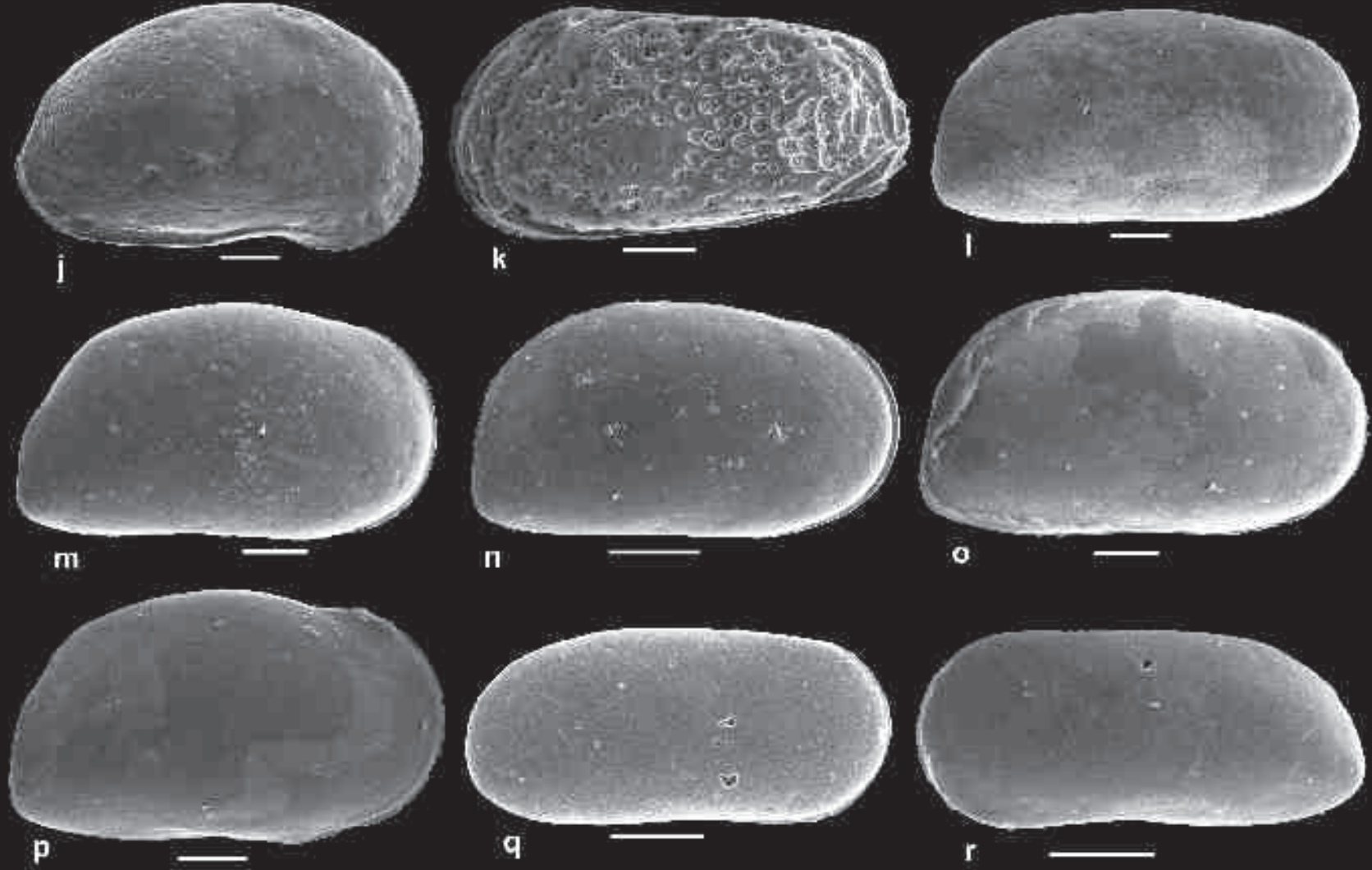
Type species Elofsonella concinna (Jones, 1857)

Pokorny, 1955

Elofsonella concinna (Jones, 1857) Pokorny, 1955 (Fig. 6g)

1985 Elofsonella concinna; Guillaume et al., pl. 105, figs 3, 4. (Recent, glacial palaeothanatocoenoses of Bay of Biscay).

1988 Elofsonella concinna; Cronin, pl. 2, figs 11, 12. (Pleistocene, postglacial NW Atlantic).

1989 Elofsonella concinna; Athersuch et al., p. 162, fig. 65; pl. 5, fig. 3. (Recent, British Isles, Scandinavia, Iceland, NE N America. Mostly deepwater species: 2-250 mwd total depth range, in silt and sandy silt sediments).

2006 Elofsonella sp. A; Schornikov \& Zenina, pl. 3, figs 10, 11. (Recent, Arctic Ocean).

Distribution. This species is rarely found in MIS3, MIS2 and in the Recent of the outer Basque shelf.

Genus Finmarchinella Swain, 1963

Type species Finmarchinella finmarchica (Sars, 1866)

Subgenus Finmarchinella (Barentsovia) Neale, 1974

Finmarchinella (Barentsovia) angulata (Sars, 1866) (Fig. 6h)

1987 Finmarchinella angulata; Cronin \& Ikeya, pl. 1, fig. 9. (Plio-Pleistocene, Japan).

1991 Finmarchinella angulata; Cronin, pl. 14, figs 10, 11. (Early Pleistocene, Tjörnes, Iceland).

2013 Finmarchinella angulata; Cabral \& Loureiro, pl. 4, fig. 7. (Holocene, Portugal).
Distribution. This species has been recorded in the interval MIS3 to Recent of the Basque inner and outer shelf.

Genus Hemicythere Sars, 1925

Type species Hemicythere villosa (Sars, 1866)

Hemicythere villosa (Sars, 1866)

(Fig. 6i)

1989 Hemicythere villosa; Athersuch et al., p. 152, fig. 60; pl. 4, fig. 8. (Recent, British Isles and NW Europe. Littoral to shallow marine shelf in algae and sediments).

2013 Hemicythere villosa; Cabral \& Loureiro, pl. 4, fig. 9. (Holocene, Portugal).

Distribution. This species is recorded in the interval MIS3 to mid-late Holocene in the Basque inner and outer shelf.

Genus Heterocythereis Elofson, 1941

Type species Heterocythereis albomaculata (Baird, 1838)

Heterocythereis albomaculata (Baird, 1838) (Fig. 6j)

1957 Heterocythereis albomaculata; Wagner, p. 57, pl. 24, figs 1-7. (Holocene, vegetated shelf, 2-30 mwd, N Europe and Mediterranean).

1979 Heterocythereis albomaculata; Yassini, pl. 5, fig. 10. (Recent, Algerian coastal bay).

1979 Heterocythereis albomaculata; Athersuch \& Whittaker, p. 117-124.

1985 Heterocythereis albomaculata; Guillaume et al., pl. 110, figs 6a, 6b. (Recent, intertidal Bay of Biscay).

Figure 6. Ostracods from the Basque Basin. a) Semicytherura sp. 2, LV, FCT689, Recent. b) Eucythere anglica Brady, 1868, C right view, 71-32, KS05-22 cm, late Holocene. c) Eucythere curta Ruggieri, 1975, RV, ZTF688, Recent. d) Aurila convexa (Baird, 1850), LV, ZTF648, Recent. e) Aurila woutersi Horne, 1986, LV, ZTF647, Recent. f) Caudites calceolatus (Costa, 1853), RV, FCT640, Recent. g) Elofsonella concinna (Jones, 1857), RV, 82-7, KS05-241 cm, MIS3. h) Finmarchinella (Barentsovia) angulata (Sars, 1866), LV, 1533, KS05-241 cm, MIS3. i) Hemicythere villosa (Sars, 1866), female RV, 7140, KS10-240 cm, Early Holocene. j) Heterocythereis albomaculata (Baird, 1838), RV, ZTF699, Recent. k) Urocythereis britannica Athersuch, 1977, LV, 90-40, KS10-217 cm, Early Holocene. l) “Krithe” gr. bartonensis (Jones, 1857), RV, 1527, KS05-241 cm, MIS3. m). Krithe dolichodeira Bold, 1946, female RV, 1561, KS05-200 cm, MIS3. n) Krithe minima Coles, Whatley \& Moguilevsky, 1994, female C right view, 90-53, KS05-242 cm, MIS3. o) Krithe morkhoveni Bold, 1960, RV, 90-51, KS05-242 cm, MIS3. p) Krithe gr. pernoides (Bornemann, 1855), RV, KS10-49 cm, Middle Holocene. q) Pseudopsammocythere similis (G.W. Müller, 1894), RV, 81-39, KS05-145 cm, Middle Holocene. r) Parakrithe sp. 1, LV, 90-31, KS10-150 cm, Middle Holocene. 
1989 Heterocythereis albomaculata; Athersuch et al., p. 165, fig. 66; pl. 5, fig. 4. (Recent, British Isles).

2013 Heterocythereis albomaculata; Cabral \& Loureiro, pl. 4, fig. 10. (Recent, littoral-outer estuarine and rockpool, living- continental shelf of Algarve and Holocene, Portugal).

2014 Heterocythereis albomaculata; Meireles et al., pl. 5, figs A-G. (Recent, intertidal to $69 \mathrm{mwd}$, Azores).

2015 Heterocythereis albomaculata; Martínez-García et al., pl. 1, fig. 16. (Late Quaternary, Basque shelf).

Distribution. This species is present in the Basque shelf during the interval MIS3 to Recent. Nowadays it is living in the inner and outer shelf (50-93 mwd).

Genus Urocythereis Ruggieri, 1950

Type species Urocythereis favosa (Roemer, 1838)

Urocythereis britannica Athersuch, 1977

(Fig. 6k)

1987 Urocythereis favosa; Aranki, pl. 19, fig. 8. (Recent, S Spain, shelf - 10-12 mwd).

1989 Urocythereis britannica; Athersuch et al., p. 170, fig. 68; pl. 5, fig. 6. (Recent, British Isles and Bay of Biscay to Norway).

2010 Urocythereis oblonga (Brady, 1866); Nachite et al., pl. 2, fig. 2. (Recent, Tahadart estuary, Maroc).

2013 Urocythereis britannica; Cabral \& Loureiro, pl. 4, fig. 11. (Recent, continental shelf and slope of Algarve and Holocene, Portugal).

2015 Urocythereis britannica; Martínez-García et al., pl. 1, fig. 26. (Late Quaternary, Basque shelf).

Distribution. This species is found from MIS3 to the Recent in the Basque shelf.

Family Krithidae Mandelstam, 1958

Genus Krithe Brady, Crosskey \& Robertson, 1874

Type species Ilyobates praetexta Sars, 1866

"Krithe” gr. bartonensis (Jones, 1857) (Fig. 61)

1977 Krithe bartonensis; Peypouquet, figs 1, 12. (Quaternary, deep Bay of Biscay).

2015 Krithe dolichodeira; Martínez-García et al., pl. 1, fig. 17. (Late Quaternary, Basque shelf).
Remarks. This species has recently been included in the genus Thracella, as Thracella bartonensis (Jones, 1857) Faure \& Guernet, 1988 (Brandão et al., 2017), but we left it provisionally in "Krithe" waiting for a revision of this genus by the authors.

Distribution. This species is found living today in low numbers in modern samples of the Basque shelf, but it was abundant in the interval MIS3-MIS2 in the outer shelf and during the Holocene in the inner shelf.

\section{Krithe dolichodeira Bold, 1946}

(Fig. 6m)

1994 Krithe dolichodeira; Coles et al., p. 81, figs 3 L-Q; pl. 2, figs 13-18. (Quaternary, deep N Atlantic. Complete synonymies therein).

1996 Krithe dolichodeira; Coles et al., pl. 4, figs 11-13. (Quaternary, Porcupine Basin, Ireland. Upper bathyal).

Distribution. This species is abundant in MIS5 to MIS2 of deep bathyal Bay of Biscay. In the outer Basque shelf only few juveniles have been found in MIS3.

Krithe minima Coles, Whatley \& Moguilevsky, 1994

(Fig. 6n)

1994 Krithe minima; Coles et al., p. 88, figs 3, EE-JJ; pl. 2, figs 16-18. (Quaternary, deep N Atlantic).

1996 Krithe minima; Coles et al., pl. 4, figs 16-17. (Quaternary, Porcupine Basin, Ireland. Upper bathyal).

Distribution. This is a common species in deep Bay of Biscay during MIS2, MIS3, MIS5. It is very scarce in Recent samples of the outer Basque shelf.

Krithe morkhoveni Bold, 1960

(Fig. 6o)

1994 Krithe morkhoveni; Coles et al., p. 94, pl. 3, figs 11-18. (Quaternary. Deep N Atlantic. Complete synonymies therein).

1996 Krithe morkhoveni; Coles et al., pl. 4, figs 1819. (Quaternary, Porcupine Basin, Ireland. Upper bathyal).

2015 Krithe morkhoveni; Martínez-García et al., pl. 1, fig. 18. (Late Quaternary, Basque shelf).

Distribution. This species is abundant in MIS5 to MIS2 of deep bathyal Bay of Biscay. In the outer Basque shelf only few individuals have been found in MIS3. 
Krithe gr. pernoides (Bornemann, 1855)

(Fig. 6p)

1994 Krithe pernoides; Coles et al., p. 88, figs 5, EE-JJ; pl. 2, figs 16-18. (Quaternary, deep N Atlantic).

Distribution. This species is only found in MIS3 and early Holocene of the outer Basque shelf.

Genus Pseudopsammocythere Carbonnel, 1966

Type species Paradoxostoma simile G.W. Müller, 1894

Pseudopsammocythere similis (G.W. Müller, 1894)

(Fig. 6q)

2013 Pseudopsammocythere similis; Cabral \&

Loureiro, pl. 4, fig. 15. (Recent, continental shelf and slope of Algarve, Portugal).

Distribution. This species is very rare in modern samples, but it is common in the Holocene to the Recent in the outer Basque shelf.

Genus Parakrithe Bold, 1958

Type species Parakrithe vermunti (Bold, 1946) Bold, 1958

\section{Parakrithe sp. 1}

(Fig. 6r)

1977 Parakrithe sp. A2, ecotype 3.2; Peypouquet, figs 11, 32. (Bay of Biscay, 130-625 mwd).

Distribution. To date, this species has been only found in early Holocene and modern samples of the inner Basque shelf.

Parakrithe dimorpha Bonaduce, Ciampo \& Masoli, 1976

(Fig. 7a)

2013 Parakrithe dimorpha; Cabral \& Loureiro, pl. 4, fig. 14. (Recent, continental slope of Algarve, Portugal).

Distribution. This species is quite common in the deep bathyal MIS5, MIS4 Bay of Biscay but very rare in the outer Basque shelf during the Holocene.
Family Leptocytheridae Hanai, 1957

Genus Callistocythere Ruggieri, 1953

Type species Callistocythere littoralis (G.W. Müller, 1894)

Callistocythere curryi Horne, Lord, Robinson \& Whittaker, 1990

(Fig. 7b)

1994 Callistocythere rastrifera; Ruíz Muñoz, pl. 2, figs 9, 10. (Recent, shelf, Huelva, S Spain).

2009 Callistocythere curryi; Whittaker \& Horne, pl. 2, figs 7, 8. (MIS13 to MIS5e. British Isles).

2013 Callistocythere curryi; Cabral \& Loureiro, pl. 4, fig. 17. (Recent, continental shelf and slope of Algarve and Holocene, Portugal).

Distribution. Only found in recent sediments of the Basque shelf.

Callistocythere littoralis (G.W. Müller, 1894)

(Fig. 7c)

1972 Callistocythere littoralis; Uffenorde, pl. 7, fig.

2. (Recent, N Adriatic Sea).

1976 Callistocythere littoralis; Bonaduce et al., pl. 11, figs 1-5. (Recent, Adriatic Sea).

1976 Callistocythere littoralis; Breman, pl. 8, fig. 96. (Recent, Adriatic Sea).

1980 Callistocythere littoralis; Athersuch \& Whittaker, p. 61-66.

1989 Callistocythere littoralis; Athersuch et al., p. 108, fig. 41; pl. 2, fig. 4. (Phytal littoral to sublittoral species. Recent, NE Atlantic coasts to France and Mediterranean).

2013 Callistocythere littoralis; Cabral \& Loureiro, pl. 4, fig. 21. (Recent, continental shelf of Algarve and Holocene, Portugal).

Distribution. This species is found in mid-late Holocene sediments of the Basque shelf.

Genus Cluthia Neale, 1973

Type species Cluthia cluthae (Brady, Crosskey \& Robertson, 1874)

Cluthia keiji Neale, 1975a

(Fig. 7d) 


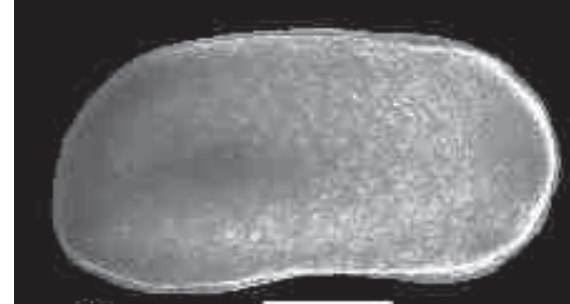

a

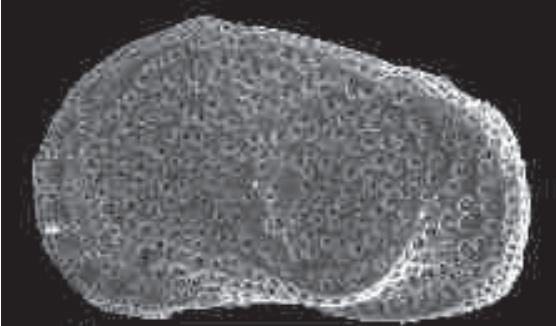

d.

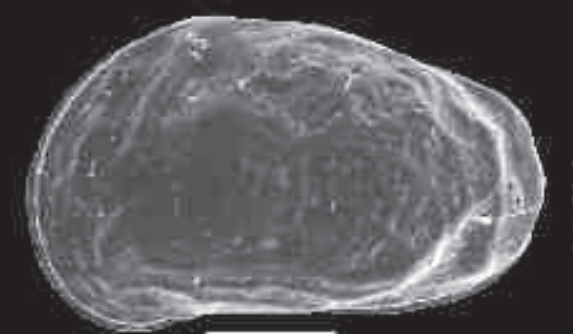

G.
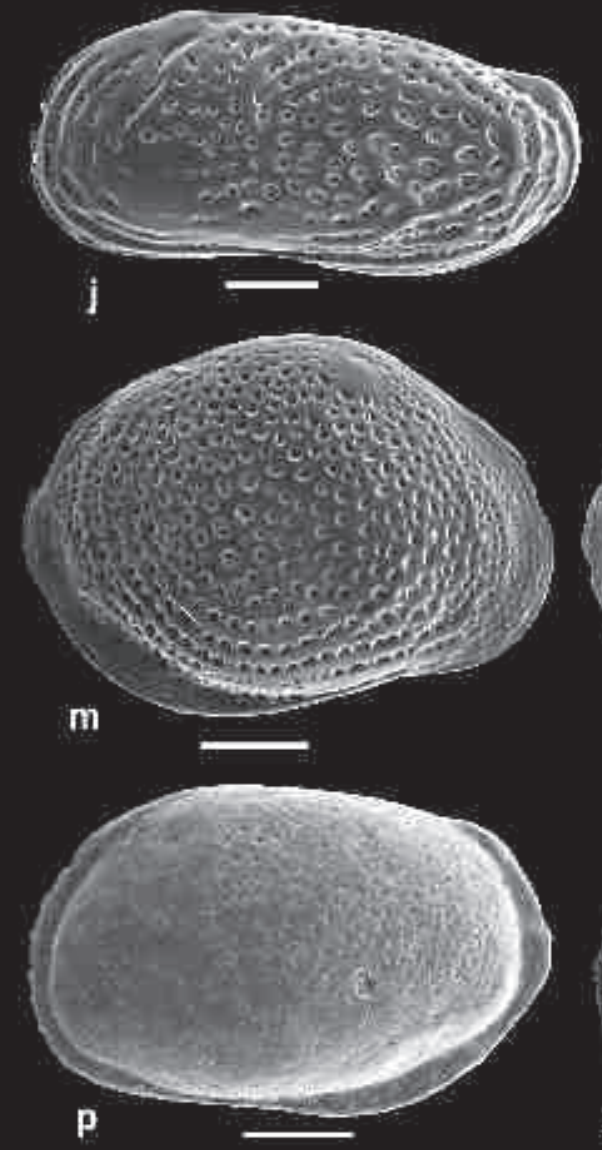
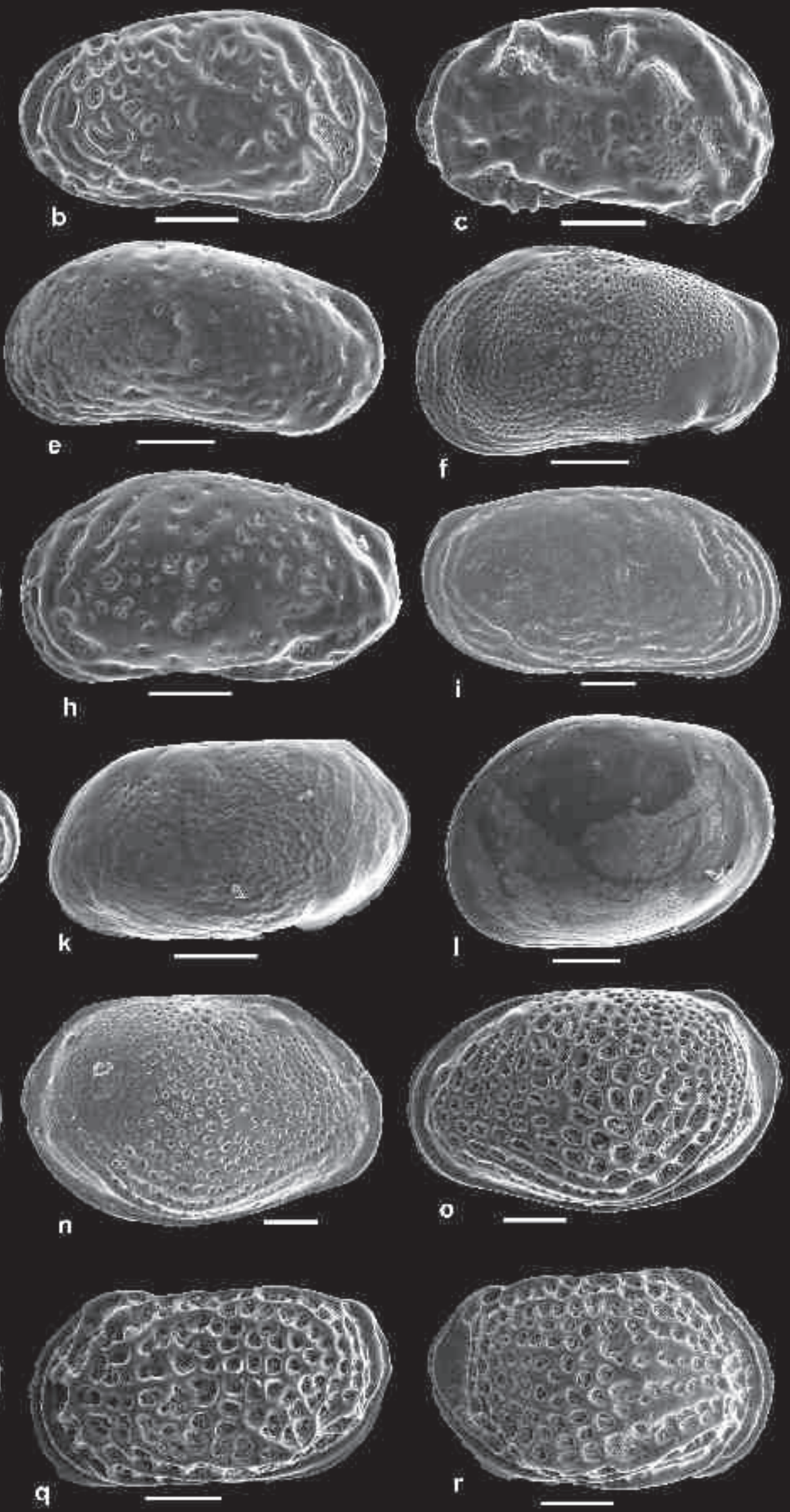
1975a Cluthia keiji; Neale, 2-23, p. 141-148.

(Recent, Mediterranean off E Spain - 81 mwd).

1976 Cluthia keiji; Bonaduce et al., p. 42, pl. 14, figs

1-5. (Recent, Adriatic Sea, shelf ( $>85 \mathrm{mwd}$ ) on silty/ sandy sediments).

1976 Cluthia keyi; Breman, pl. 7, fig. 101. (Recent, Adriatic Sea).

1996 Cluthia keiji; Coles et al., pl. 5, figs 1, 2. (Quaternary, Porcupine Basin, Ireland. Upper bathyal).

2013 Cluthia keiji; Cabral \& Loureiro, pl. 5, fig. 3. (Recent, continental shelf of Algarve, Portugal. Continental shelf).

Distribution. This species is scarcely present in the Late Holocene of the Basque shelf in fine sandy, silty clay and rocky substrates $(>80 \mathrm{mwd})$. A punctual record has been done in MIS2 of the outer Basque shelf.

Genus Leptocythere Sars, 1925

Type species Leptocythere pellucida (Baird, 1850) Sars, 1925

Leptocythere baltica Klie, 1929

(Fig. 7e)

1985 Leptocythere porcellanea; Guillaume et al., pl. 107, figs 11, 12. (Recent, intertidal shelf of Bay of Biscay).

1989 Leptocythere baltica; Athersuch et al., p. 98, fig. 34; pl. 1, fig. 5. (Recent, NW European coasts, from the Bay of Biscay to the Baltic Sea. Shallow water $(<10 \mathrm{mwd})$ in sands with algae).

2013 Leptocythere baltica; Cabral \& Loureiro, pl. 5, fig. 4. (Recent estuarine (living), Portugal).

Distribution. This species is very scarce in samples of MIS3 and Holocene of the Basque shelf.
Leptocythere castanea (Sars, 1866)

(Fig. 7f)

1985 Leptocythere castanea; Guillaume et al., pl. 107, figs 4, 5. (Recent, intertidal shelf of Bay of Biscay).

1989 Leptocythere castanea; Athersuch et al., p. 100, fig. 35; pl. 1, fig. 6. (Recent, NW European coasts, from the Bay of Biscay to the Baltic Sea and S Greenland. Brackish water of estuaries in mud with algae).

2013 Leptocythere castanea; Cabral \& Loureiro, pl. 5, fig. 5. (Holocene, Portugal).

Distribution. Due to the brackish-water character of this species, it is only found in few MIS3 and Holocene samples, very probably transported from the coast to the Basque shelf.

Leptocythere aff. lacertosa (Hirschmann, 1912) (Fig. 7g)

1985 Leptocythere lacertosa; Guillaume et al., pl. 107, figs 16, 17. (Recent, intertidal shelf of Bay of Biscay).

1989 Leptocythere lacertosa; Athersuch et al., p. 102, fig. 36; pl. 1, figs 7, 8. (Recent, NW European coasts, from the Bay of Biscay to the Baltic Sea and Iceland. Brackish water of estuaries in mud or fine sand).

2013 Leptocythere lacertosa; Cabral \& Loureiro, pl. 5, figs 9, 10. (Recent estuarine (living) and Holocene, Portugal).

Distribution. This species is only found in few Holocene and MIS3 samples, very probably transported from the coast to the Basque shelf.

Leptocythere macallana (Brady \& Robertson, 1869) (Fig. 7h)

Figure 7. Ostracods from the Basque Basin. a) Parakrithe dimorpha Bonaduce, Ciampo \& Masoli, 1975, C right view, 81-40, KS05-145 cm, Middle Holocene. b) Callistocythere curryi Horne et al., 1990, female RV, FCT693, Recent. c) Callistocythere littoralis (G.W. Müller, 1894), RV, ZTF662, Recent. d) Cluthia keiji Neale, 1975a, female LV, ZTF774, Recent. e) Leptocythere baltica Klie, 1929, female LV, ZTF711, Recent. f) Leptocythere castanea (Sars, 1866), juvenile LV, ZTF707, Recent. g) Leptocythere aff. lacertosa (Hirschmann, 1912), juvenile LV, FCT643, Recent. h) Leptocythere macallana (Brady \& Robertson, 1869), female LV, ZTF709, Recent. i) Leptocythere pellucida (Baird, 1850), female RV, smooth form, 82-42, KS05-175 cm, MIS3. j) Leptocythere pellucida (Baird, 1850), male RV, ornate form, ZTF706, Recent. k) Elofsonia pusilla (Brady \& Robertson, 1870), LV, ZTF712, Recent. I) Loxoconcha elliptica Brady, 1868, female LV, ZTF715, Recent. m) Loxoconcha rhomboidea (Fischer, 1855), female RV, ZTF722, Recent. n) Loxoconcha sp. 1 aff. Loxoconcha linleyi Horne, 1982, RV, 82-35, KS05$183 \mathrm{~cm}$, MIS3. o) Palmoconcha guttata (Norman, 1865), male LV, ZTF720, Recent. p) Palmoconcha laevata (Norman, 1865), female LV, 1558, KS05-215 cm, MIS3. q) Sagmatocythere multifora (Norman, 1865), male LV, ZTF744, Recent. r) Sagmatocythere aff. multifora (Norman, 1865), female RV, 1524, KS05-241 cm, MIS3. 
1985 Leptocythere macallana; Guillaume et al., pl. 107, figs 14, 15. (Recent, intertidal shelf of Bay of Biscay).

1989 Leptocythere macallana; Athersuch et al., p. 103, fig. 37; pl. 1, fig. 9. (Recent, NW European coasts, and Mediterranean. Shallow waters in sands with algae).

2013 Leptocythere macallana; Cabral \& Loureiro, pl. 5, fig. 11. (Holocene, Portugal).

Distribution. This species is only found in few Recent samples of the Basque shelf.

\section{Leptocythere pellucida (Baird, 1850)}

(Figs 7i, 7j)

1979 Leptocythere pellucida; Yassini, pl. 3, fig. 2. (Recent, Algerian coastal bay).

1985 Leptocythere pellucida; Guillaume et al., pl. 107, figs 1, 2. (Recent, intertidal shelf of Bay of Biscay).

1989 Leptocythere pellucida; Athersuch et al., p. 96, fig. 33; pl. 1, figs 3-4. (Recent, NW European coasts, from France to the Baltic Sea and Norway. Marine sublittoral $(<50 \mathrm{mwd})$ in sands with algae $)$.

2013 Leptocythere pellucida; Cabral \& Loureiro, pl. 5, fig. 12. (Holocene, Portugal).

Distribution. In the Basque shelf this species has been recorded only in few MIS3 and Holocene samples.

Family Loxoconchidae Sars, 1925

Genus Elofsonia Wagner, 1957

Type species Elofsonia baltica (Hirschmann, 1909)

Elofsonia pusilla (Brady \& Robertson, 1870) (Fig. 7k)

1989 Elofsonia pusilla; Athersuch et al., p. 184, fig. 73; pl. 6, fig. 2. (Recent, British Isles. Marine in sandy substrates and brackish water in Baltic Sea and Gulf of Finland).

2013 Elofsonia pusilla; Cabral \& Loureiro, pl. 5, fig. 20. (Holocene, Portugal).

Distribution. This species is only present in the Recent of the Basque shelf.

Genus Loxoconcha Sars, 1866
Type species Loxoconcha rhomboidea (Fischer, 1855) Sars, 1866

\section{Loxoconcha elliptica Brady, 1868}

(Fig. 71)

1976a Loxoconcha elliptica; Athersuch \& Whittaker, vol. 3 (19), p. 99-106. (Recent. British Isles. Brackish pool).

1976 Loxoconcha elliptica; Bonaduce et al., pl. 67, fig. 10. (Recent, Adriatic Sea).

1987 Loxoconcha elliptica; Aranki, pl. 20, figs 7, 8; pl. 21, figs 1-5. (Recent. S Spain. Lagoon, living).

1989 Loxoconcha elliptica; Athersuch et al., p. 176, fig. 70; pl. 5, fig. 8. (Recent. NW Europe and Mediterranean. Brackish water of estuaries, lagoons and pools with algae and mud).

1994 Loxoconcha elliptica; Ruíz Muñoz, pl. 6, figs 9-11. (Recent, estuaries, Huelva, S Spain).

2013 Loxoconcha elliptica; Cabral \& Loureiro, pl. 6, fig. 3. (Recent, estuarine living, continental shelf of Algarve and Holocene, Portugal).

Distribution. This species is found in early Holocene and Recent sediments of the inner Basque shelf $(<110$ mwd).

\section{Loxoconcha rhomboidea (Fischer, 1855)}

(Fig. $7 \mathrm{~m}$ )

1972 Loxoconcha rhomboidea; Uffenorde, pl. 8, fig. 10. (Recent, N Adriatic Sea).

1976b Loxoconcha rhomboidea; Athersuch \& Whittaker, vol. 3 (17), p. 81-90. (Recent. S Norway. Brackish pool).

1976 Loxoconcha rhomboidea; Bonaduce et al., pl. 59, figs 8-12. (Recent, Adriatic Sea).

1979 Loxoconcha rhomboidea; Yassini, pl. 6, figs 3, 4. (Recent, Algerian coastal bay).

1985 Loxoconcha rhomboidea; Guillaume et al., pl. 102, figs 9, 10; pl. 109, figs 7-9. (Recent, Bay of Biscay. Intertidal and subtidal).

1989 Loxoconcha rhomboidea; Athersuch et al., p. 174, fig. 69; pl. 5, fig. 7. (Recent. Coasts of Norway to Canary and Madeira Islands. Marine sublittoral phytal and outer estuarine).

1994 Loxoconcha rhomboidea; Ruíz Muñoz, pl. 7, figs 1, 2. (Recent, shelf, Huelva, S Spain). 
2013 Loxoconcha rhomboidea; Cabral \& Loureiro, pl. 6, fig. 5. (Recent, littoral -outer estuarine and rockpool living-, continental shelf and slope of Algarve and Holocene, Portugal).

Distribution. This species is regularly present in the Basque shelf during the interval MIS3 to Recent.

Loxoconcha sp. 1 aff. Loxoconcha linleyi Horne, 1982 (Fig. 7n)

1982 Loxoconcha linleyi; Horne, 9 (6), p. 33-40. (Recent, Canary Islands. Intertidal).

Distribution. This species has been so far found in MIS3 of the outer Basque shelf. A doubtful record has been done in mid-late Holocene of the inner shelf.

Genus Palmoconcha Swain \& Gilby, 1974

Type species Palmoconcha laevimarginata (Swain \& Gilby, 1974)

Palmoconcha guttata (Norman, 1865)

(Fig. 7o)

1981 Lindisfarnia guttata; Athersuch \& Horne, 8 (20), p. 117-124. (Recent, NE England. Sublittoral).

1985 Loxoconcha guttata; Guillaume et al., pl. 102, figs 3 , 4. (Recent, Bay of Biscay. Subtidal to outer shelf).

1989 Palmoconcha guttata; Athersuch et al., p. 188, fig. 75; pl. 6, figs 5, 6. (Recent. NW Europe coastal waters $-10-90 \mathrm{mwd})$.

1994 Palmoconcha guttata; Ruíz Muñoz, pl. 7, figs 3-6. (Recent, shelf, Huelva, S Spain).

2013 Palmoconcha guttata; Cabral \& Loureiro, pl. 6, fig. 8. (Recent, continental shelf and slope of Algarve and Holocene, Portugal).

2015 Palmoconcha guttata; Martínez-García et al., pl. 1, fig. 19. (Late Quaternary, Basque shelf).

Distribution. This species is regularly present in the Basque shelf during the interval MIS3 to Recent. It can be found living in any type of substrate in the shelf, being more abundant in depth interval of 90-150 mwd.

\section{Palmoconcha laevata (Norman, 1865)}

(Fig. 7p)

1979 Loxoconcha turbida Müller; Yassini, pl. 6, figs 5,

7. (Recent, Algerian coastal bay).
1981 Lindisfarnia laevata; Horne \& Kilenyi, 8 (19), p. 107-116. (Recent, NE England. Sublittoral).

1989 Palmoconcha laevata; Athersuch et al., p. 190, fig. 76; pl. 6, fig. 4. (Recent. NW Europe coastal waters $-0-90 \mathrm{mwd})$.

2013 Palmoconcha laevata; Cabral \& Loureiro, pl. 6, fig. 9. (Recent, continental slope of Algarve and Holocene, Portugal).

Distribution. This species is regularly present in the Basque shelf during the interval MIS3 to Recent.

Genus Sagmatocythere Athersuch, 1976

Type species Sagmatocythere napoliana (Puri, 1963)

Sagmatocythere multifora (Norman, 1865)

(Fig. 7q)

1979 Loxoconcha multiflora; Yassini, pl. 6, figs 10, 11. (Recent, Algerian coastal bay).

2013 Sagmatocythere multifora; Cabral \& Loureiro, pl. 6, fig. 13. (Recent, continental shelf and slope of Algarve and Holocene, Portugal).

Distribution. In the Basque shelf, this species has been only recorded in the Recent.

Sagmatocythere aff. multifora (Norman, 1865)

(Fig. 7r)

aff. 1989 Sagmatocythere multifora; Athersuch et al., p. 194, fig. 78; pl. 6, fig. 7.

aff. 2013 Sagmatocythere multifora; Cabral \& Loureiro, pl. 6, fig. 13. (Recent, continental shelf and slope of Algarve and Holocene, Portugal).

aff. 2015 Sagmatocythere multifora; Martínez-García et al., pl. 1, fig. 23. (Late Quaternary, Basque shelf).

Distribution. This species is present in the interval MIS3 to Recent in the Basque Basin.

Sagmatocythere variesculpta (Ruggieri, 1962)

(Fig. 8a)

1993 Loxocorniculum multireticulatum Maybury, p. 101, pl. 20, figs 1-3. (Upper Pliocene, France).

2009 Sagmatocythere variesculpta; Whittaker \& Horne, pl. 3, figs 16, 17. (MIS13 to ?MIS5e. CircumMediterranean distribution from the Pliocene. Supposedly extinct). 

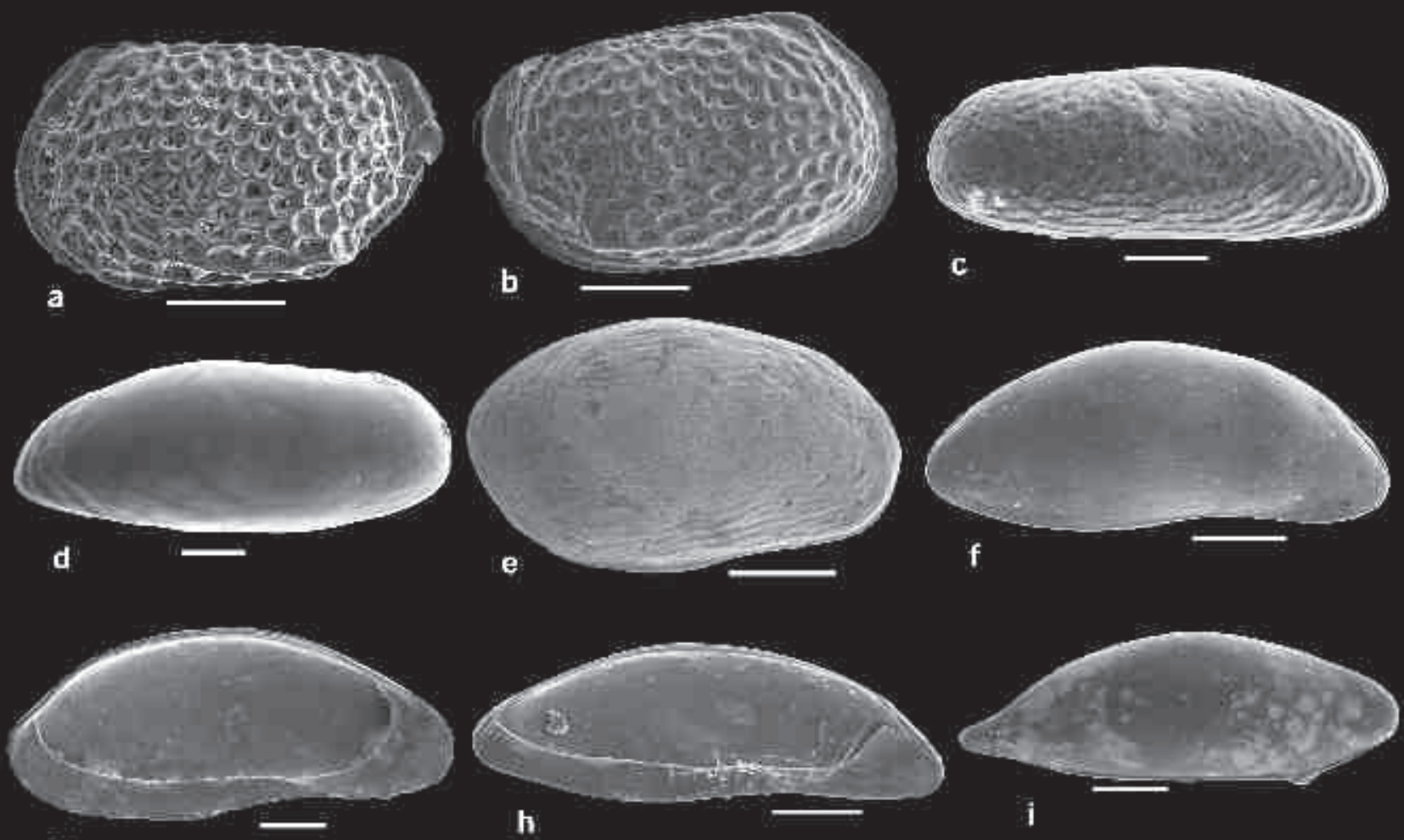

g
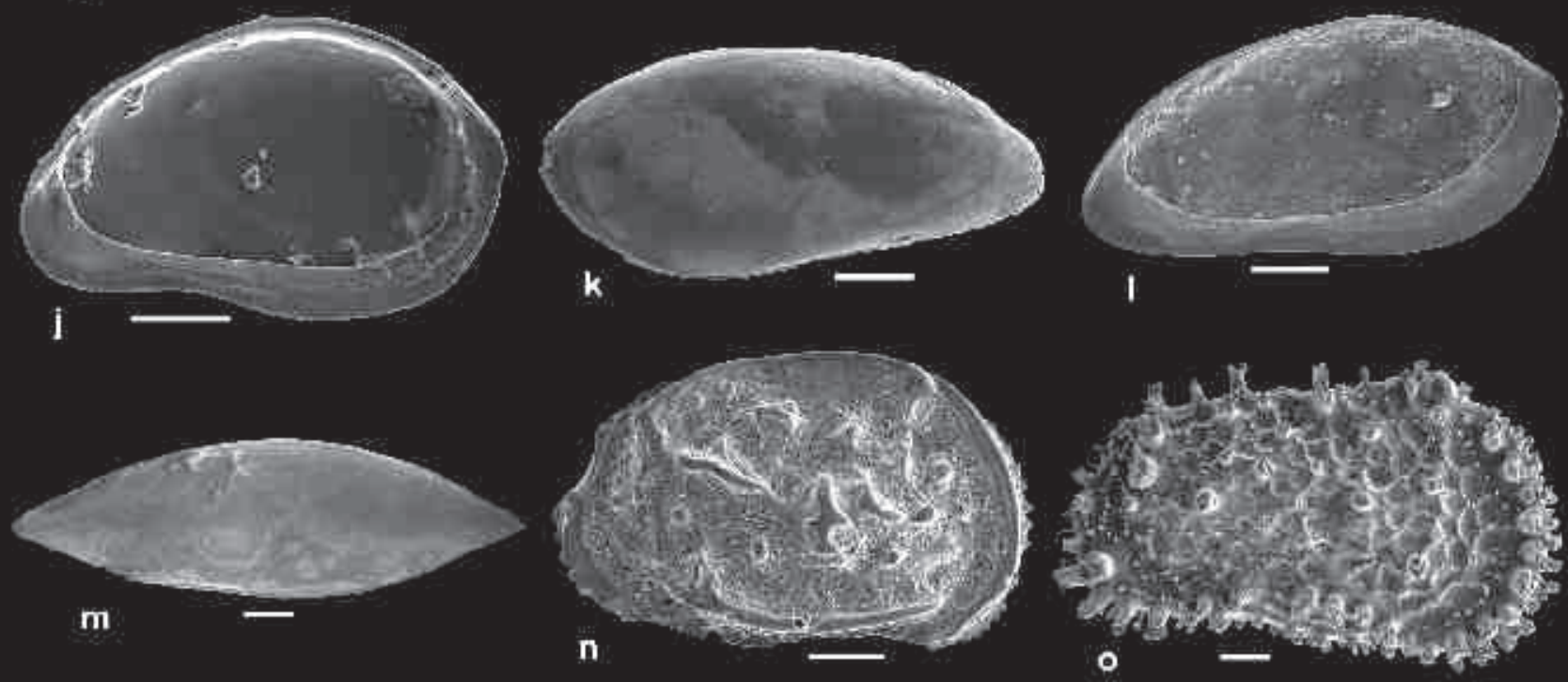

I Ting

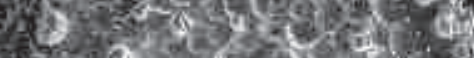

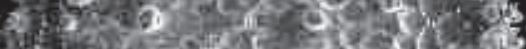

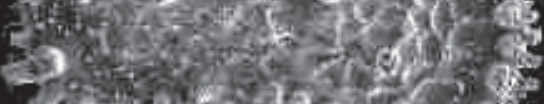
- 2 -
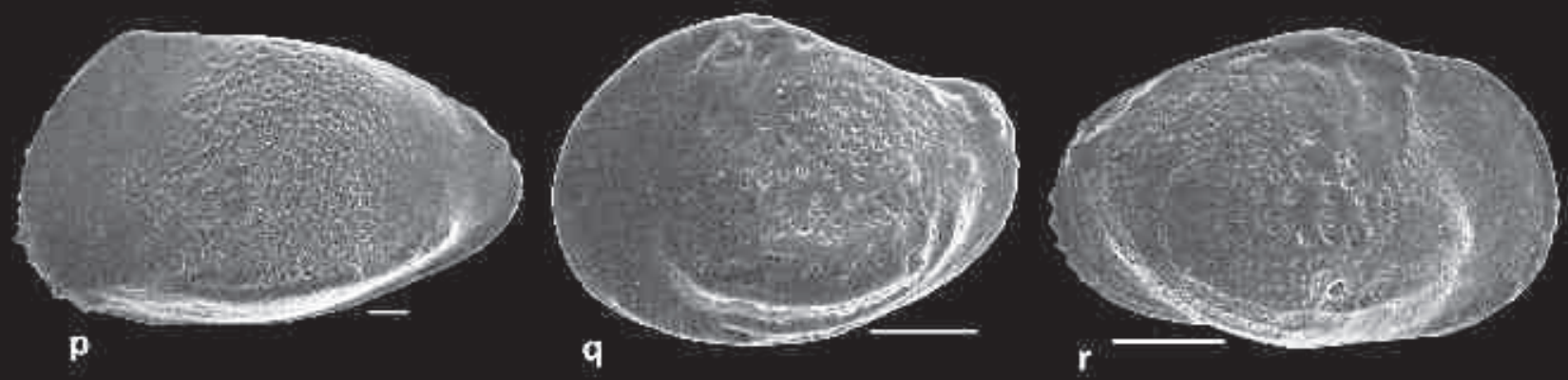
2013 Sagmatocythere variesculpta; Cabral \& Loureiro, pl. 6, fig. 17. (Holocene, Portugal).

Distribution. This species has been recorded in the Recent of the Basque shelf.

Sagmatocythere aff. variesculpta (Ruggieri, 1962) (Fig. 8b)

1986 Sagmatocythere aff. variesculpta; Ciampo, pl. 5, fig. 8. (Upper Miocene, Italy).

Distribution. This species has been recorded in the Recent of the Basque shelf.

Family Neocytherideidae Puri, 1957

Genus Neocytherideis Puri, 1952

Type species Neocytherideis elongata Puri, 1952

Neocytherideis subulata (Brady, 1868)

(Figs 8c, 8d)

1976 Neocytherideis fasciata (Brady \& Robertson, 1874); Bonaduce et al., p. 62, pl. 35, figs 6-10.

(Recent, Adriatic Sea).

1976 Neocytherideis fasciata; Breman, pl. 6, fig. 79. (Recent, Adriatic Sea).

1979 Neocytherideis faveolata; Yassini, pl. 4, fig. 11. (Recent, Algerian coastal bay).

1982 Neocytherideis subulata; Athersuch, p. 233, pl. 1, figs 1-11; figs 1a-1g.

1985 Neocytherideis subulata; Guillaume et al., pl. 108, figs 3-5. (Recent, intertidal of Bay of Biscay).

1985 Neocytherideis fasciata; Guillaume et al., pl. 100, figs 1, 2. (Recent, intertidal of Cap Breton).

1987 Neocytherideis fasciata; Aranki, pl. 17, fig. 11. (Recent, S Spain, coastal - $12 \mathrm{mwd}$ ).
1989 Neocytherideis subulata; Athersuch et al., p. 122, fig. 48; pl. 3, fig. 7. (Recent, British Isles and coasts of France. Sublittoral and inner shelf in fine sand sediments).

1994 Neocytherideis subulata; Ruíz Muñoz, pl. 3, figs 3, 4. (Recent, shelf, Huelva, S Spain).

2013 Neocytherideis subulata; Cabral \& Loureiro, pl. 7, fig. 1. (Recent, continental shelf of Algarve and Holocene, Portugal).

Distribution. This species is present in the Holocene of the Basque shelf. In Recent sediments it is occurring in fine substrates 50 to $150 \mathrm{mwd}$. Doubtful record in MIS3 in the outer shelf.

Family Paradoxostomatidae Brady \& Norman,
1889

Genus Brunneostoma Schornikov, 1993

Type species Brunneostoma brunneum (Schornikov, 1974) Schornikov, 1993

\section{Brunneostoma sp.}

(Fig. 8e)

Distribution. In this material Brunneostoma sp. are scarcely represented in the Recent and MIS2 of the Basque shelf.

Genus Paracytherois G.W. Müller, 1894

Type species Paracytherois flexuosa (Brady, 1867)

Paracytherois flexuosa (Brady, 1867)

(Figs 8f, 8g)

1976 Paracytherois flexuosa; Bonaduce et al., pl. 71, fig. 6. (Recent, Adriatic Sea).

1989 Paracytherois flexuosa; Athersuch et al., p. 314, fig. 137. (Recent, British Isles).

Figure 8. Ostracods from the Basque Basin. a) Sagmatocythere variesculpta (Ruggieri, 1962), female LV, ZTF743, Recent. b) Sagmatocythere aff. variesculpta (Ruggieri, 1962), female RV, FCT646, Recent. c) Neocytherideis subulata (Brady, 1868), juvenile RV, FCT649, Recent. d) Neocytherideis subulata (Brady, 1868), LV, ZTF728, Recent. e) Brunneostoma sp., RV, FCT656, Recent. f) Paracytherois flexuosa (Brady, 1867), C right view, FCT655, Recent. g) Paracytherois flexuosa (Brady, 1867), LV interior, 71-34, KS16-111 cm, MIS2. h) Paracytherois sp. 1, LV interior, FCT667, Recent. i) Paracytherois sp. 2, RV, FCT686, Recent. j) Paradoxostoma aff. abbreviatum Sars, 1866, female RV interior, ZTF736, Recent. k) Paradoxostoma ensiforme Brady, 1868, RV, ZTF733, Recent. I) Paradoxostoma variabile (Baird, 1835), RV interior, FCT684, Recent. m) Paradoxostoma tenuissimum (Norman, 1869), LV, 90-57, KS05-142 cm, Early Holocene. n) Thaerocythere hoptonensis (Brady, Crosskey \& Robertson, 1874), female RV, ZTF747, Recent. o) Actinocythereis dunelmensis (Norman, 1865), RV, 1504, KS05-241 cm, MIS3. p) Bosquetina tarentina (Baird, 1850), male LV, 82-16, KS05-240 cm, MIS3. q) Buntonia sublatissima (Neviani, 1906), LV, 82-15, KS05-240 cm, MIS3. r) Buntonia textilis Bonaduce, Ciampo \& Masoli, 1975, RV, 81-49, KS16-60 cm, MIS2. 
2013 Paracytherois flexuosa; Cabral \& Loureiro, pl. 8 , fig. 2. (Recent, outer estuarine, Portugal).

Distribution. In the Basque Basin, this species has been recorded in MIS2 and Recent sediments of the outer shelf (130-150 mwd).

\section{Paracytherois sp. 1}

(Fig. 8h)

2009 Paracytherois sp.; Yasuhara et al., pl. 19, figs

1-4. (Latest Quaternary, W Atlantic. Deep marine).

Distribution. This species has been recorded in upper bathyal sediments of the Bay of Biscay.

\section{Paracytherois sp. 2}

(Fig. 8i)

1976 Paradoxostoma acuminatum; Bonaduce et al., pl. 71, fig. 14. (Recent, Adriatic Sea).

Distribution. This species has been recorded in Recent sediments of the outer Basque shelf and epibathyal Bay of Biscay.

Genus Paradoxostoma Fischer, 1855

Type species Paradoxostoma dispar Fischer, 1855

Paradoxostoma aff. abbreviatum Sars, 1866

(Fig. 8j)

aff. 1985b Paradoxostoma abbreviatum; Horne \& Whittaker, p. 138, pl. 39, figs A, B.

aff. 1989 Paradoxostoma abbreviatum; Athersuch et al., p. 278, pl. 119, figs A, B. (Recent, British Isles, Norway, Baltic, France. Littoral to sublittoral, in algae).

2011 Paradoxostoma abbreviatum; Faranda \& Gliozzi, fig. 14a. (Early Pleistocene, Mediterranean).

2013 Paradoxostoma aff. abbreviatum; Cabral \& Loureiro, pl. 7, fig. 13. (Recent, outer estuarine and Holocene, Portugal).

Distribution. This species is common in this basin, being recorded in the interval MIS3 to Recent in the Basque shelf. Nowadays it can be found in very fine sands (73-83 mwd). Also recorded in MIS3 of bathyal Bay of Biscay.

Paradoxostoma ensiforme Brady, 1868

(Fig. 8k)
1979 Paradoxostoma triste; Yassini, pl. 11, figs 1, 2. (Recent, Algerian coastal bay).

1985b Paradoxostoma ensiforme; Horne \& Whittaker, p. 149, pl. 38, figs E, F.

2011 Paradoxostoma ensiforme; Faranda \& Gliozzi, fig. 14a. (Pleistocene, Mediterranean).

2013 Paradoxostoma ensiforme; Cabral \& Loureiro, p. 147, pl. 7, fig. 15. (Recent, outer estuarine and Holocene, Portugal).

2014 Lanceostoma simplex Meireles \& Keyser; Meireles et al., p. 23, pl. 5, figs d-f. (Holocene, Azores. Shallow marine).

Distribution. In this material this species is only scarcely represented in the Recent of the Basque shelf.

Paradoxostoma variabile (Baird, 1835)

(Fig. 81)

1985b Paradoxostoma variabile; Horne \& Whittaker, p. 188 , figs $45 \mathrm{~A}-\mathrm{C}$.

1989 Paradoxostoma variabile; Athersuch et al., p. 306, fig. 133. (Bristish Isles, Norway, Sweden, Baltic Sea and N France. Littoral to sublittoral marine and estuarine, with algae).

Distribution. This species is only scarcely represented in the mid-late Holocene and Recent of the Basque shelf and epibathyal Bay of Biscay.

Paradoxostoma tenuissimum (Norman, 1869)

(Fig. 8m)

1976 Machaerina tenuissima; Bonaduce et al., pl. 71, fig. 9. (Recent, Adriatic Sea).

1985b Paradoxostoma tenuissimum; Horne \& Whittaker, p. 188, figs 44D-E, 45D-E.

2011 Paradoxostoma tenuissimum; Faranda \& Gliozzi, fig. 16a. (Early Pleistocene, Mediterranean).

2013 Paradoxostoma tenuissimum; Cabral \& Loureiro, pl. 7, fig. 19. (Recent, continental shelf, Portugal).

Distribution. In this material this species is very scarcely represented in the MIS3 and early Holocene of the Basque shelf.

Family Thaerocytheridae Hazel, 1967

Genus Thaerocythere Hazel, 1967 
Type species Thaerocythere crenulata (Sars, 1866)

Thaerocythere hoptonensis (Brady, Crosskey \& Robertson, 1874)

(Fig. 8n)

1994 Thaerocythere lusitanica; Ruíz Muñoz, p. 176, pl. 5, figs. 5, 6. (Recent, shelf, Huelva (S Spain). Fine to very fine sands $-5-16 \mathrm{mwd}$ ).

1997 Thaerocythere hoptonensis; Wood \& Whatley, p. 12, pl. 2, figs 6-8. (Pliocene to Recent, East N Atlantic, British Isles to Morocco).

2013 Thaerocythere hoptonensis; Cabral \& Loureiro, pl. 8, fig. 5. (Recent, outer estuarine, continental shelf of Algarve and Holocene, Portugal).

Distribution. This species is rarely found in the Recent of the Basque shelf. Doubtful record in late Holocene of the inner Basque shelf.

Family Trachyleberididae Sylvester-Bradley, 1948

Genus Actinocythereis Puri, 1953b

Type species Cythere exanthemata (Ulrich \& Bassler, 1904)

Actinocythereis dunelmensis (Norman, 1865)

(Fig. 8o)

1981 Acanthocythereis dunelmensis; Cronin, pl. 8, figs 1, 2. (Late Pleistocene, Champlain Sea).

1988 Acanthocythereis dunelmensis; Cronin, pl. 2, fig. 9. (Pleistocene, postglacial NW Atlantic).

1989 Acanthocythereis dunelmensis; Athersuch et al., p. 133, fig. 52; pl. 3, fig. 10. (Recent, British Isles, Norway, Greenland. Marine, sublittoral - 50-100 mwd).

2006 Acanthocythereis dunelmensis; Schornikov \& Zenina, pl. 2, figs 13-15. (Recent, Arctic Ocean).

2015 Acanthocythereis dunelmensis; Martínez-García et al., pl. 1, fig. 1. (Late Quaternary, Basque shelf).

Remarks. This species has been traditionally included in Acanthocythereis Howe, 1963, but recently it has been changed to genus Actinocythereis by Brandão et al. (2017).

Distribution. This species is regularly present in the Basque shelf during the interval MIS3 to Recent.

Genus Bosquetina Keij, 1957
Type species Bosquetina pectinata (Bosquet, 1852) Keij, 1957

$$
\text { Bosquetina tarentina (Baird, 1850) }
$$

(Fig. 8p)

1976 Bosquetina dentata; Bonaduce et al., p. 48, pl. 31, figs 9-10. (Recent, Adriatic Sea).

1985 Bosquetina dentata; Guillaume et al., pl. 103, figs 9, 10. (Recent, circalittoral of Bay of Biscay).

2013 Bosquetina tarentina; Cabral \& Loureiro, pl. 8, fig. 7. (Recent, continental shelf of Algarve -livingand Holocene, Portugal).

Distribution. B. tarentina is regularly present in the Basque shelf from MIS3 to the present, being alive in the outer shelf in waters deeper than $126 \mathrm{mwd}$ in all kind of sediments.

Genus Buntonia Howe, 1935

Type species Buntonia shubutaensis Howe \& Chambers, 1935

\section{Buntonia sublatissima (Neviani, 1906)}

(Fig. 8q)

1976 Buntonia sublatissima; Bonaduce et al., pl. 33, figs 6-8. (Recent, Adriatic Sea).

2013 Buntonia sublatissima; Cabral \& Loureiro, pl. 8, fig. 8. (Recent, continental shelf and slope of Algarve, Portugal).

Distribution. This species is scarce in the Basque outer shelf during MIS3 and Recent.

Buntonia textilis Bonaduce, Ciampo \& Masoli, 1976 (Fig. 8r)

1976 Buntonia textilis; Bonaduce et al., p. 55, pl. 33, figs 1-5. (Recent, Adriatic Sea).

1980 Buntonia textilis; Colalongo \& Pasini, pl. 2, figs 5, 6. (Pleistocene, deep marine, Vrica, Calabria, Italy).

2013 Buntonia textilis; Cabral \& Loureiro, pl. 8, fig. 9. (Recent, continental slope of Algarve, Portugal).

2014 Buntonia textilis; Yasuhara et al., pl. fig. 7, figs 3, 4. (Recent, Icelandic deep-sea waters).

2015 Buntonia textilis; Yasuhara et al., figs 31A-E.

(Pleistocene, NE Atlantic. Deep marine). 
2015 Buntonia textilis; Martínez-García et al., pl. 1, fig. 5. (Late Quaternary, Basque shelf).

Distribution. This species is occurring in the Basque shelf during the interval MIS3 to Recent. It can be found in all type of substrates, mainly in silty sand in waters deeper than $140 \mathrm{~m}$.

Genus Carinocythereis Ruggieri, 1956

Type species Carinocythereis carinata (Roemer, 1838)

\section{Carinocythereis carinata (Roemer, 1838)}

(Fig. 9a)

1976 Carinocythereis antiquata antiquata; Breman, pl. 8, fig. 103. (Recent, Adriatic Sea).

1979 Carinocythereis antiquata; Yassini, pl. 5, figs 12, 13. (Recent, Algerian coastal bay).

1980 Carinocythereis carinata; Ruggieri \& Russo, pl. 2, fig. 8. (Upper Miocene, Italy).

1987a Carinocythereis carinata; Athersuch \& Whittaker, 14 (23), p. 97-102. (Late Pliocene, N Italy).

1989 Carinocythereis carinata; Athersuch et al., p. 136, fig. 53; pl. 4, fig. 1. (Recent, British Isles, Atlantic coast of France, Mediterranean. Marine sublittoral, 2-60 mwd).

2006 Carinocythereis carinata; Mostafawi \& MatzkeKarasz, pl. 1, fig. 1. (Pliocene, Greece) [For a complete synonymy].

2013 Carinocythereis carinata; Cabral \& Loureiro, pl. 8, fig. 10. (Recent, continental shelf and slope of Algarve, Portugal.).

2015 Carinocythereis carinata; Martínez-García et al., pl. 1, fig. 6. (Late Quaternary, Basque shelf).

Distribution. C. carinata is a common species in this basin, from the MIS3 to the present time, where it can be found alive in fine sediments of inner and outer shelf.

\section{Carinocythereis whitei (Baird, 1850)}

(Fig. 9b)

1976 Carinocythereis antiquata; Bonaduce et al., pl. 25, figs 8-10. (Recent, Adriatic Sea).

1976 Carinocythereis antiquata bairdi Uliczny; Breman, pl. 8, fig. 104. (Recent, Adriatic Sea).

1979 Carinocythereis carinata carinata; Yassini, pl. 4, fig. 12. (Recent, Algerian coastal bay).
1985 Carinocythereis carinata; Guillaume et al., pl. 109, figs 2-6. (Recent, outer shelf of Bay of Biscay).

1987b Carinocythereis whitei; Athersuch \& Whittaker, 14 (24), p. 103-110. (Recent, SW Wales).

1987 Carinocythereis carinata, Carinocythereis antiquata; Aranki, pl. 5, figs 3-7. (Early Pliocene, S Spain, shelf $-10-12$ mwd).

1989 Carinocythereis whitei; Athersuch et al., p. 137, fig. 54; pl. 4, fig. 2. (Recent, British Isles, Atlantic coast of France, Mediterranean. Marine sublittoral, 2-60 mwd).

1992 Carinocythereis whitei; Bonaduce et al., pl. 14, fig. 7. (Late Miocene, Gulf of Gabès, Tunisia).

1994 Carinocythereis whitei; Ruíz Muñoz, pl. 24 fig. 3. (Recent, shelf, Huelva, S Spain).

2006 Carinocythereis carinata; Mostafawi \& MatzkeKarasz, pl. 1, figs 2, 3. (Pliocene, Greece).

2008 Carinocythereis whitei; Faranda \& Gliozzi, pl. 5, fig. 9. (Plio-Pleistocene, Roma, Italy).

2013 Carinocythereis whitei; Cabral \& Loureiro, pl. 8, fig. 11. (Recent, continental shelf and slope of Algarve and Holocene, Portugal.).

2014 Carinocythereis whitei; Meireles et al., p. 3, pl. 6, figs F-G. (Holocene, Azores. Inner shelf).

2015 Carinocythereis whitei; Martínez-García et al., pl. 1, fig. 7. (Late Quaternary, Basque shelf).

Distribution. C. whitei is regularly present in the Basque Basin from MIS3 to the present time, where it can be found in fine sediments mostly of the outer shelf.

Carinocythereis sp.

(Fig. 9c)

2008 Carinocythereis whitei; Faranda \& Gliozzi, pl.

5, fig. 9. (Plio-Pleistocene, Roma, Italy).

Remarks. This is a tuberculated form of Carinocythereis, differing from $C$. carinata and $C$. whitei by the virtual absence of lateral ridges.

Distribution. This species has been only found in few MIS3 and Recent samples of the outer Basque shelf.

Genus Celtia Neale, 1973

Type species Celtia quadridentata (Baird, 1850)

(Fig. 9d) 
1975b Celtia quadridentata; Neale, 2 (46), p. 287-294. (Pleistocene to Recent).

1979 Falunia quadridentata; Yassini, pl. 7, figs 7, 8. (Recent, Algerian coastal bay).

1985 Carinocythereis quadridentata; Guillaume et al., pl. 103, figs 3, 4. (Recent, outer shelf of Bay of Biscay).

1989 Celtia quadridentata; Athersuch et al., p. 140, fig. 55; pl. 4, fig. 3. (Recent, British Isles. Norway to the Bay of Biscay. Marine sublittoral, deeper than $75 \mathrm{~m}$ ).

2013 Celtia quadridentata; Cabral \& Loureiro, pl. 8, fig. 12. (Recent, continental shelf and slope of Algarve and Holocene, Portugal).

2015 Celtia quadridentata; Martínez-García et al., pl. 1, fig. 8. (Late Quaternary, Basque shelf).

Distribution. C. quadridentata is a common species in the interval MIS3 to Recent in the Basque shelf.

Genus Costa Neviani, 1928

Type species Costa variornata Hartmann, 1974

Costa runcinata (Baird, 1850)

(Figs 9e, 9f)

1979 Costa edwardsii; Yassini, pl. 7, figs 1, 2. (Recent, Algerian coastal bay).

1985 Costa edwardsii; Guillaume et al., pl. 102, figs 1, 2. (Recent, inner and outer shelf of Bay of Biscay).

1989 Costa runcinata; Athersuch et al., p. 142, fig. 56; pl. 4, fig. 14. (Recent, British Isles, Atlantic coasts of France and Spain, Mediterranean. Marine sublittoral 20-49 mwd, mostly on silty substrates).

1994 Costa edwardsii; Ruíz Muñoz, pl. 4, figs 4-7. (Recent, shelf, Huelva, S Spain).

2013 Costa runcinata; Cabral \& Loureiro, pl. 1, fig. 9. (Recent, continental shelf and slope of Algarve and Holocene, Portugal).

2015 Costa edwardsii; Martínez-García et al., pl. 1, fig. 9. (Late Quaternary, Basque shelf).

2015 Costa edwardsii; Sciuto \& Meli, pl. 1, fig. 7. (Pleistocene, SE Italy).

Distribution. This species has been recorded regularly in MIS3 to modern samples of the outer Basque shelf, where it is living today in fine substrates $70-140$ mwd.

Genus Rectotrachyleberis Ruggieri, 1952
Type species Rectotrachyleberis hamata (G.W. Müller, 1894)

Rectotrachyleberis punctatissima (Ruggieri, 1962) (Fig. 9g)

1973 non Costa punctatissima; Doruk, 1 (46), p. 253-256. (Upper Pliocene, Italy).

1987 Costa punctatissima; Aranki, pl. 5, fig. 10. (Early Pliocene, S Spain).

1994 Costa punctatissima; Ruíz Muñoz, p. 165, pl. 4, figs 8, 9. (Recent, shelf, Huelva, S Spain. Fine sands substrates; biocenoses deeper than $10 \mathrm{~m}$ ).

Distribution. This species has been recorded in MIS3 to modern samples of the outer Basque shelf, where it is living today.

Genus Echinocythereis Puri, 1954

Type species Echinocythereis garretti (Howe \& Mcguirt in Howe, Hadley et al., 1935)

Echinocythereis aff. echinata (Sars, 1866)

(Fig. 9h)

2009 Echinocythereis echinata; Alvarez Zarikian, pl. P9, figs 3, 4. (Late Quaternary, N Atlantic IODP 1314, deep ocean).

2013 Echinocythereis echinata; Cabral \& Loureiro, p. 157. (Recent, continental slope of Algarve, Portugal ).

2014 Echinocythereis echinata; Yasuhara \& Okahashi, pl.-fig. 8, figs 2, 3. (Late Quaternary, site 980, NE Atlantic. Deep marine, upper bathyal).

2015 Echinocythereis echinata; Yasuhara \& Okahashi, figs 16A-D. (Late Quaternary, NE Atlantic. Deep marine, upper bathyal).

2015 Echinocythereis echinata; Yasuhara et al., figs 48A-O. (Middle Miocene to Recent, N Atlantic. Deep marine).

2015 Echinocythereis echinata; Brandão \& Karanovic, fig. 2, figs A, B; fig. 3, figs A, B. (Type locality, coast of Norway, Oslo Fjord - 55-91 mwd). [For complete synonimy and updating of this species].

Distribution. E. aff. echinata is present in the Basque Basin in deep outer shelf and bathyal cores during MIS5 ( $a, b, d)$ and MIS3 to Recent. In surface samples it is found in depths of $80-130 \mathrm{~m}$, mostly in sandy substrates. 

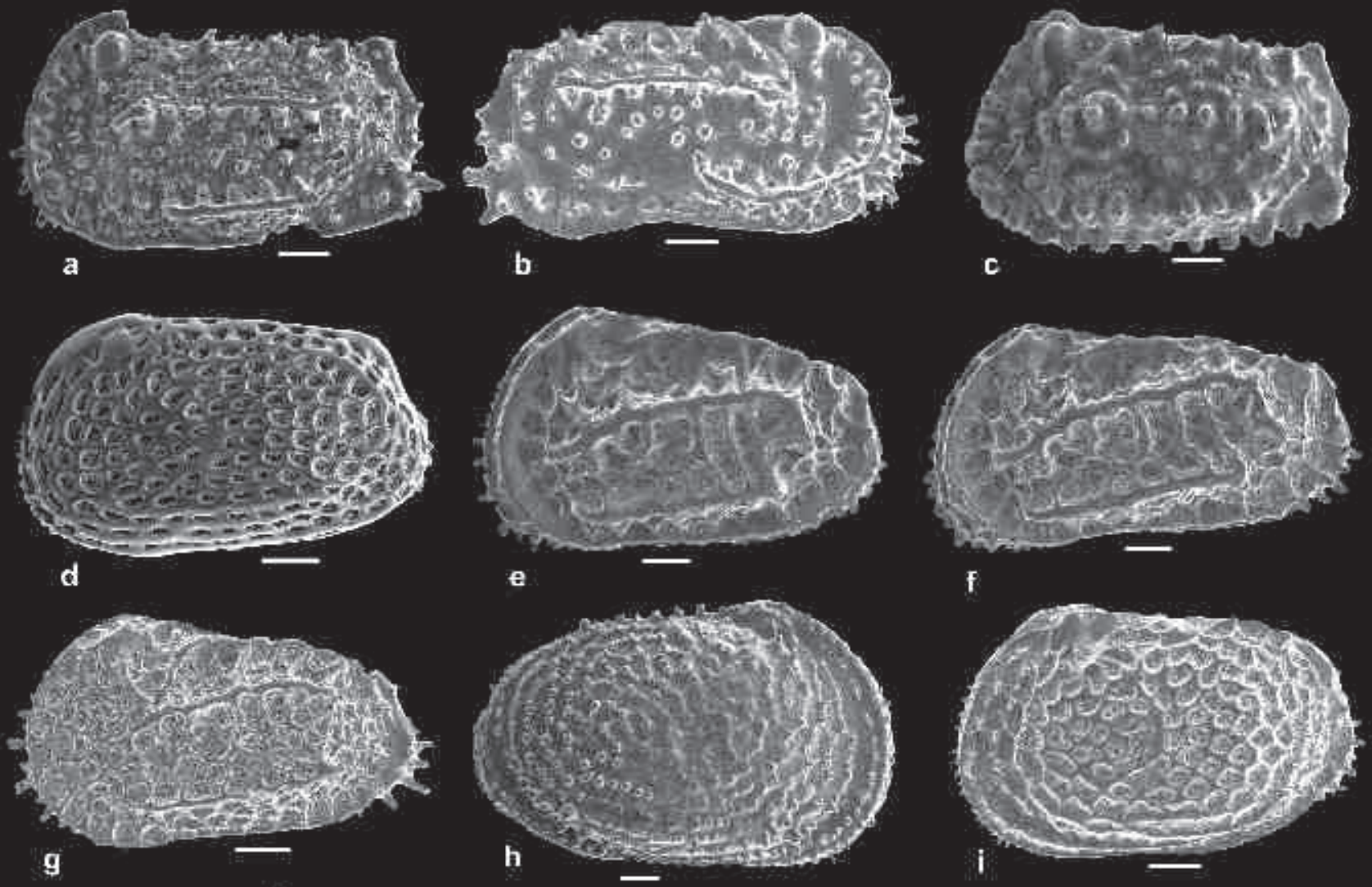

Shom

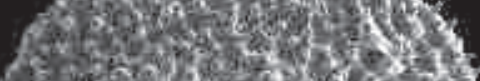

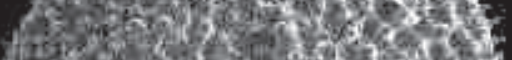

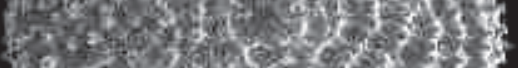

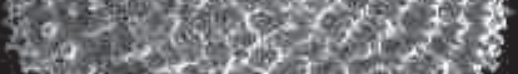

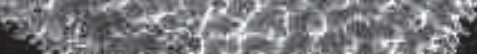

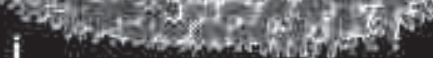
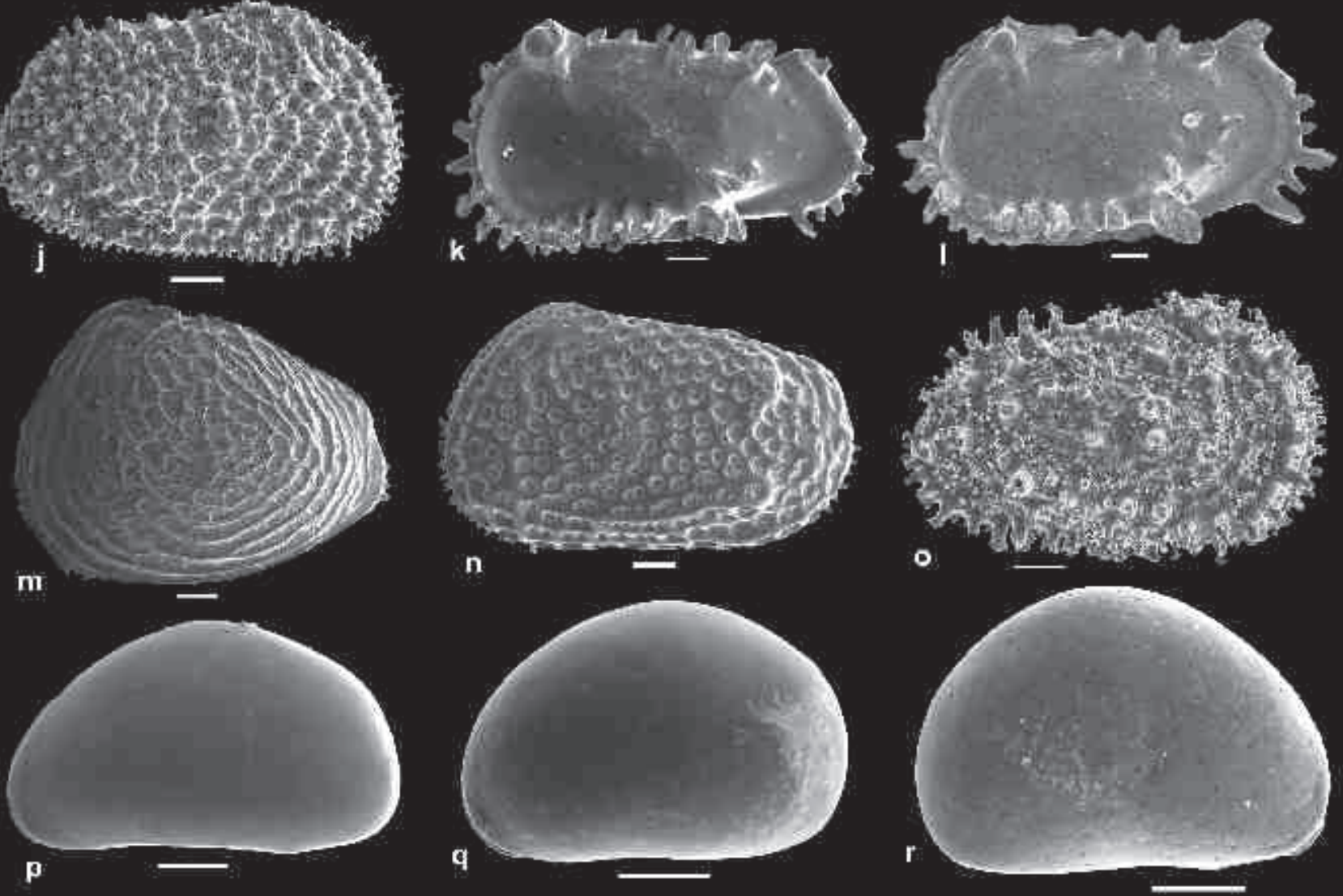


\section{Echinocythereis laticarina (Brady, 1868)}

(Fig. 9i)

1976 Echinocythereis laticarina; Bonaduce et al., p. 52, pl. 61, fig. 11. (Recent, Adriatic Sea).

1979 Echinocythereis laticarina; Yassini, pl. 12, figs 3-4. (Recent, Algerian coastal bay).

1985 Echinocythereis laticarina; Guillaume et al., pl. 104, figs 7-8. (Recent, circalittoral-epibathyal of Bay of Biscay).

Distribution. This species is regularly present in the Basque shelf during the interval MIS3 to Recent.

Genus Henryhowella Puri, 1957

Type species Cythere evax Ulrich \& Bassler, 1904

$$
\text { "Henryhowella" sp. }
$$

(Fig. 9j)

2009 Henryhowella dasyderma; Alvarez Zarikian, pl. P9, figs 6-8. (Late Quaternary, N Atlantic IODP 1314, deep ocean).

2013 Henryhowella spp.; Brandão \& Yasuhara, pl. 2, figs a, b, d. (Challenger station 296. Fig. c, station 302. SE Pacific. Off Chile, deep ocean - 3338 mwd).

2015 Henryhowella dasyderma; Alvarez Zarikian, pl. 10, figs 7, 8. (Pleistocene, S Pacific. IODP 329. Deep ocean).

Remarks. Brandão \& Yasuhara (2013) included Henryhowella dasyderma (Brady, 1880) in the genus Ayressoleberis Brandão \& Yasuhara, 2013. Morphologically "Henryhowella" sp. is very close to $A$. dasyderma, but we let it in open nomenclature waiting for a more complete study.

Distribution. This species has been found in MIS3 and mid-late Holocene to Recent in the outer Basque shelf. In surface samples it occurs in very fine sands 130-150 mwd.
Genus Pterygocythereis Blake, 1933

Type species Pterygocythereis jonesii (Baird, 1850)

Pterygocythereis ceratoptera (Bosquet, 1852)

(Fig. 9k)

1976 Pterygocythereis ceratoptera; Bonaduce et al., p. 53, pl. 30, figs 1-2. (Recent, Adriatic Sea. Shelf, 71-160 mwd in fine sands and silts).

2013 Pterygocythereis ceratoptera; Cabral \& Loureiro, pl. 8, fig. 18. (Recent, continental shelf of Algarve, Portugal).

2015 Pterygocythereis ceratoptera; Martínez-García et al., pl. 1, fig. 21. (Late Quaternary, Basque shelf).

Distribution. $P$. ceratoptera is a dominant species in these assemblages. It has been regularly recorded from MIS3 to the modern Basque shelf, where it is living at 90 to $152 \mathrm{mwd}$.

Pterygocythereis jonesii (Baird, 1850)

(Fig. 91)

1976 Pterygocythereis jonesii; Bonaduce et al., p. 54, pl. 29, figs 1-2. (Recent, Adriatic Sea. Shelf, optimum 80-170 mwd in fine sands to silts).

1978 Pterygocythereis jonesii; Athersuch, p. 9-16.

1979 Pterygocythereis jonesii; Yassini, pl. 4, fig. 1. (Recent, Algerian coastal bay).

1985 Pterygocythereis jonesii; Guillaume et al., pl. 103, figs 7-8. (Recent, circalittoral of Bay of Biscay).

1989 Pterygocythereis jonesii; Athersuch et al., p. 146, fig. 58; pl. 4, fig. 6. (Recent. British Isles, Denmark, French and Spainish coasts, Mediterranean. Marine sublittoral up to $200 \mathrm{mwd}$ ).

2008 Pterygocythereis jonesii; Faranda \& Gliozzi, pl. 7, fig. 2. (Plio-Pleistocene, Roma, Italy).

Figure 9. Ostracods from the Basque Basin. a) Carinocythereis carinata (Roemer, 1838), female LV, ZTF666, Recent. b) Carinocythereis whitei (Baird, 1850), male RV, 81-30, KS05-183 cm, MIS3. c) Carinocythereis sp., LV, ZTF664, Recent. d) Celtia quadridentata (Baird, 1850), LV, 1512, KS05-24 cm, MIS3. e) Costa runcinata (Baird, 1850), female LV, 82-26, KS05-210 cm, MIS3. f) Costa runcinata (Baird, 1850), male LV, 82-28, KS05-210 cm, MIS3. g) Rectotrachyleberis punctatissima (Ruggieri, 1962), LV, 81-28, KS10-183 cm, Early Holocene. h) Echinocythereis aff. echinata (Sars, 1866), RV, 1566, KS05$187 \mathrm{~cm}$, MIS3. i) Echinocythereis laticarina (Brady, 1868), LV, 81-27, KS10-183 cm, Early Holocene. j) "Henryhowella" sp., RV, 1539, KS05-231 cm, MIS3. k) Pterygocythereis ceratoptera (Bosquet, 1852), LV, 1502, KS05-241 cm, MIS3. l) Pterygocythereis jonesii (Baird, 1850), LV, 82-29, KS05-210 cm, MIS3. m) Rabilimis mirabilis (Brady, 1868) Hazel, 1967, LV, KS10-45 cm, Holocene. n) Robertsonites cf. tuberculatus (Sars, 1866), female LV, 1564, KS05-187 cm, MIS3. o) Trachyleberis? sp., RV, 81-54, KS16-71 cm, MIS2. p) Xestoleberis aff. dispar G.W. Müller, 1894, LV, ZTF783, Recent. q) Xestoleberis aff. rubens Whittaker, 1978, LV, ZTF776, Recent. r) Xestoleberis sp., RV, 1529, KS05-241 cm, MIS3. 
2013 Pterygocythereis jonesii; Cabral \& Loureiro, pl. 8, fig. 19. (Recent, continental shelf and slope of Algarve and Holocene, Portugal).

2015 Pterygocythereis jonesii; Martínez-García et al., pl. 1, fig. 22. (Late Quaternary, Basque shelf).

Distribution. P. jonesii is another dominant species in these assemblages. It has been regularly recorded from MIS3 to the modern Basque shelf, where it is living at depths more than $90 \mathrm{~m}$ in all type of substrates, more preferably in fine sediments.

Genus Rabilimis Hazel, 1967

Type species Rabilimis mirabilis (Brady, 1868)

Hazel, 1967

Rabilimis mirabilis (Brady, 1868) Hazel, 1967

(Fig. 9m)

2000 Rabilimis mirabilis; Didié \& Bauch, pl. 4, fig.

8. (MIS4, NE Atlantic).

2007 Rabilimis mirabilis; Stepanova et al., pl. 3, fig.

9. (Recent, Kara and Laptev Seas).

2017 Rabilimis mirabilis; Gemery et al., pl. 23, fig.

7. (Recent, Chukchi Sea, Arctic Ocean).

Distribution. This species is very rare in mid-late Holocene and Recent of the inner Basque shelf.

Genus Robertsonites Swain, 1963

Type species Robertsonites gubikensis Swain, 1963

Robertsonites cf. tuberculatus (Sars, 1866)

(Fig. 9n)

1981 Robertsonites tuberculatus; Cronin, pl. 8, fig. 5. (Late Pleistocene, Champlain Sea).

1988 Robertsonites tuberculatus; Cronin, pl. 2, fig. 10. (Pleistocene, postglacial NW Atlantic).

1989 Robertsonites tuberculatus; Athersuch et al., p. 148, fig. 59; pl. 4, fig. 7. (Recent, British Isles and Arctic. Marine sublittoral up to $75 \mathrm{mwd}$ ).

Distribution. In the Basque Basin, this species has been recorded in MIS3, MIS2 and few individuals in Recent samples of the outer shelf.

Genus Trachyleberis Brady, 1898
Type species Trachyleberis scabrocuneata (Brady, 1880) Brady, 1898

Trachyleberis? sp.

(Fig. 9o)

1997 ?Acanthocythereis coreana; Huh \& Whatley, p. 39, pl. 3, figs 6-7. (Miocene Pohang Basin, SE Korea).

2006 Acanthocythereis acanthoderma; Schornikov \& Zenina, pl. 2, fig. 15. (Recent, Arctic Ocean).

2015 "Trachyleberis" sp.; Martínez-García et al., pl.

1, fig. 25. (Late Quaternary, Basque shelf).

Remarks. This species is provisionally placed in the genus Trachyleberis?, waiting for a revision of this spinose trachyleberirid, which is morphologically close to Actinocythereis Puri, 1953b, and Croninocythereis Yasuhara et al., 2015.

Distribution. In the Basque Basin this species is regularly present in MIS3 and MIS2 in the outer shelf, while in the Holocene it is occurring in the inner shelf. Also occurring in MIS5d of the deep Bay of Biscay.

Family Xestoleberididae Sars, 1928

Genus Xestoleberis Sars, 1866

Type species Xestoleberis aurantia (Baird, 1838)

Xestoleberis aff. dispar G.W. Müller, 1894

(Fig. 9p)

1976 Xestoleberis dispar; Bonaduce et al., pl. 73, figs 1-3. (Recent, Adriatic Sea).

Distribution. This species has been recorded in the interval MIS3 to Recent in the Basque shelf. In modern samples it is found in all types of substrates up to 122 mwd.

Xestoleberis aff. rubens Whittaker, 1978

(Fig. 9q)

aff. 1978 Xestoleberis rubens sp. nov. Whittaker, p. $35-44$.

aff. 1989 Xestoleberis rubens; Athersuch et al., p. 238, fig. 101. (Recent, British Isles and Atlantic coast of France. Marine phytal).

aff. 2013 Xestoleberis rubens; Cabral \& Loureiro, 
pl. 9, fig. 7. (Recent, estuarine, continental shelf of Algarve and Holocene, Portugal).

Distribution. This species has been recorded in the interval MIS2 to Recent in the Basque shelf. In modern samples it is found in fine sand substrates $50-70 \mathrm{mwd}$.

\section{Xestoleberis $\mathrm{sp}$}

(Fig. 9r)

Distribution. In the basque Basin, this species has only been recorded in MIS3 in the outer shelf.

Taxonomic list of other species. Taxonomic list of species not included in the systematic chapter due to their scarcity in the Basque Basin. Age and distribution in the Basque Basin/Bay of Biscay are indicated.

Argilloecia acuminata G.W. Müller, 1894. MIS5 to Recent, deep bathyal Bay of Biscay.

Argilloecia sp. 2. MIS2, MIS3, deep bathyal Bay of Biscay.

Argilloecia sp. 3. MIS3, MIS4, deep bathyal Bay of Biscay.

Argilloecia sp. 4. MIS3, deep bathyal Bay of Biscay.

Australoecia cf. posteroacuta Coles \& Whatley, 1989. MIS3 and early Holocene, outer Basque shelf and MIS4, MIS2, deep bathyal Bay of Biscay.

Basslerites teres (Brady, 1869). Recent, Basque shelf.

Buntonia (Quasibuntonia) radiatopora (Seguenza, 1880). MIS5b, deep bathyal Bay of Biscay.

Bythocypris sp. MIS2, MIS4, Recent, deep bathyal Bay of Biscay.

Bythocythere eugeneschornikovi Yasuhara, Okahasi \& Cronin, 2009. MIS5c, deep bathyal Bay of Biscay. Doubtful record in Neoglacial Holocene of the outer Basque shelf.

Cytheridea acuminata? (Bosquet, 1852). MIS3 of the outer Basque shelf.

Cytheropteron sp. 4. Very rare in the Recent Basque shelf.

Elofsonella sp. MIS3, deep bathyal Bay of Biscay.

Eucytherura? sp. Early Holocene of the inner shelf.

Hemicythere rubida (Brady, 1868). MIS3, deep bathyal Bay of Biscay.

Hemicythere sp. Early Holocene of inner shelf.

Krithe aff. pernoides (Bornemann, 1855). MIS2, upper bathyal Bay of Biscay.
Krithe pernoides sinuosa (Bornemann, 1855). MIS5 and early Holocene, deep bathyal Bay of Biscay.

Krithe trinidadensis Bold, 1958. MIS5 to MIS3, deep bathyal Bay of Biscay.

Legitimocythere sp. MIS5c, deep Bay of Biscay.

Leptocythere tenera (Brady, 1868) Sars, 1925. Early Holocene, inner Basque shelf.

Paracytheridea cuneiformis (Brady, 1886). Mid-late Holocene, inner Basque shelf.

Paracytherois productum Yasuhara, Okahashi \& Cronin, 2009. MIS4, MIS5b, deep Bathyal Bay of Biscay.

Paradoxostoma sp. 1. Recent, epibathyal Bay of Biscay.

Paradoxostoma sp. 2. Recent, epibathyal Bay of Biscay.

Paradoxostoma sp. 3. Recent, epibathyal Bay of Biscay.

Paradoxostoma sp. 4. Recent of the Basque shelf.

Pontocypris acuminata (G.W. Müller, 1894). Recent, Basque shelf.

Propontocypris intermedia (Brady, 1868). Recent, Landas shelf.

Propontocypris pirifera (G.W. Müller, 1894). Recent, Landas shelf.

Pseudocythere gr. caudata Sars, 1866. MIS3 to Recent, outer shelf and bathyal Bay of Biscay.

Pseudocythere calcarata (Seguenza, 1880). MIS2, deep bathyal Bay of Biscay.

Sarsicytheridea bradyi (Norman, 1865). MIS3, outer shelf.

\section{BIOSTRATIGRAPHY AND PALAEOECOLOGY}

Stratigraphic and ecologic ranges of the described 155 ostracod species are shown in Figure 10. Most of the records range from MIS3 to Recent. Records from MIS4, MIS5 are from deep bathyal core PP10-17 and are here included to complete depth records of many of the species from the Basque shelf. Holocene has been divided into early, mostly warm (Hypsythermic), and mid-late, mostly cold (Neoglacial). We only found 19 species living today in this basin.

Modern ostracod assemblages in the Basque shelf are regulated by the sediment-type, the amount of organic matter, the oxygen content and depth, and dominated by Costa runcinata, Pterygocythereis ceratoptera-jonesii, 
Ostracods Basque Basin

Actinocythereis dunelmensis (Norman, 1865)

Argilloecia acuminata G.W. Müller, 1894

Argilloecia aff. conoidea (Sars, 1923)

Argilloecia bensoni Barra, Aiello \& Bonaduce, 1996

Argilloecia sp. 1

Argilloecia sp. 2

Argilloecia sp. 3

Argilloecia sp. 4

Aurila convexa (Baird, 1850)

Aurila woutersi Horne, 1986

Australoecia cf. posteroacuta Coles \& Whatley, 1989

Basslerites teres (Brady, 1869)

Bosquetina tarentina (Baird, 1850)

Brunneostoma spp.

Buntonia (Quasibuntonia) radiatopora (Seguenza, 1880)

Buntonia sublatissima (Neviani, 1906)

Buntonia textilis Bonaduce, Ciampo \& Masoli, 1975

Bythocypris aff. affinis (Brady, 1886)

Bythocypris sp.

Bythocythere bradleyi Athersuch, Horne \& Whittaker, 1983

Bythocythere bradyi Sars, 1926

Bythocythere eugeneschornikovi Yasuhara, Okahasi \& Cronin, 2009

Bythocythere intermedia Elofson, 1938

Bythocythere zetlandica Athersuch, Horne \& Whittaker, 1983

Callistocythere curryi Horne, Lord, Robinson \& Whittaker, 1990

Callistocythere littoralis (G.W. Müller, 1894)

Carinocythereis carinata (Roemer, 1838

Carinocythereis $\mathrm{sp}$.

Carinocythereis whitei (Baird, 1850)

Caudites calceolatus (Costa, 1853)

Celtia quadridentata (Baird, 1850)

Cluthia keiji Neale, 1975

Costa runcinata (Baird, 1850)

Cuneocythere semipunctata (Brady, 1868)

Cushmanidea turbida (G.W. Müller, 1894)

Cythere lutea O.F. Müller, 1785

Cytherella alvearium Bonaduce, Ciampo \& Masoli, 1975

Cytherella lata Brady, 1880

Cytherella robusta Colalongo \& Pasini, 1980

Cytheridea acuminata? (Bosquet, 1852)

Cytheropteron crassipinatum Brady \& Norman, 1888

Cytheropteron dorsocostatum Whatley \& Masson, 1979

Cytheropteron hadriaticum Bonaduce, Ciampo \& Masoli, 1976

Cytheropteron pararcticum Whatley \& Masson, 1979

Cytheropteron cf. ruggierii Pucci, 1956

Cytheropteron vespertilio (Reuss, 1850) Brady, 1868

Cytheropteron aff. vespertilio (Reuss, 1850) Brady, 1868

Cytheropteron testudo Sars, 1870

Cytheropteron sp. 1

Cytheropteron sp. 2

Cytheropteron sp. 3

Cytheropteron sp. 4

Cytherura gibba? (O.F. Müller, 1785)

Echinocythereis aff. echinata (Sars, 1866)

Echinocythereis laticarina (Brady, 1868)

Elofsonella concinna (Jones, 1857)

Elofsonella sp.

Elofsonia pusilla (Brady \& Robertson, 1870)

Eucythere anglica Brady, 1868

Eucythere curta Ruggieri, 1975

Eucytherura complexa (Brady, 1867)

Eucytherura mistrettai Sissingh, 1972

Eucytherura? sp.

Finnmarchinella (Barentsovia) angulata (Sars, 1866)

Hemicythere rubida (Brady, 1868)

Hemicythere $\mathrm{sp}$.

Hemicythere villosa (Sars, 1866)

Hemicytherura aff. clathrata (Sars, 1866)

Hemicytherura hoskini Horne, 1981

Henryhowella sp.

Heterocyprideis sorbyana (Jones, 1857)

Heterocythereis albomaculata (Baird, 1838)

Jonesia aff. acuminata (Sars, 1866)

"Krithe" gr. bartonensis (Jones, 1857)

Krithe dolichodeira Bold, 1946

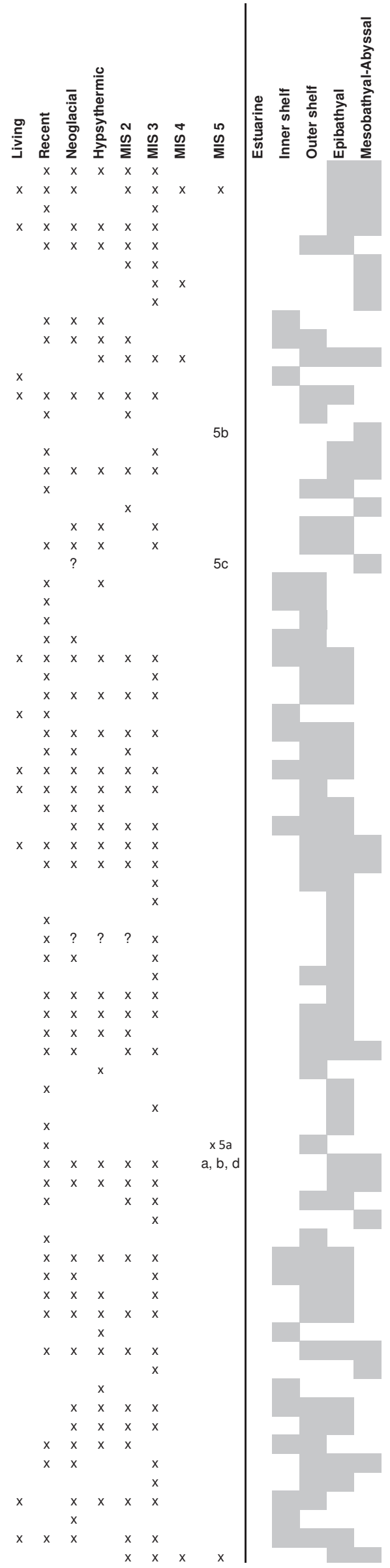


Krithe minima Coles, Whatley \& Moguilevsky, 1994 Krithe morkhoveni Bold, 1960

Krithe aff. pernoides (Bornemann, 1855)

Krithe gr. pernoides (Bornemann, 1855)

Krithe pernoides sinuosa (Bornemann, 1855)

Krithe trinidadensis Bold, 1958

Legitimocythere sp.

Leptocythere baltica Klie, 1929

Leptocythere castanea (Sars, 1866

Loxoconcha elliptica Brady, 1868

Leptocythere aff. lacertosa (Hirschmann, 1912)

Leptocythere macallana (Brady \& Robertson, 1869)

Leptocythere pellucida (Baird, 1850)

Leptocythere tenera (Brady, 1868) Sars, 1925

Loxoconcha rhomboidea (Fischer, 1855)

Loxoconcha sp. 1 aff. Loxoconcha linleyi Horne, 1982

Macrocypris minna (Baird, 1850)

Macrocypris tenuicauda Brady, 1880

Microcytherura fulva (Brady \& Robertson, 1874)

Neocytherideis subulata (Brady, 1868)

Neonesidea aff. corpulenta (G.W. Müller, 1894)

Neonesidea longevaginata (G.W. Müller, 1894)

Neonesidea mediterranea (G.W. Müller, 1894)

Oculocytheropteron nodosum (Brady, 1868)

Palmenella limicola (Norman, 1865)

Palmoconcha guttata (Norman, 1865)

Palmoconcha laevata (Norman, 1865)

Paracypris polita Sars, 1866

Paracytheridea cuneiformis (Brady, 1886)

Paracytherois flexuosa (Brady, 1867)

Paracytherois productum Yasuhara, Okahashi \& Cronin, 2009

Paracytherois sp. 1

Paracytherois sp. 2

Paradoxostoma aff. abbreviatum Sars, 1866

Paradoxostoma ensiforme Brady 1868

Paradoxostoma tenuissimum (Norman, 1869)

Paradoxostoma variabile (Baird, 1835)

Paradoxostoma sp. 1

Paradoxostoma sp. 2

Paradoxostoma sp. 3

Paradoxostoma sp. 4

Parakrithe dimorpha Bonaduce, Ciampo \& Masoli, 1975

Parakrithe sp. 1

Polycope frequens G.W. Müller, 1894, sensu Bonaduce et al., 1975

Polycope cf. reticulata (G.W. Müller, 1894)

Pontocypris acuminata (G.W. Müller, 1894)

Propontocypris intermedia (G. Brady, 1868).

Propontocypris pirifera (G.W. Müller, 1894)

Pseudocythere calcarata (Seguenza, 1880)

Pseudocythere caudata Sars, 1866

Pseudocythere gr. caudata Sars, 1866

Pseudopsammocythere similis (G.W. Müller, 1894)

Pterygocythereis ceratoptera (Bosquet, 1852)

Pterygocythereis jonesii (Baird, 1850)

Rabilimis mirabilis (Brady, 1868) Hazel, 1967

Rectotrachyleberis punctatissima punctatissima (Ruggieri, 1962)

Robertsonites cf. tuberculatus (Sars, 1866)

Sagmatocythere multifora (Norman,1865)

Sagmatocythere aff. multifora (Norman,1865)

Sagmatocythere variesculpta (Ruggieri, 1962)

Sagmatocythere aff. variesculpta (Ruggieri, 1962)

Sarsicytheridea bradyi (Norman, 1865)

Sclerochilus rudjakovi Athersuch \& Horne, 1987

Semicytherura acuminata (G.W. Müller, 1894)

Semicytherura angulata (Brady, 1868)

Semicytherura aff. S. angulata (Brady, 1868)

Semicytherura aff. nigrescens (Baird, 1838)

Semicytherura aff. simplex (Brady \& Norman, 1889) Yassini, 1969

Semicytherura cf. stilifera Bonaduce et al., 1976, sensu Cabral \& Loureiro, 2013

Semicytherura tela Horne \& Whittaker, 1980

Semicytherura undata (Sars, 1866)

Semicytherura sp. 1

Semicytherura sp. 2

Thaerocythere hoptonensis (Brady, Crosskey \& Robertson, 1874)

Trachyleberis? sp.

Urocythereis britannica Athersuch, 1977

Xestoleberis aff. dispar G.W. Müller, 1894

Xestoleberis aff. rubens Whittaker, 1978

Xestoleberis sp.
Semicytherura arcachonensis Yassini, 1969

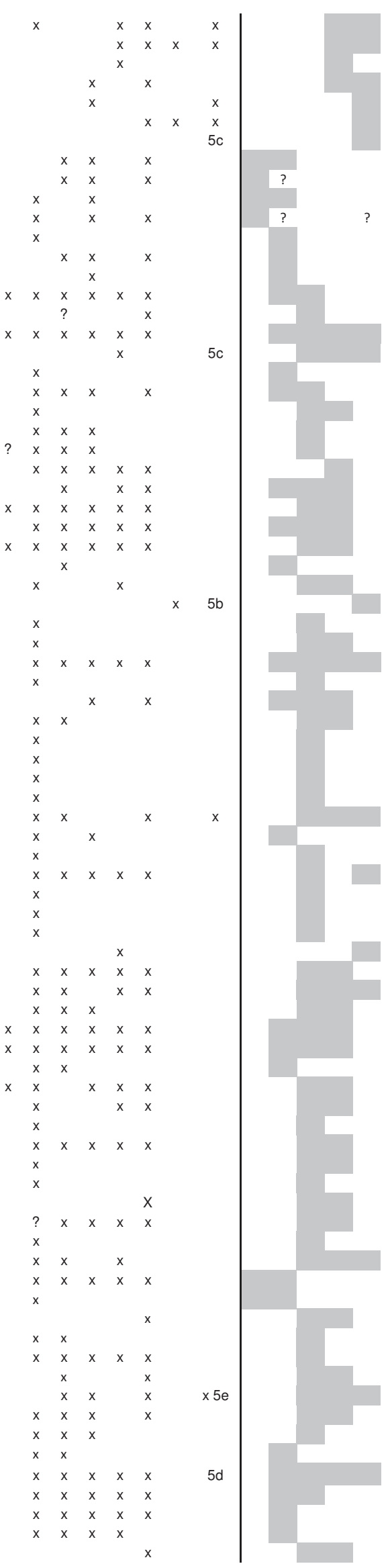

Figure 10. Alphabetic list of the 155 studied ostracod species from the Basque Basin. Occurrences in the interval MIS5 to Recent and ecological distributions are shown. 
Palmoconcha guttata, Carinocythereis carinata and Oculocytheropteron nodosum. In muddy sediment, $P$. guttata dominates in shallow waters $(<100 \mathrm{mwd})$ and $P$. jonesii in the outer shelf.

Several ecologic assemblages can be recognised at generic level in this basin, with a variable number of species (Fig. 10). Deep (bathyal) assemblages are characterised by species of the genera Cytheropteron (12 spp.), Krithe (8 spp.), Argilloecia (7 spp.), Buntonia (3 spp.), Bythocythere (3 spp.), Cytherella (2 spp.), Echinocythereis (2 spp.), Pseudocythere (2 spp.), Parakrithe (2 sp.), Australoecia (1 sp.), Finmarchinella (1 sp.), Hemicythere (1 sp.), Henryhowella (1 sp.), Legitimocythere (1 sp.), Macrocypris (2 spp.).

The outer shelf bears species of the genera Paradoxostoma (7 spp.), Semicytherura (7 spp.), Paracytherois (4 spp.), Sagmatocythere (4 spp.), Carinocythereis (3 spp.), Neonesidea (3 spp.), Bythocythere (2 spp.), Eucythere (2 spp.), Eucytherura (2 spp.), Palmoconcha (2 spp.), Polycope (2 spp.), Propontocypris (2 spp.), Pseudocythere (2 spp.), Costa (1 sp.), Cuneocythere (1 sp.).

Inner shelf assemblage contains Leptocythere (4 spp.), Aurila (2 spp.), Loxoconcha (2 spp.), Xestoleberis (2 spp.), Caudites (1 sp.), Celtia (1 sp.), Hemicytherura (1 sp.).

There are also present some representatives of outer estuarine ostracods: Leptocythere (3 spp.), Semicytherura (2 spp.), Loxoconcha (1 sp.).

Finally, we found several specimens of species (Cypria ophtalmica (Jurine), Ilyocypris gibba? (Ramdohr), Limnocythere inopinata (Baird), Pseudocandona sp.) typical of riverine-lacustrine environments that have been transported to the shelf by the rivers.

\section{CONCLUSIONS}

1) Taxonomy of 155 ostracod species have been characterised in the Late Quaternary of the Basque Basin by the first time.

2) Biostratigraphic repartitions of these species have been depicted for MIS5 to Recent interval.

3) Main (palaeo)ecologic assemblages have been recognised at generic level from the bathyal to coastal environments in this basin.

\section{ACKNOWLEDGEMENTS}

This work was supported by the Spanish Ministry of Economy and Competitiveness MINECO (OPERA project, ref. CTM2013- 48639-C2-1-R and CHIMERA project, ref. CTM2016-75411-R), and by the HAREA Coastal Geology
Research Group (EJ/GV, IT976-16) and Formation and Research Unit in Quaternary: Environmental Changes and Human Fingerprint (UPV/EHU, UFI11/09) projects. M. Cremer, EPOC, UMR5805, Bordeaux I University is thanked for all facilities with sampling cores used in this work. SEM pictures have been taken at SGIker service of the UPV/EHU. Editors and M.C. Cabral are acknowledged by the careful review inproving the manuscript.

\section{REFERENCES}

Alvarez Zarikian, C.A. 2009. Data report: late Quaternary ostracodes at IODP Site U1314 (North Atlantic Ocean). In: Proc. IODP, 303/306 (Channell, J.E.T., Kanamatsu, T., Sato, T., Stein, R., Alvarez Zarikian, C.A. \& Malone, M.J., and the Expedition 303/306 Scientists). College Station, TX (Integrated Ocean Drilling Program Management International, Inc.). doi: 10.2204/iodp. proc.303306.213.2009.

Alvarez Zarikian, C.A. 2015. Cenozoic bathyal and abyssal ostracods beneath the oligotrophic South Pacific Gyre (IODP Expedition 329 Sites U1367, U1368 and U1370). Palaeogeography, Palaeoclimatology, Palaeoecology, 419, 115-142; doi: 10.1016/j.palaeo.2014.07.024.

Aranki, J.F. 1987. Marine lower Pliocene ostracoda of southern Spain with notes on the Recent fauna. Bulletin of the Geological Institutions of the University of Uppsala, 13, 1-94.

Athersuch, J. 1976. On Sagmatocythere napoliana (Puri). A Stereo-Atlas Ostracod Shells, 3, 117-124.

Athersuch, J. 1977. The Genus Urocythereis (Crustacea: Ostracoda) in Europe, with particular reference to Recent Mediterranean species. Bulletin of the British Museum (Natural History), Zoology, 32, 247-283.

Athersuch, J. 1978. On Pterygocythereis jonesii (Baird). A Stereo-Atlas of Ostracod Shells, 5, 9-16.

Athersuch, J. 1982. Some ostracod genera formerly of the Family Cytherideidae Sars. In: Fossil and Recent Ostracods (eds. Bate, R.H., Robinson, E. \& Sheppard, L.M.). Ellis Horwood, Chichester, 231-275.

Athersuch, J. \& Horne, D.J. 1981. On Lindisfarnia guttata (Norman). A Stereo-Atlas of Ostracod Shells, 8, 117-124.

Athersuch, J. \& Horne, D.J. 1987. Taxonomy of the genus Sclerochilus Sars (Crustacea: Ostracoda) from British waters with a pictorial key. Zoological Journal of the Linnean Society, 91, 197-222; doi: 10.1111/j.10963642.1987.tb01509.x.

Athersuch, J. \& Whittaker, J.E. 1976a. On Loxoconcha elliptica Brady. A Stereo-Atlas of Ostracod Shells, 3, 99-106.

Athersuch, J. \& Whittaker, J E. 1976b. On Loxoconcha rhomboidea (Fischer). A Stereo-Atlas of Ostracod Shells, 3, 81-90

Athersuch, J. \& Whittaker, J E. 1979. On Heterocythereis albomaculata (Baird). A Stereo-Atlas of Ostracod Shells, $6,117-124$. 
Athersuch, J. \& Whittaker, J.E. 1980. On Callistocythere littoralis (G.W. Müller). A Stereo Atlas of Ostracod Shells, 7, 61-66.

Athersuch, J. \& Whittaker, J.E. 1987a. On Carinocythereis carinata (Roemer). A Stereo-Atlas of Ostracod Shells, 14, 97-102.

Athersuch, J. \& Whittaker, J.E. 1987b. On Carinocythereis whitei (Baird). A Stereo-Atlas of Ostracod Shells, 14, 103-110.

Athersuch, J., Horne, D.J. \& Whittaker, J.E. 1983. Some species of the ostracod genus Bythocythere Sars from British waters. Journal of Micropalaeontology, 2, 71-81; doi: $10.1144 / \mathrm{jm} \cdot 2 \cdot 1.71$.

Athersuch, J., Horne, D.J. \& Whitakker, J.E. 1989. Marine and Brackish water ostracods. In: Synopses of the British Fauna (New Series) (eds. Kermack, D.M. \& Barnes, R.S.K.). The Linnean Society of London, 43, 343 p.

Baird, W. 1835. List of Entomostraca found in Berwickshire. Transactions of the Berwickshire Naturalists' Club. 1, 95-100.

Baird, W. 1838. The Natural History of the British Entomostraca. Magazine of Zoology and Botany (London), 2, 132-144.

Baird, W. 1845. Arrangement of the British Entomostraca, with a list of species, particularly noticing those which have as yet been discovered within the bounds of the Club. Transactions of the Berwickshire Naturalists ' Club, 2, 145-158.

Baird, W. 1850. The Natural History of the British Entomostraca. Ray Society, London.

Barra, D., Aiello, G. \& Bonaduce, G. 1996. The genus Argilloecia Sars, 1866 (Crustacea: Ostracoda) in the Pliocene - Early Pleistocene of the M. San Nicola Section (Gela, Sicily). In: Proccedings of the 2nd European Ostracodologist's Meeting (ed. Keen, M.C.). University Glasgow, Scotland, 1993, 129-134.

Bate, R.H. 1972. Phosphatized ostracods with appendages from the Lower Cretaceous of Brazil. Palaeontology, 15, 379-393.

Blake, C.H. 1933. Order Ostracoda. In: Biological Survey of the Mount Desert Region (ed. Protecter, W.). Wistar Institute of Anatomy and Biology, Philadelphia, 5, 229. 241.

Bold van den, W.A. 1946. Contribution to the Study of Ostracoda with Special Reference to the Tertiary and Cretaceous Microfauna of the Caribbean Region. DeBussy, Amsterdam.

Bold van den, W.A. 1958. Ostracoda of the Brasso Formation of Trinidad. Micropaleontology, 4, 391-418; doi: $10.2307 / 1484268$

Bold van den, W.A. 1960. Eocene and Oligocene Ostracoda from Trinidad. Micropaleontology, 6, 145-196; doi: $10.2307 / 1484466$

Bonaduce, G., Ciampo, G. \& Masoli, M. 1976. Distribution of Ostracoda in the Adriatic Sea. Publicazioni della Stazione Zoologica di Napoli, 40, 1-154.

Bonaduce, G., Ruggieri, G., Russo, A. \& Bismuth, H. 1992. Late Miocene ostracods from the Ashtart 1 well (Gulf of
Gabes, Tunisia). Bollettino della Societa Paleontologica Italiana, 31, 3-93.

Bornemann, J.G. 1855. Die mikroskopische Fauna des Septarienthones von Hermsdorf bei Berlin. Zeitschrift der Deutschen Geologischen Gesellschaft, 7, 307-371.

Bosquet, J. 1852. Description des Entomostracés fossiles des Terrains Tertiaires de la France et de la Belgique. Mémoires Couronnés et Mémoires des Savants Étrangers, 24, 1-142.

Brady, G.S. 1866. On new or imperfectly known species of marine Ostracoda. Transactions of the Zoological Society of London, 5, 359-393.

Brady, G.S. 1867. Report on the Ostracoda dredged amongst the Hebrides. Reports of the British Association for the Advancement of Science, 36, 208-211.

Brady, G.S. 1868. A Monograph of the Recent British Ostracoda. Transactions of the Linnean Society of London, 26, 353-495.

Brady, G.S. 1869. Description of Ostracoda. In: Les Fonds de la Mer (eds. Folin, L.D. \& Périer, L.). Part 1, 155-159; http://www.biodiversitylibrary.org/item/108784.

Brady, G.S. 1878. A monograph of the Ostracoda of the Antwerp Crag. Transactions of the Zoological Society of London, 10, 379-409.

Brady, G.S. 1880. Report on the Ostracoda dredged by H.M.S. Challenger, during the years 1873-1876. Report on the Scientific Results of the Exploring Voyage of H.M.S. Challenger, Zoology, 1, 1-184.

Brady, G.S. 1886. Les Ostracodes nouveaux des explorations du travailleur et du Talisman. In: Les Fonds de la Mer, Étude Internationale sur les Particularités Nouvelles des Régions Sous-Marines (eds. Folin, L.D. \& Périer, L.). Paris 1881/1887, Chapitre 7.

Brady, G.S. 1898. On new or imperfectly known species of Ostracoda, chiefly from New Zealand. Transactions of the Zoological Society of London, 14, 429-452.

Brady, G.S. \& Norman, A.M. 1889. A monograph of the marine and fresh-water Ostracoda of the North Atlantic and of northwestern Europe. Section I: Podocopa. Scientific Transactions of the Royal Dublin Society, 4, 63-270.

Brady, G.S. \& Robertson, D. 1869. Notes of a Week's Dredging in the West of 1reland. Annals and Magazine of Natural History, 4, 3, 353-374.

Brady, G.S. \& Robertson, D. 1870. The Ostracoda and Foraminifera of tidal rivers. Annales Magazine of Natural History, 4, 6, 1-33.

Brady, G.S. \& Robertson, D. 1874. Contributions to the study of the Entomostraca IX. On Ostracoda taken amongst the Scilly Islands and on the anatomy of Darwinula stevensoni. Annals and Magazine of Natural History, Series, 4, 114-118.

Brady, G.S., Crosskey, H.W. \& Robertson, D. 1874. A monograph of the post-Tertiary Entomostraca of Scotland including species from England and Ireland. Annual Volumes (Monographs) of the Palaeontographical Society, London, 28, 1-232.

Brandão, S.N. \& Karanovic, I. 2015. Ecology, palaeontology and taxonomy of Echinocythereis Puri, 1954 (Crustacea: 
Ostracoda) with a focus on the North Atlantic species. Papers in Palaeontology, 1-25; doi: 10.1002/spp2.1018.

Brandão, S.N. \& Yasuhara, M. 2013. Challenging deepsea cosmopolitanism: taxonomic re-evaluation and biogeography of ' Cythere dasyderma Brady, 1880' (Ostracoda). Journal of Micropalaeontology, 32, 109-122; doi: 101144/jmpaleo2012-009.

Brandão, S.N., Angel, M.V., Karanovic, I., Perrier, V. \& Yasuhara, M. 2017. World Ostracoda Database. Accessed at http://www.marinespecies.org/ostracoda on 2017-06-26.

Breman, E. 1976. Five Ostracode species from Adriatic deep Sea Sediments. Proceedings of the Koninklijke Nederlandse Akademie van Wetenschappen, Series B, 79, 9-17.

Cabral, M.C. \& Loureiro, I.M. 2013. Overview of Recent and Holocene ostracods (Crustacea) from brackish and marine environments of Portugal. Journal of Micropalaeontology, 32, 135-159; doi: 10.1144/jmpaleo2012-019.

Cabral, M.C., Freitas, M.C., Andrade, C. \& Cruces, A. 2006. Coastal evolution and Holocene ostracods in Melides lagoon (SW Portugal). Marine Micropaleontology, 60, 181-204; doi: 10.1016/j.marmicro.2006.04.003doi:10.10 16/j.marmicro.2006.04.003.

Caralp, M., Klingebiel, A., Lamy, A., Latouche, C., Moyes, J. \& Vigneaux, M. 1968. Étude micropaleontologique, sedimentologique et geochimique de quelques carottes de sediments recents du Golfe de Gascogne. Bulletin de l'Institut de Géologie du Bassin d'Aquitaine, 50, 3-73.

Carbonel, P. 1971. Les ensembles fauniques d'Ostracodes récents de l'estuaire de la Gironde et du proche plateau continental. Relations avec les phénomènes hydrodynamiques. Intérêt dans la reconstitution des paléoenvironnements. Doctoral Thesis, Université de Bordeaux 1, $n^{\circ}$ 646, France.

Carbonel, P. 1973. Ensembles fauniques d'Ostracodes de Plateau continental du Golfe de Gascogne. Bulletin de l'Institut de Geologie de Bassin d'Aquitaine, 14, 83-87.

Carbonnel, G. 1966. Essai d'étude statistique à propos d'un nouveau genre d'ostracode Pseudopsammocythere. Revue de Micropaleontologie, 9, 50-54.

Ciampo, G. 1986. Ostracodi del limite Tortoniano/Messiniano in alcune sezioni italiane. Bollettino della Società Paleontologica Italiana, 24, 29-110.

Colalongo, M.L. \& Pasini, G. 1980. La Ostracofauna plio-pleistocenica della Sezione Vrica in Calabria (con considerazioni sul limite Neogene/Quaternario). Bolletino della Società Paleontologica Italiana, 19, 44-126.

Coles, G.P. \& Whatley, R.C. 1989. New Palaeocene to Miocene genera and species of Ostracoda from DSDP sites in the North Atlantic. Revista Española de Micropaleontologia, 21, 81-124.

Coles, G.P., Whatley, R.C. \& Moguilevsky, A. 1994. The ostracod genus Krithe from the Tertiary and Quaternary of the North Atlantic. Palaeontology, 37, 71-120.

Coles, G.P., Ainsworth, N.R., Whatley, C. \& Jones, R.W. 1996. Foraminifera and Ostracoda from Quaternary carbonate mounds associated with gas seepage in the Porcupine Basin, offshore western Ireland. Revista Española de Micropaleontología, 28, 113-151.
Coryell, H.N. \& Fields, S. 1937. A Gatun Ostracode fauna from Cativa, Panama. American Museum Novitates, 956, $1-18$.

Costa, O.G. 1853. Ostracodi. Paleontologia del Regno di Napoli, 3, 161-196.

Cronin, T.M. 1981. Paleoclimatic implications of Late Pleistocene marine ostracodes from the St. Lawrence lowlands. Micropaleontology, 27, 384-418; doi: $10.2307 / 1485193$.

Cronin, T.M. 1988. Paleozoogeography of postglacial ostracoda from Northeastern North America. In: The Late Quaternary Development of the Camplain Sea Basin (ed. Gadd, N.R.). Geological Association of Canada, Special Paper, 35, 125-144.

Cronin, T.M. 1991. Late Neogene marine Ostracoda from Tjörnes, Iceland. Journal of Paleontology, 65, 767-794; doi: 10.1017/S002233600003777X.

Cronin, T.M. \& Compton-Gooding, E.E. 1987. Cenozoic ostracoda from Deep Sea Drilling Project Leg 95 off New Jersey (Sites 612 and 613). In: Initial Reports of the Deep Sea Drilling Project, Washington (eds. Poag, C.W., Watts, A.B., Cousin, M., Goldberg, D., Hart, M.B., Miller, K.G., Mountain, G.S., Nakamura, Y., Palmer, A., Schiffelbein, P.A., Schreiber, B.C., Tarafa, M., Thein, J.E., Page, C.V. \& Wilkens, R.H.). U.S. Govt. Printing Office, 95, 439-451; doi: 10.2973/dsdp.proc.95.116.1987.

Cronin, T.M. \& Ikeya, N. 1987. Paleoclimatic significance of circumpolar Artic marine Ostracodes in the Pliocene and Quaternary of Japan. INQUA XII International Congress, Abstract Book, 151.

Cronin, T.M., Boomer, I., Dwyer, G. \& Rodríguez-Lázaro, J. 2002. Ostracoda and paleoceanography. In: The Ostracoda: Applications in Quaternary Research (eds. Holmes, J.A. \& Chivas, A.). American Geophysical Union (AGU), Geophysical Monograph, 131, 99-119.

Cronin, T., Demartino, D.M., Dwyer, G.S. \& RodríguezLázaro, J. 1999. Deep-Sea Ostracode Species Diversity: Response to late Quaternary Climate Change. Marine Micropaleontology, 37, 231-249; doi: 10.1016/S03778398(99)00026-2.

Cushman, J.A. 1906. Marine Ostracoda of Vineyard Sound and adjacent waters. Proceedings of the Boston Society of Natural History, 32, 359-385.

Dana, J.D. 1853. Tribe III: Cyproidea- Ostracoda. In: Crustacea. United States Exploring Expedition during the Years 1838, 1839, 1840, 1841, 1842, under the Command of Charles Wilkes, U.S.N., with Atlas of 96 plates. C. Sherman, Philadelphia. 13, 1277-1304.

Dickson, C. \& Whatley, R.C. 1995. Cytheropteron frigidum sp. nov. and some other species of this genus from the Quaternary and Recent. In: Ostracoda and Biostratigraphy (ed. Riha, J.). A.A. Balkema, Rotterdam/Brookfield, 283-289.

Didié, C. \& Bauch, H.A. 2000. Species composition and glacial-interglacial variations in the ostracode fauna of the northeast Atlantic during the past 200,000 years. Marine Micropaleontology, 40, 105-129; doi: 10.1016/ S0377-8398(00)00034-7. 
Doruk, N. 1973. On Costa punctatissima (Ruggieri). StereoAtlas of Ostracod Shells, 1, 253-256.

Elofson, O. 1938. Neue und wenig bekannte Cytheriden von der Schwedischen Westküste. Arkiv för zoologi, 30A, 1-22.

Elofson, O. 1941. Zur Kenntnis der marinen Ostracoden Schwedens mit besonderer Berucksichtigung des Skageraks. Zoologiska bidrag från Uppsala, 19, 217-534.

Faranda, C. \& Gliozzi, E. 2008. The ostracod fauna of the Plio-Pleistocene Monte Mario succession (Roma, Italy). Bollettino della Societa Paleontologica Italiana, 47, 215-267.

Faranda, C. \& Gliozzi, E. 2011. A revision of the "northern guest" Ostracoda (Crustacea) occurrence in the Quaternary of the Mediterranean area. Il Quaternario, 24, 75-92.

Faure, P. \& Guernet, C. 1988. Ludien marin de Château-Thierry, ostracodes et correlations stratigraphiques entre bassin de Paris (France) et bassin du Hampshire (Grande-Bretagne). Geobios, 21, 507-513.

Fischer, S. 1855. Beitrage zur Kenntnis der Ostracoden. Abhandlungen Bayerische Akademie der Wissenschaften, 7, 635-665.

Freiwald, A. \& Mostafawi, N. 1998. Ostracods in a coldtemperate coastal environment, Western Troms, Northern Norway: Sedimentary aspects and assemblages. Facies, 38, 255-274; doi: 10.1007/BF02537368.

Frenzel, P., Keyser, D. \& Viehberg, F.A. 2010. An illustrated key and (palaeo) ecological primer for Postglacial to Recent Ostracoda (Crustacea) in the Baltic Sea. Boreas, 39, 567575; doi: 10.1111/j.1502-3885.2009.00135.x.

Gemery, L., Cronin, T.M., Poirier, R.K., Pearce, C., Barrientos, N., O’Regan, M., Johansson, C., Koshurnikov, A. \& Jakobsson, M. 2017. Central Arctic Ocean paleoceanography from $\sim 50 \mathrm{ka}$ to present, on the basis of ostracode faunal assemblages from SWERUS 2014 expedition. Climate Past Discuss, 13, 1473-1489; doi: 10.5194/cp-2017-22, in review, 2017.

Gründel, J. 1967. Zur Großgliederung der Ordnung Podocopida G. W. Müller, 1894 (Ostracoda). Neues Jahrbuch für Geologie und Paläontologie, 6, 321-332.

Guernet, C., Lemeille, F., Sorel, D., Bourdillon, C., BergeThierry, C. \& Manakou, M. 2003. Les Ostracodes et le Quaternaire d'Aigion (golfe de Corinthe, Grèce). Revue de Micropaléontologie, 46, 73-93; doi: 10.1016/S00351598(03)00013-8.

Guillaume, M.C., Peypouquet, J.P. \& Tetart, J., 1985. Quaternaire et Actuel. In: Atlas des Ostracodes de France. (ed. Oertli, H.). Mémoires Elf-Aquitaine, Pau, 9, 337-377.

Hanai, T. 1957. Studies on the Ostracoda from Japan. 3Subfamily Cytherurinae G.W. Müller (emend. G.O. Sars) and Cytheropterinae, new subfamily. Journal of the Faculty of Science, Tokyo University, 2, 11, 11-36.

Hanai, T. 1970. Studies on the ostracod Subfamily Schizocytherinae Mandelstam. Journal of Paleontology, 44, 693-729.

Hartmann, G. 1964. Zur Kenntnis der Ostracoden des Roten Meeres. Kieler Meeresforschungen, 20 Sonderheft, 35-127.

Hartmann, G. 1974. Zur Kenntnis des Eulitorals der afrikanischen Westkueste zwischen Angola und Kap der Guten Hoffnung und der afrikanischen Ostkueste von Suedafrika und Mocambique unter besonderer Beruecksichtigung der Polychaeten und Ostracoden Teil 3: Die Ostracoden des (eds. Hartmann-Schroeder, U.G. \& Hartmann, G.). Mitteilungen aus dem Hamburgischen Zoologischen Museum und Institut, 69 (Ergaenz.), 229-521.

Hazel, J.E. 1967. Classification and distribution of recent Hemicytheridae and Trachyleberididae (Ostracoda) of Northeastern North America. U.S. Geological Survey Professional Paper, 564, 1-49.

Hirschmann, N. 1909. Beitrag zur Kenntnis der Ostracodenfauna des Finnischen Meerbusens. 1. Meddelanden af Societas pro Fauna et Flora Fennica, Helsingsfors, 35, 282-296.

Hirschmann, N. 1912. Beitrag zur Kenntnis der Ostrakodenfauna des finnischen Meerbusens. Zweite Mitteilung. Acta Societatis pro Fauna et Flora Fennica, $36,2,1-65$.

Hirschmann, N. 1916. Ostracods collected by N. M. Knipovitsch and S. A. Pavlovitsch in the Baltic Sea, Summer 1908. Ezhegodnik Zoologicheskogo Muzeya Imperatorskog Akademii Nauk, 20, 567-597.

Horne, D.J. 1981. On Hemicytherura hoskini Horne sp. nov. A Stereo-Atlas of Ostracod Shells, 8, 13-18.

Horne, D.J. 1982. On Loxoconcha linleyi Horne sp. nov. A Stereo-Atlas of Ostracod Shells, 9, 33-40.

Horne, D.J. 1986. On Aurila woutersi Horne sp. nov. A StereoAtlas of Ostracod Shells, 13, 33-38.

Horne, D.J. \& Kilenyi, T.I. 1981. On Lindisfarnia laevata (Norman). A Stereo-Atlas of Ostracod Shells, 8, 107-116.

Horne, D.J. \& Whittaker, J.E. 1980. On Semicytherura tela Horne \& Whittaker sp. nov. A Stereo-Atlas of Ostracod Shells, 7, 125-130.

Horne, D.J. \& Whittaker, J.E. 1985a. A revision of the genus Paradoxostoma Fischer (Crustacea, Ostracoda) in British waters. Zoological Journal of the Linnean Society, 85, 131-203; doi: 10.1111/j.1096-3642.1985.tb01502.x.

Horne, D.J. \& Whittaker, J.E. 1985b. On Eucythere anglica Brady. A Stereo-Atlas of Ostracod Shells, 12, 7-10.

Horne, D.J., Cohen, A. \& Martens, K. 2002. Taxonomy, morphology and Biology of Quaternary and living Ostracoda. In: The Ostracoda: Applications in Quaternary Research (eds. Holmes, J.A. \& Chivas, A.R.). American Geophysical Union, Geophysical Monograph, 131, 5-36.

Horne, D.J., Holmes, J., Rodríguez-Lázaro, J. \& Viehberg, F. (eds.) 2012. Ostracoda as proxies for Quaternary climate change. Developments in Quaternary Science, 17; doi: 10.1016/B978-0-444-53636-5.00018-4.

Horne, D.J., Lord, A.R., Robinson, J.E. \& Whittaker, J.E. 1990. Ostracods as climatic indicators in interglacial deposits or on some new and little-known British Quaternary Ostracoda. Courier Forschungsinstitut Senckenberg, 123, 129-140.

Howe, H.V. \& Chambers, J. 1935. Louisiana Jackson Eocene Ostracoda. Louisiana Geological Survey Geological Bulletin, 5, 1-65.

Howe, H.V., Hadley, W., et al. 1935. Ostracoda of the Arca zone of the Choctawhatchee Miocene of Florida. Geological 
Bulletin, State of Florida, State Board of Conservation, Florida Geological Survey, 13, 1-37.

Howe, R.C. 1963. Type saline bayou Ostracoda of Louisiana. Louisiana Geological Survey Geological Bulletin, 40, 1-62.

Huh, M. \& Whatley, R. 1997. New species of Miocene cytheracean Ostracoda from the Pohang Basin, SE Korea. Journal of Micropalaeontology, 16, 31-40; doi: 10.1144/ jm.16.1.31.

Jones, T.R. 1849. A monograph of the Entomostraca of the Cretaceous Formation of England. Palaeontographical Society of London Monography, 1-40.

Jones, T.R. 1857. A Monograph of the Tertiary Entomostraca of England. Palaeontographical Society of London Monography, 9, 1-68.

Jones, T.R. 1901. On some Carboniferous shale from Siberia. Geological Magazine (Decade 4), 8, 433-436.

Kaufmann, A. 1900. Über zwei neue Candona-Arten aus der Schweiz. Zoologischer Anzeiger, 23 (608), 131-133.

Keij, A.J. 1957. Eocene and Oligocene ostracoda of Belgium. Mémoires de l'Institut Royal des Sciences Naturelles de Belgique, 6 (23), 1-210.

Kempf, E.K. 1986, 1987, 1988 (and later supplements). Index and Bibliography of Marine Ostracoda, vols. 1-4. Sonderveroffentlichungen des Geologisches Institut der Universitat Koeln, nos. 50-53, 762, 712, 771 and 454 p.

Klie, W. 1929. Beitrag zur Kenntnis der Ostracoden der südlichen und westlichen Ostsee, der festländischen Nordseeküste und der Insel Helgoland. Zeitschrift für wissenschaftliche Zoologie, 134, 270-306.

Latreille, P.A. 1802. Genera Crustaceorum et Insectorum, Tomus I. Amand Koenig, Paris.

Lienenklaus, E. 1894. Monographie der Ostrakoden des nordwest-deutschen Tertiärs. Zeitschrift der Deutschen Geologischen Gesellschaft, 46, 158-268.

Maddocks, R.F. 1969. Recent ostracodes of the Family Pontocyprididae chiefly from the Indian Ocean. Smithsonian Contributions to Zoology, 7, 1-56; doi: 10.5479/si.00810282.7.

Maddocks, R.F. 1990. Living and fossil Macrocyprididae (Ostracoda). University of Kansas Paleontological Contributions Monograph, 2, 1-285.

Mandelstam, M.I. 1958. Novy Rody i Vidy Ostrakod (New ostracod genera and species). Trudy Vsesoyuznogo Neftyanogo Nauchno-Issledovatelskogo Geologo Razvedochnogo Instituta (VNIGRI), 115 (microfauna SSSR: 9), 232-299.

Mandelstam, M.I. 1959. Ostrakody iz otlozenij paleogena Srednej Azii. Mikrofauna SSSR, 10, 136, 442-525.

Martín-Rubio, M., Rodríguez-Lázaro, J. \& Pascual, A. 2004. Distribución areal y ecológica de las asociaciones de ostrácodos recientes en la marisma Victoria (Noja, Cantabria). Geogaceta, 36, 155-158.

Martín-Rubio, M., Elorza-Remón, M., Rodríguez-Lázaro, J. \& Pascual, A. 2006. Distribución areal y ecología de las asociaciones de ostrácodos recientes en la marisma Joyel (Cantabria). Geogaceta, 40, 187-190.

Martínez-García, B. 2012. Cambios oceanográficos y climáticos en el Sur del Golfo de Bizkaia durante el
Cuaternario final, detectados por medio de foraminiferos y ostrácodos. Doctoral Thesis, Universidad del País Vasco UPV/EHU (unpublished).

Martínez-García, B., Pascual, A. \& Rodríguez-Lázaro, J. 2013. The Ostracoda (Crustacea) of the Tina Menor estuary (Cantabria, southern Bay of Biscay): Distribution and ecology. Journal of Sea Research, 83, 111-122.

Martínez-García, B., Rodríguez-Lázaro, J., Pascual, A. \& Mendicoa, J. 2015. The "Northern guests" and other paleoclimatic ostracod proxies in the late Quaternary of the Basque Basin (S Bay of Biscay). Palaeogeography, Palaeoclimatology, Palaeoecology, 419, 100-114; doi: 10.1016/j.palaeo.2014.06.032.

Maybury, C. 1993. On Loxocorniculum multireticulatum Maybury sp. nov. A Stereo Atlas of Ostracod Shells, 20 (24), 101-104.

Meireles, R.P., Keyser, D. \& Ávila, S.P. 2014. The Holocene to Recent Ostracods of the Azores Archipelago (NE Atlantic): Systematics and Biogeography. Marine Micropaleontology, 112, 13-26; doi: 10.1016/j. marmicro.2014.08.002.

Mostafawi, N. \& Matzke-Karasz, R. 2006. Pliocene Ostracoda of Cephalonia, Greece.The unrevised species of Uliczny (1969). Revista Española de Micropaleontología, 38, 11-48.

Müller, G.W. 1893. Üeber Lebensweise und Entwicklungsgeschichte der Ostracoden. Sitzungsberichte der Koeniglich Preussischen Akademie der Wissenschaften zu Berlin, 23, 355-381.

Müller, G.W. 1894. Die Ostracoden des Golfes von Neapel und der angrenzenden Meeresabschnitte. Fauna und flora des golfes von Neapel und der angrenzenden MeeresAbschnitte herausgegeben von der zoologischen Station zu Neapel, 21, 1-404.

Müller, G.W. 1912. Crustacea: Ostracoda. In: Das Tierreich. Koeniglich Preußische Akademie der Wissenschaften zu Berlin, 1-434.

Müller, O.F. 1785. Entomostraca seu Insecta Testacea, quae in aquis Daniae et Norvegiae reperit, descripsit et iconibus illustravit. Lipsiae et Havniae, 1-135.

Nachite, D., Rodríguez-Lázaro, J., Martín-Rubio, M., Pascual, A. \& Bekkali, R. 2010. Distribution et écologie des associations d'ostracodes récents de l'estuaire de Tahadart (Maroc Nord-Occidental). Revue de Micropaléontologie, 53, 3-15; doi: 10.1016/j.revmic.2008.04.004.

Neale, J.W. 1973. Celtia gen. nov., a new genus of marine Ostracoda (Crustacea) from the Celtic Province and Neogene deposits. Revista Española de Micropaleontología, 5, 435-445.

Neale, J.W. 1974. Ostracod faunas from the Celtic Sea. Geoscience and Man Baton Rouge, 6, 81-98.

Neale, J.W. 1975a. On Cluthia keiji Neale sp. nov. A StereoAtlas of Ostracod Shells, 2-23, 141-148.

Neale, J.W. 1975b. On Celtia quadridentata (Baird). A StereoAtlas of Ostracod Shells, 2, 287 -294.

Neviani, A. 1906. Ostracodi delle sabbie postplioceniche di Carrubbare (Calabria). Bollettino della Società Geologica Italiana, 25, 185-216. 
Neviani, A. 1928. Di alcuni ostracodi raccolti sulle spiaggie di Bari e di Rimini. Atti della Pontificia Accademia delle Scienze- nuovi lincei, 81, 123-132.

Norman, A.M. 1862. Contributions to British Carcinology. II. On species of Ostracoda new to Great Britain. Annals and Magazine of Natural History, Series 3, 9, 43-55.

Norman, A.M. 1865. Report on the Crustacea of the deepsea dredging off the coast of Northumberland and Durham, 1862-1864. Natural History Transactions of Northumberland, Durham, and Newcastle-upon-Tyne. Tyneside Naturalists' Field Club, 1, 12-29.

Norman, A.M. 1869. Shetland final dredging report. Part II. On the Crustacea, Tunicata, Polyzoa, Echinodermata, Actinozoa, Hydrozoa, and Portifera. Report of the meeting of the British Association for the Advancement of Science, 38, 247-336.

Ozawa, H. 2004. Okhotsk Sea ostracods in surface sediments: depth distribution of cryophilic species relative to oceanic environment. Marine Micropaleontology, 53, 245-260; doi: 10.1016/j.marmicro.2004.06.002.

Pascual, A. 1990a. Utilización de los foraminíferos y ostrácodos para un mejor conocimiento del medio ambiente en los estuarios vizcaínos: aplicación a las rías de Guernica y de Bilbao. Doctoral Thesis, Universidad del País Vasco (unpublished).

Pascual, A. 1990b. Los ostrácodos actuales de la ría de Lekeitio. Kobie, XIX, 45-51.

Pascual, A. 1991. Ostracodes in Biscayan estuaries (Spain): their relationship with the environment. Cahiers de Micropaléontologie, 6, 5-16.

Pascual, A. \& Carbonel, P. 1992. Distribution and annual variations of Loxoconcha elliptica in the Gernika Estuary (Bay of Biscay). Geobios, 25, 495-503; doi: 10.1016/ S0016-6995(92)80077-Q.

Pascual, A., Rodríguez-Lázaro, J., Weber, O. \& Jouanneau, J.M. 2002. Late Holocene pollution in the Gernika Estuary (southern Bay of Biscay) evidenced by the study of Foraminifera and Ostracoda. Hydrobiologia, 475/476, 477-491; doi: 10.1023/A:1020316231441.

Pascual, A., Rodríguez-Lázaro, J., Martín, M., Jouanneau, J.M. \& Weber, O. 2008. A survey of the benthic microfauna (Foraminifera, Ostracoda) on the Basque Shelf (Southern Bay of Biscay). Journal of Marine Systems, 72, 35-63; doi: 10.1016/j.jmarsys.2007.05.015.

Pascual, A., Weber, O., Rodríguez-Lázaro, J., Jouanneau, J.M. \& Pujos, M. 1998. Le comblement de la ria de Gernika (Golfe de Gascogne) a l'Holocene terminal. Oceanologica Acta, 21, 263-269; doi: 10.1016/S0399-1784(98)80013-3.

Peypouquet, J.P. 1970. Les Ostracodes de la région de Capbreton. Intérêt écologique et paléoécologique. Thèse de 3 ème cycle de l'Université de Bordeaux I, France, $n^{\circ} 805$.

Peypouquet, J.P. 1977. Les ostracodes, indicateurs paléoclimatiques et paléogéographiques de quaternaire terminal (Holocene) sur le plateau continetal Sénégalais. In: Aspects of Ecology and Zoogeography of Recent and Fossil Ostracoda (eds. Löffler, H. \& Danielopol, D.L.). Dr.W. Junk B.V. Publishers, Hague, Netherlands, 369-394.
Pokorny, V. 1955. Contribution to the Morphology and Taxonomy of the Subfamily Hemicytherinae Puri. Acta Universitatis Carolinae Geologica, 2, 1-36.

Pucci, A. 1956. Ostracodi pleistocenici della valle del Tronto. Giornale di Geologica, Annali del Museo Geologico di Bologna, 25, 153-172.

Puri, H.S. 1952. Ostracode genus Cytherideis and its allies. Journal of Paleontology, 26, 902-914.

Puri, H.S. 1953a. The ostracod genus Hemicythere and its allies. Journal of the Washington Academy of Sciences, 43, 169-179.

Puri, H.S. 1953b. The ostracode genus Trachyleberis and its ally Actinocythereis. American Midland Naturalist, 49, 171-187.

Puri, H.S. 1954. Contribution to the study of the Miocene of the Florida Panhandle. Part 3: Ostracoda. Florida Geological Survey, Bulletin, 36, 215-345.

Puri, H.S. 1957. Henryhowella, new name for Howella Puri, 1956. Journal of Paleontology, 31, 982.

Puri, H.S. 1963. Preliminary notes on the Ostracoda of the Gulf of Naples. Experientia, 19, 368-372.

Puri, H.S. 1974. Normal pores and the phylogeny of Ostracoda. Geoscience and Man, 6, 137-151.

Puri, H.S. \& Hulings, N.C. 1976. Designation of lectotypes of some ostracods from the Challenger expedition. Bulletin of the British Museum (Natural History). Zoology, 29, 251-315.

Puri, H.S., Bonaduce, G. \& Malloy, J. 1965. Ecology of the Gulf of Naples. Pubblicazioni della Stazione Zoologica di Napoli, 33, 87-199.

Reuss, A.E. 1850. Die fossilen Entomostraceen des oesterreichischen Tertiaerbeckens. Naturwissenschftliche Abhandlungen, 3, 41-92.

Robinson, E. 1978. The Pleistocene. In: A stratigraphical Index of British Ostracoda (eds. Bate, R. \& Robinsosn, E.). Seel House Press, Liverpool, 451-472.

Rodríguez-Lázaro, J. \& Pascual, A. 1985. Estudio preliminar de los ostrácodos del estuario de la ría de Bilbao. Actas I Reunión del Cuaternario Ibérico, Lisboa, Abstract Book, 229-240.

Rodríguez-Lázaro, J., Martínez García, B. \& Pascual, A. 2011. Late Quaternary (60 ka) paleoclimatic record of the Basque Basin (S Bay of Biscay). Climate changes, bioevents and geochronology in the Atlantic and Mediterranean over the last 23 Myr. RCANS and RCMNS, Salamanca, Abstract Book, 210.

Rodríguez-Lázaro, J., Martín-Rubio, M., Pascual, A. \& Martínez, B. 2009. Ostracods as tracers of late Quaternary climatic oscillations in the southern Bay of Biscay. $16^{\text {th }}$ International Symposium on Ostracoda ISO16, Brasilia (Brasil), Abstract Book, 66.

Rodríguez-Lázaro, J., Pascual, A., Cacho, I., Varela, Z., Pena, L.D. 2017. Deep-sea benthic response to rapid climatic oscillations of the last glacial cycle in the SE Bay of Biscay. Journal of Sea Research, 130, 49-72; doi: 10.1016/j. seares.2017.06.002.

Roemer, F.A. 1838. Die Cytherinen des Molasse-Gebirges. Neues Jahrbuch fuer Mineralogie, Geognosie, Geologie und Petrefaktenkunde, 5, 514-519. 
Roemer, F.A. 1841. Die Versteinerungen des nordeutschen Kreidegebirges. Hahnsche Hofbuchhandlung, Hannover.

Ruggieri, G. 1950. Gli Ostracodi delle sabbie grigie quaternarie (Milazziano) di Imola (I). Giornale di Geologia, Bologna, serie 2, 21, 1-58.

Ruggieri, G. 1952. Nota preliminare sugli ostracodi di alcune spiaggie adriatiche. Note del Laboratorio di Biologia Marina di Fano, Annesso All'Istituto Zoologico dell'Universita di Bologna, 1, 57-63.

Ruggieri, G. 1953. Età e faune di un terrazzo marino sulla costa ionica della Calabria. Giornale di Geologia, serie 2, 23, 19-168.

Ruggieri, G. 1956. La subdivisione degli ostracodi gia compresi nel genere Cythereis proposta da Neviani nel 1928. Atti Societa Italiania di Scienze Natural, 95, 161-175.

Ruggieri, G. 1962. Gli Ostracodi marini del Tortoniano (Miocene medio-superiore) de Enna nella Sicilia orientale. Palaeontographia Italica, 56, 1-68.

Ruggieri, G. 1975. Sulla distribuzione geografica e stratigrafica del genere Falsocythere (Ostracoda, Podocopida). Bollettino della Societa Paleontologica Italiana, 12, 223-227.

Ruggieri, G. \& Russo, A. 1980. Due nuovi generi di ostracodi marini del Miocene superiore italiano. Bollettino della Societa Paleontologica Italiana, 19, 25-35.

Ruíz Muñoz, F. 1994. Los ostracodos del litoral de la Provincia de Huelva. Doctoral Thesis, Universidad de Huelva (unpublished).

Sars, G.O. 1866. Oversigt af Norges Marine Ostracoder. Forhandlinger $i$ Videnskabs-Selskabet $i$ Christiania, 1865 (1), 1-130.

Sars, G.O. 1869 (1870). Nye Dybvandscrustaceer fra Lofoten. Forhandlinger $i$ Videnskabs-Selskabet i Christiana, 1869, 147-174.

Sars, G.O. 1923. Ostracoda, parts 3 and 4. An Account of the Crustacea of Norway, with Short Descriptions and Figures of all the Species. Bergen Museum, 9, 33-72.

Sars, G.O. 1925. Ostracoda (parts 5-12). An Account of the Crustacea of Norway with Short Descriptions and Figures of all the Species. Bergen Museum, 9, 73-208.

Sars, G.O. 1926. Freshwater Ostracoda from Canada and Alaska. Report of the Canadian Arctic Expedition 1913$18,7,1-23$.

Sars, G.O. 1928. Ostracoda, 9. An Account of the Crustacea of Norway with Short Descriptions and Figures of all the Species. Bergen Museum, 9, 1-277.

Schlitzer, R. 2016. Ocean Data View. (Available at http://odv. awi.de).

Schornikov, E.I. 1974. Die beltischen Formengemeinschaften von der intertidalen Zone der Kurilen-Inseln. In: Die Pflanzen- und Tierwelt der Kurilen-Inseln - Institut Biologii Morja, Dal'nevostochnyy nauchnyy Tsentr Akademiya Nauk SSSR Sbornik Rabot, 5-74.

Schornikov, E.I. 1993. Ecosystem Research: Coastal Communities of Peter the Great Bay. USSR Academy of Sciences far East Branch, Vladivostok, 1-192.

Schornikov, E. 2015. Composition and distribution of the boreal-arctic ostracod Genus Heterocyprideis Elofson,
1941. Modern micropaleontology. Proceedings of the XVI All-Russian micropaleontological meeting (Kaliningrad), 111-115.

Schornikov, E. \& Zenina, M.A. 2006. Fauna of the benthic ostracods in the Kara, Laptev, and East-Siberian seas (based on materials collected in the POI FEB RAS expeditions). Russian Academy of Sciences far Eastern Branch. Proceedings of the Arctic Regional Center, Volume IV, 156-211.

Sciuto, F. \& Meli, A. 2015. Ostracod association from Pleistocene sediments along the Ionian coast of SE Sicily. Bollettino della Società Paleontologica Italiana, 54, 229241; doi: 10.4435/BSPI.2015.15.

Sciuto, F., Rosso, A., Sanfilippo, R. \& Di Martino, E. 2015. Ostracods from mid-outer shelf bottoms of the Ciclopi Islands Marine Protected Area (Ionian Sea, Eastern Sicily). Bollettino della Società Paleontologica Italiana, 54, 131145; doi: 10.4435/BSPI.2015.09.

Seguenza, G. 1880. Le formazioni terziarie nella provincia di Reggio (Calabria). Memorie della Classe di Scienze Fisiche Matematiche e Naturali della Regia Accademia del Lincei, 3, 1-445.

Sissingh, W. 1972. Late Cenozoic Ostracoda in the South Aegean Island Arc. Utrecht Micropaleontological Bulletins, 6, 1-187.

Stepanova, A., Taldenkova, E. \& Bauch, H.A. 2004. Ostracod species of the genus Cytheropteron from Late Pleistocene, Holocene and recent sediments of the Laptev Sea (Arctic Siberia). Revista Española de Micropaleontología, 36, 83-108.

Stepanova, A., Taldenkova, E., Simstich, J. \& Bauch, H. 2007. Comparison study of the modern ostracod associations in the Kara and Laptev seas: Ecological aspects. Marine Micropaleontology, 63, 111-142.

Swain, F.M. 1963. Pleistocene Ostracoda from the Gubik Formation, Arctic Coastal Plain, Alaska. Journal of Paleontology, 37, 798-834.

Swain, F.M. \& Gilby, J.M. 1974. Marine Holocene Ostracoda from the Pacific Coast of North and Central America. Micropaleontology, 20, 257-352.

Sylvester-Bradley, P.C. 1941. The shell structure of the Ostracoda and its application to their paleontological investigation. Annals and Magazine of Natural History, Series 11, 8, 1-33.

Sylvester-Bradley, P.C. 1948. Bathonian Ostracoda from the Boueti Beds of Langton Herring, Dorset. Geological Magazine, 85, 185-204.

Uffenorde, H. 1972. Oekologie und jahreszeitliche Verteilung Recent: er benthonischer Ostracoden des Limski Kanal bei Rovinj (noerdliche Adria). Goettinger Arbeiten zur Geologie und Palaeontologie, 13, 1-121.

Ulrich, E.O. \& Bassler, R.S. 1904. Systematic paleontology of the Miocene deposits of Maryland. Ostracoda. Maryland Geological Survey, 1, 98-130.

Wagner, C.W. 1957. Sur les Ostracodes du Quaternaire récent des Pays-Bas et leur utilisation dans l'étude géologique des dépots holocenes. Thèse, Université de Paris, A. 707, 1-259. 
Whatley, R. \& Coles, G. 1987. The Late Miocene to Quaternary Ostracoda of Leg 94, deep sea drilling project. Revista Española de Micropaleontología, 19, 33-97.

Whatley, R.C. \& Masson, D.G. 1979. The ostracod genus Cytheropteron from the Quaternary and Recent of Great Britain. Revista Española de Micropaleontología, 11, 223-277.

Whatley, R.C., Eynon, M. \& Moguilevsky, A. 1996. Recent Ostracoda of the Scoresby Sund fjiord system, east Greenland. Revista Española de Micropaleontología, 28, 5-24.

Whittaker, J.E. 1978. On Xestoleberis rubens Whittaker sp. nov. A Stereo-Atlas of Ostracod Shells, 5, 35-44.

Whittaker, J.E. \& Horne, D.J. 2009. Pleistocene. In: Ostracods in British Stratigraphy (eds. Whittaker, J.E. \& Hart, M.B.). The Geological Society of London, Special publications, 447-467; doi: 10.1144/TMS003.17.

Williamson, W.C. 1847. On some of the microscopical objects found in the mud of the Levant, and other deposits; with remarks on the mode of formation of calcareous and infusorial siliceous rocks. Memoirs of the Literary and Philosophical Society of Manchester (second series), 2, 1-128.

Wood, A.M. \& Whatley, R.C. 1997. The genera Muellerina Bassiouni, 1965 and Thaerocythere Hazel, 1967 from the Neogene of Northwest Europe. Journal of Micropalaeontology, 16, 1-18; doi: 10.1144/jm.16.1.1.

Yassini, I. 1969. Écologie des Associations d'Ostracodes du bassin d'Arcachon et du littoral Atlantique. Application à l'interpretation de quelques populations du Tertiare Aquitaine. Bulletin de l'Institut de Géologie du Bassin d'Aquitaine, 7, 1-288.

Yassini, I. 1979. The littoral system ostracodes from the Bay of Bou-Ismail, Algiers, Algeria. Revista Española de Micropaleontología, 11, 353-416.

Yasuhara, M. \& Okahashi, H. 2014. Quaternary deep-sea ostracode taxonomy of ocean drilling program site 980 , Eastern North Atlantic Ocean. Journal of Paleontology, 88, 770-785; doi: 10.1666/13-125.

Yasuhara, M. \& Okahashi, H. 2015. Late Quaternary deep-sea ostracod taxonomy of the eastern North Atlantic Ocean. Journal of Micropalaeontology, 34, 21-49; doi: 10.1144/ jmpaleo2013-022.

Yasuhara, M., Okahashi, H. \& Cronin, T. 2009. Taxonomy of Quaternary Deep-Sea Ostracods from the Western North Atlantic Ocean. Palaeontology, 52, 879-931; doi: 10.1111/j.1475-4983.2009.00888.x.

Yasuhara, M., Hunt, G., Okahashi, H. \& Brandão, S.N. 2015. Taxonomy of Deep-Sea Trachyleberidid, Thaerocytherid, and Hemicytherid Genera (Ostracoda). Smithsonian Contributions to Paleobiology, 96, 1-213.

Yasuhara, M., Grimm, M., Brandão, S.N., Jöst, A., Okahashi, H., Iwatani, H., Ostmann, A. \& Martínez Arbizu, P. 2014. Deep-sea benthic ostracodes from multiple core and epibenthic sledge samples in Icelandic waters. Polish Polar Research, 35, 341-360. 
